\title{
Article
}

\section{Interventions for treating depression after stroke}

Hackett, Maree, Anderson, Craig, House, Allan O and Xia, Jun

Available at https://clok.uclan.ac.uk/6821/

Hackett, Maree orcid iconORCID: 0000-0003-1211-9087, Anderson, Craig, House, Allan $O$ and Xia, Jun (2008) Interventions for treating depression after stroke. Cochrane Database of Systematic Reviews, - (4). pp. 1-95. ISSN 1469$493 X$

It is advisable to refer to the publisher's version if you intend to cite from the work. http://dx.doi.org/10.1002/14651858.CD003437.pub3

For more information about UCLan's research in this area go to

http://www.uclan.ac.uk/researchgroups/ and search for < name of research Group>.

For information about Research generally at UCLan please go to http://www.uclan.ac.uk/research/

All outputs in CLoK are protected by Intellectual Property Rights law, including Copyright law. Copyright, IPR and Moral Rights for the works on this site are retained by the individual authors and/or other copyright owners. Terms and conditions for use of this material are defined in the policies page.

\section{CLoK}

Central Lancashire online Knowledge www.clok.uclan.ac.uk

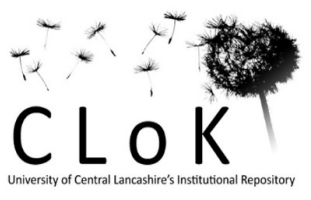




\title{
Interventions for treating depression after stroke (Review)
}

\author{
Hackett ML, Anderson CS, House A, Xia J
}

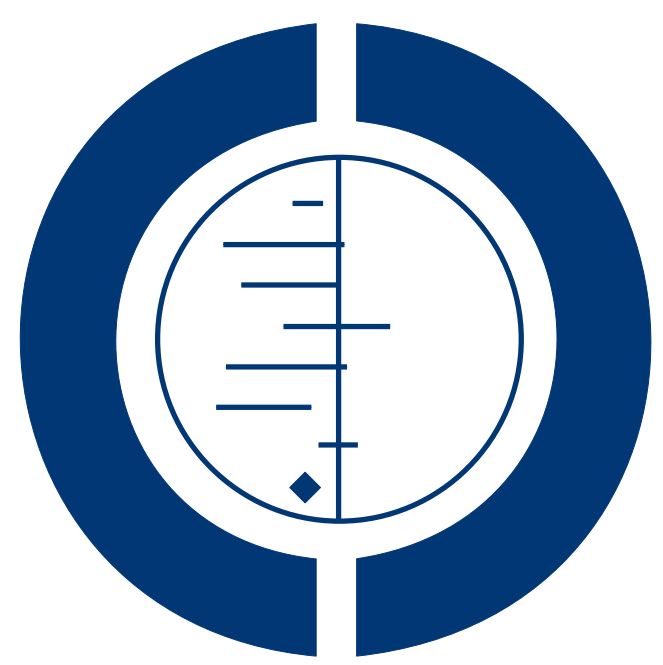

\section{THE COCHRANE COLLABORATION $^{\circledR}$}

This is a reprint of a Cochrane review, prepared and maintained by The Cochrane Collaboration and published in The Cochrane Library 2008, Issue 4

http://www.thecochranelibrary.com

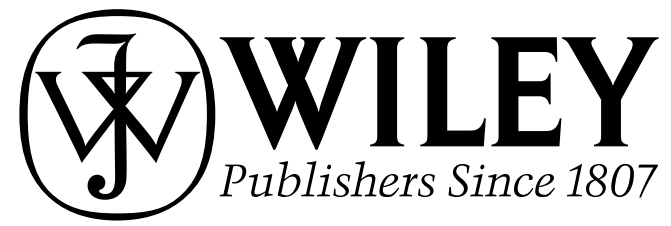

Interventions for treating depression after stroke (Review)

Copyright (C) 2008 The Cochrane Collaboration. Published by John Wiley \& Sons, Ltd. 
TABLE OF CONTENTS

HEADER . . . . . . . . . . . . . . . . . . . . . . . . . . . . . . . . 1

ABSTRACT .. . . . . . . . . . . . . . . . . . . . . . . . . . . . . . . . . . . . . . . . . . . . . . . . .

PLAIN LANGUAGE SUMMARY . . . . . . . . . . . . . . . . . . . . . . . . . . . . . . . . . . . . . 2

BACKGROUND . . . . . . . . . . . . . . . . . . . . . . . . . . . . . . . . . . . . . 2

OBJECTIVES . . . . . . . . . . . . . . . . . . . . . . . . . . . . . . . . . . . . . . . 3

METHODS . . . . . . . . . . . . . . . . . . . . . . . . . . . . . . . . . . . . . . 3

RESULTS . . . . . . . . . . . . . . . . . . . . . . . . . . . . . . . . . . . . . . . 6

DISCUSSION . . . . . . . . . . . . . . . . . . . . . . . . . . . . . . . . . . . . . . . . . . . 9

AUTHORS' CONCLUSIONS . . . . . . . . . . . . . . . . . . . . . . . . . . . . . . . 11

ACKNOWLEDGEMENTS . . . . . . . . . . . . . . . . . . . . . . . . . . . . . . . . . . . . . . . 11

REFERENCES . . . . . . . . . . . . . . . . . . . . . . . . . . . . . . . . . . . . . 12

CHARACTERISTICS OF STUDIES . . . . . . . . . . . . . . . . . . . . . . . . . . . . . . . . . . . . . 24

DATA AND ANALYSES . . . . . . . . . . . . . . . . . . . . . . . . . . . . . . . . . . . . . . . . . . . . . . 58

Analysis 1.1. Comparison 1 Pharmaceutical interventions versus placebo (antidepressants), Outcome 1 Depression: 1. Meeting study criteria for depression. . . . . . . . . . . . . . . . . . . . . . . . . . . .

Analysis 1.2. Comparison 1 Pharmaceutical interventions versus placebo (antidepressants), Outcome 2 Depression: 2. Average change in scores between baseline and end of treatment. . . . . . . . . . . . . . . . . . . . .

Analysis 1.3. Comparison 1 Pharmaceutical interventions versus placebo (antidepressants), Outcome 3 Depression: 3. Mean scores at end of treatment. $\quad . \quad$. . . . . . . . . . . . . . . . . . . . . . . . . . . . . . . . . . .

Analysis 1.4. Comparison 1 Pharmaceutical interventions versus placebo (antidepressants), Outcome 4 Depression: 4. Less than $50 \%$ reduction in scale scores...$\quad$. . . . . . . . . . . . . . . . . . . . . . . . . . . . . 66

Analysis 1.5. Comparison 1 Pharmaceutical interventions versus placebo (antidepressants), Outcome 5 Anxiety: 1. Meeting study criteria for anxiety. . . . . . . . . . . . . . . . . . . . . . . . . . . . . . . . . . . . . . . . . . . . .

Analysis 1.6. Comparison 1 Pharmaceutical interventions versus placebo (antidepressants), Outcome 6 Cognitive functioning: 1. Average change in scores between baseline and end of treatment. . . . . . . . . . . . . .

Analysis 1.7. Comparison 1 Pharmaceutical interventions versus placebo (antidepressants), Outcome 7 Cognitive functioning: 2. Mean scores at end of treatment. . . . . . . . . . . . . . . . . . . . . . . . . . . . .

Analysis 1.8. Comparison 1 Pharmaceutical interventions versus placebo (antidepressants), Outcome 8 Activities of daily living: 1 . Average change in scores between baseline and end of treatment. . . . . . . . . . . . . . . . .

Analysis 1.9. Comparison 1 Pharmaceutical interventions versus placebo (antidepressants), Outcome 9 Disability: 1. Average change in scores between baseline and end of treatment. . . . . . . . . . . . . . . . . . . . . .

Analysis 1.10. Comparison 1 Pharmaceutical interventions versus placebo (antidepressants), Outcome 10 Disability: 2. Mean scores at end of treatment.

Analysis 1.11. Comparison 1 Pharmaceutical interventions versus placebo (antidepressants), Outcome 11 Neurological function: 1. Average change in scores between baseline and end of treatment. . . . . . . . . . . . . . .

Analysis 1.12. Comparison 1 Pharmaceutical interventions versus placebo (antidepressants), Outcome 12 Neurological function: 2. Mean scores at end of treatment. . . . . . . . . . . . . . . . . . . . . . . . . . . . . . . .

Analysis 1.13. Comparison 1 Pharmaceutical interventions versus placebo (antidepressants), Outcome 13 Adverse events: 1. Death.

Analysis 1.14. Comparison 1 Pharmaceutical interventions versus placebo (antidepressants), Outcome 14 Adverse events: 2. All.

Analysis 1.15. Comparison 1 Pharmaceutical interventions versus placebo (antidepressants), Outcome 15 Adverse events: 3. Leaving the study early (including death).

Analysis 2.1. Comparison 2 Pharmaceutical interventions versus placebo (combination therapy), Outcome 1 Depression: 1. Average change in scores between baseline and end of treatment. . . . . . . . . . . . . . . . . . . .

Analysis 2.2. Comparison 2 Pharmaceutical interventions versus placebo (combination therapy), Outcome 2 Depression:

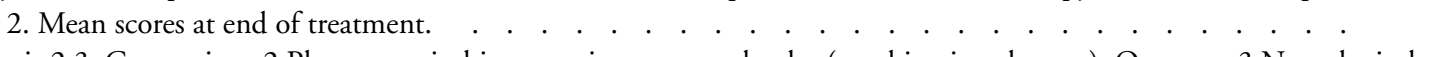

Analysis 2.3. Comparison 2 Pharmaceutical interventions versus placebo (combination therapy), Outcome 3 Neurological function: 1. Average change in scores between baseline and end of treatment. . . . . . . . . . . . . . . .

Analysis 2.4. Comparison 2 Pharmaceutical interventions versus placebo (combination therapy), Outcome 4 Neurological function: 2. Mean scores at end of treatment. . . . . . . . . . . . . . . . . . . . . . . . . . . . . . . . 76

Interventions for treating depression after stroke (Review)

Copyright @ 2008 The Cochrane Collaboration. Published by John Wiley \& Sons, Ltd. 
Analysis 2.5. Comparison 2 Pharmaceutical interventions versus placebo (combination therapy), Outcome 5 Adverse events: 1. All. . . . . . . . . . . . . . . . . . . . . . . . . . . . . . . . . .

Analysis 3.1. Comparison 3 Psychological interventions versus standard care and/or attention control, Outcome 1 Depression: Meeting study criteria for depression at end of treatment. . . . . . . . . . . . . . . .

Analysis 3.2. Comparison 3 Psychological interventions versus standard care and/or attention control, Outcome 2 Depression: 1. Average change in scores between baseline and end of treatment. . . . . . . . . . . . .

Analysis 3.3. Comparison 3 Psychological interventions versus standard care and/or attention control, Outcome 3 Depression: 2. Mean scores at end of treatment. . . . . . . . . . . . . . . . . . . . . . .

Analysis 3.4. Comparison 3 Psychological interventions versus standard care and/or attention control, Outcome 4 Psychological distress: 1. Average change in scores between baseline and end of treatment. . . . . . . . . .

Analysis 3.5. Comparison 3 Psychological interventions versus standard care and/or attention control, Outcome 5 Psychological distress: 2. Mean scores at end of treatment. . . . . . . . . . . . . . . . . . . .

Analysis 3.6. Comparison 3 Psychological interventions versus standard care and/or attention control, Outcome 6 Activities of daily living: 1 . Average change in scores from baseline to end of treatment. . . . . . . . . . . . .

Analysis 3.7. Comparison 3 Psychological interventions versus standard care and/or attention control, Outcome 7 Activities of daily living: 2 . Mean scores at end of treatment. . . . . . . . . . . . . . . . . . . . . . . . . . . .

Analysis 3.8. Comparison 3 Psychological interventions versus standard care and/or attention control, Outcome 8 Adverse events: 1 . Death. . . . . . . . . . . . . . . . . . . . . . . . . . . . . . . . . .

Analysis 3.9. Comparison 3 Psychological interventions versus standard care and/or attention control, Outcome 9 Adverse events: 2. All.

Analysis 3.10. Comparison 3 Psychological interventions versus standard care and/or attention control, Outcome 10 Adverse events: 3. Leaving the study early (including death) . . . . . . . . . . . . . . . . . . .

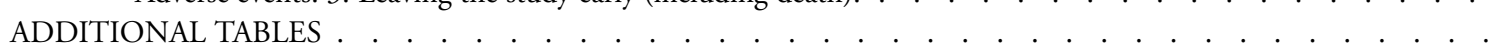

APPENDICES . . . . . . . . . . . . . . . . . . . . . . . . . . . . . . . . . . . . .

WHAT'S NEW . . . . . . . . . . . . . . . . . . . . . . . . . . . . . . . . . . . . .

HISTORY . . . . . . . . . . . . . . . . . . . . . . . . . . . . .

CONTRIBUTIONS OF AUTHORS . . . . . . . . . . . . . . . . . . . . . . . . . . . . . . . . . . .

DECLARATIONS OF INTEREST . . . . . . . . . . . . . . . . . . . . . . . . . . . . . . . . . . . . . . .

SOURCES OF SUPPORT . . . . . . . . . . . . . . . . . . . . . . . . . . . . . . . . . . . . . . . . . . .

INDEX TERMS 


\title{
[Intervention Review]
}

\section{Interventions for treating depression after stroke}

\author{
Maree L Hackett ${ }^{1}$, Craig S Anderson ${ }^{1}$, Allan House $^{2}$, Jun Xia ${ }^{3}$ \\ ${ }^{1}$ Department of Neurological and Mental Health, The George Institute for International Health, Sydney, Australia. ${ }^{2}$ Leeds Institute \\ of Health Sciences, University of Leeds, Leeds, UK. ${ }^{3}$ Cochrane Schizophrenia Group, Bridge House, Leeds, UK \\ Contact address: Maree L Hackett, Department of Neurological and Mental Health, The George Institute for International Health, \\ PO Box M201, Missenden Road, Sydney, NSW, 2050, Australia. mhackett@george.org.au.
}

Editorial group: Cochrane Stroke Group.

Publication status and date: New search for studies and content updated (conclusions changed), published in Issue 4, 2008.

Review content assessed as up-to-date: 25 May 2008.

Citation: Hackett ML, Anderson CS, House A, Xia J. Interventions for treating depression after stroke. Cochrane Database of Systematic Reviews 2008, Issue 4. Art. No.: CD003437. DOI: 10.1002/14651858.CD003437.pub3.

Copyright (C) 2008 The Cochrane Collaboration. Published by John Wiley \& Sons, Ltd.

\section{A B S T R A C T}

\section{Background}

Depression is an important consequence of stroke that impacts on recovery yet is often not detected or inadequately treated. This is an update of a Cochrane review first published in 2004.

\section{Objectives}

To determine whether pharmaceutical, psychological, or electroconvulsive treatment (ECT) of depression in patients with stroke can improve outcome.

\section{Search methods}

We searched the trials registers of the Cochrane Stroke Group (last searched October 2007) and the Cochrane Depression Anxiety and Neurosis Group (last searched February 2008). In addition, we searched the Cochrane Central Register of Controlled Trials (The Cochrane Library, Issue 1, 2008), MEDLINE (1966 to May 2006), EMBASE (1980 to May 2006), CINAHL (1982 to May 2006), PsycINFO (1967 to May 2006) and other databases. We also searched reference lists, clinical trials registers, conference proceedings and dissertation abstracts, and contacted authors, researchers and pharmaceutical companies.

\section{Selection criteria}

Randomised controlled trials comparing pharmaceutical agents with placebo, or various forms of psychotherapy or ECT with standard care (or attention control), in patients with stroke, with the intention of treating depression.

\section{Data collection and analysis}

Two review authors selected trials for inclusion and assessed methodological quality; three review authors extracted, cross-checked and entered data. Primary analyses were the prevalence of diagnosable depressive disorder at the end of treatment. Secondary outcomes included depression scores on standard scales, physical function, death, recurrent stroke and adverse effects.

\section{Main results}

Sixteen trials (17 interventions), with 1655 participants, were included in the review. Data were available for 13 pharmaceutical agents, and four trials of psychotherapy. There were no trials of ECT. The analyses were complicated by the lack of standardised diagnostic and outcome criteria, and differing analytic methods. There was some evidence of benefit of pharmacotherapy in terms of a complete remission of depression and a reduction (improvement) in scores on depression rating scales, but there was also evidence of an associated increase in adverse events. There was no evidence of benefit of psychotherapy. 


\section{Authors' conclusions}

A small but significant effect of pharmacotherapy (not psychotherapy) on treating depression and reducing depressive symptoms was found, as was a significant increase in adverse events. More research is required before recommendations can be made about the routine use of such treatments.

\section{PLAIN LANGUAGE SUMMARY}

\section{Interventions for treating depression after stroke}

Antidepressant drugs may be useful in treating depression after stroke, but also cause side effects. Depression is common after stroke and may be treated with antidepressant medication or psychological therapy. This review of 16 trials, including 1655 participants, found that antidepressant drugs may produce recovery or improve depression symptoms. However they also increase side effects. These drugs should be used with caution in people with persistent depressive symptoms after stroke, as little is known about the risks, especially of seizures, falls, and delirium. We found no evidence for the benefit of psychotherapy. Future research should include a broader group of stroke patients.

\section{B A C K G R O U N D}

Depressive and anxiety disorders are important sequelae of stroke. These mood disorders occur in at least one third of patients in the first year after onset of stroke, although estimates differ between trials due to varying definitions, populations, exclusion criteria, and the timing of assessments (Hackett 2005a). Inconsistent research findings are also due to the complexity of recognition, assessment and diagnosis of an underlying mood disorder associated with acute stroke, due to cognitive, language and other impairments. In addition, patients with stroke may experience a variety of behavioural syndromes that are more specific to brain injury, including indifference reaction, emotional lability, disinhibition, unawareness of illness (anosognosia) and difficulties with emotional expression (aprosody). In particular, much of the controversy surrounding 'stroke-associated depression' as a specific type of depressive syndrome hinges on concern about whether the tools normally used for the diagnosis of major depression and other depressive illnesses may misattribute features of ischaemic brain injury to depression (House 1987; Johnson 1991). Moreover, results will depend on whether subjects are categorised on the basis of psychiatric interview using standard diagnostic criteria such as the Diagnostic and Statistical Manual of Mental Disorders (e.g. DSM-IIIR, DSM-IV) (APA 1987; APA 1994) or psychiatric rating scales such as the Montgomery Åsberg Depression Rating Scale (MADRS) (Montgomery 1979), or based on self assessment using a rating scale of mood.

Although there is continued controversy about whether this illness is predominantly caused by physical factors (such as stroke lesion location) or by the patients' psychological response to stroke
(Carson 2000), evidence suggests that clinically diagnosed strokeassociated depression has a similar frequency and nature to depression among older people with other chronic illnesses (Burvill 1996; Burvill 1997; Sharpe 1990). While it was previously thought that the period of greatest risk appeared to be within the first few months of stroke onset (Burvill 1995a; Herrmann 1998; House 1991) this was not apparent in a systematic review of high-quality observational studies (Hackett 2005a). While some patients recover spontaneously, up to one third of patients have depression that persists during the first year or longer after the onset of stroke (Astrom 1996; Herrmann 1998). Patients with 'anxious depression' and those with more severe symptoms at presentation appear less responsive to treatment and have a worse long-term prognosis (Astrom 1996).

Evidence of a causal relationship between stroke-associated depression and adverse outcomes is complicated by potential confounding factors such as age, gender, social class, physical disability and co-morbid conditions. However, the evidence suggests that abnormal mood may impede rehabilitation (Parikh 1990; Sinyor 1986) by impairing physical and cognitive function (Robinson 1986), and contributing to stress on carers (Anderson 1995a). Furthermore, stroke-associated depression may also be associated with an increased risk of death (House 2001; Morris 1993b) including death by suicide (Stenager 1998). Depressive illness among older people, in general, is associated with greater morbidity and dependency, higher use of drugs and alcohol, increased use of healthcare resources, and poor compliance with treatment of co-morbid conditions (Katona 1995). 
Although depression may influence recovery and outcomes following stroke, many, perhaps most, patients do not receive effective treatment because their mood disorder is undiagnosed or inadequately treated. Ebrahim 1987a, for example, found that few patients with stroke-associated depression had been given antidepressants following discharge from hospital, while House et al (House 1989) reported that both general practitioners and hospital doctors had a passive attitude to therapy. While this invariably reflects the problems with the diagnosis of a 'significant' mood state among older people with disability, it may also reflect uncertainty among clinicians as to the balance of benefits and risks (including side effects) of therapies in this setting. Indirect evidence of the effectiveness of pharmacological and psychological treatments for depression (and anxiety) for older people in general, and in those with associated physical illness, are available in several published reviews (Gill 2000; Lima 2001; McCusker 1998; Mittmann 1997; Wilkinson 1997). However, because of the possibility that depression after stroke differs in important ways, it may be inappropriate to extrapolate these data to patients with stroke.

We undertook a systematic review of all randomised controlled trials (RCTs) (published and unpublished) of pharmaceutical agents, psychological therapies or electroconvulsive therapy (ECT) for the treatment of depression associated with stroke.

This is an update of a Cochrane review first published in 2004.

\section{O B J E C T I VES}

To determine whether treatment of depression in patients with stroke improves outcome in terms of reduction in the proportion of patients with diagnosable depressive disorder. Secondary objectives were to determine whether treatment of depression improves mood scores, physical functioning, and health related quality of life, and reduces dependency either in patients or principle caregivers. We also aimed to determine the safety of and adherence to such treatments.

\section{METHODS}

\section{Criteria for considering studies for this review}

\section{Types of studies}

We restricted the review to all relevant RCTs in patients with a clinical diagnosis of stroke, where a pharmaceutical agent, psychological therapy, or ECT, used for the treatment of depression, was compared with placebo or standard care. We excluded trials using a cross-over design, or in which two or more of the interventions were compared with each other rather than with a placebo or standard care group. There was no restriction on eligibility of RCTs on the basis of language, sample size, duration of follow up, or publication status.

Trials that met all the inclusion criteria, but in which no outcome data were available (either from the report of the trial or from the authors), could not contribute meaningfully to a pooled estimate of effect. These trials were regarded as 'drop outs' rather than ineligible, and are listed in an Additional Table (Table 1), to indicate that they have not been overlooked.

\section{Types of participants}

We defined stroke according to clinical criteria. These include cerebral infarction, intracerebral haemorrhage and 'uncertain' pathological subtypes. This review excludes trials of patients with subarachnoid haemorrhage (SAH) only, as this entity has a different natural history and management strategy from other stroke subtypes. However, we did include trials with mixed stroke subtypes, including small numbers of SAH patients. There were no restrictions on the basis of age, sex or other characteristic. Participants were required to have depression (diagnosed by psychiatric interview, mood scale, or treating clinician) on recruitment. We excluded trials with participants who were not depressed at recruitment, but that measured depression as the primary outcome at follow up. These trials were included in a review of interventions for preventing depression after stroke (Hackett 2008).

The diagnostic categories of depression considered were:

(1) depressive disorder, as defined by symptom scores on a standard screening instrument;

(2) major depression, as defined by the American Psychiatric Association Diagnostic and Statistical Manual of Mental Disorders (DSM-IIIR, DSM-IV; APA 1987; APA 1994) or similar diagnostic criteria;

(3) dysthymia or minor depression, as defined by DSM or other standard diagnostic criteria.

Trials that included mixed populations (such as stroke and head injury or other central nervous system disorders) were excluded unless separate results for the stroke patients could be identified. Patients were excluded if they were being treated primarily for a stroke-associated pain syndrome, even if depression was measured as a secondary outcome.

\section{Types of interventions}

We included any trial that attempted to evaluate the following. (1) A comparison between a pharmacological agent and placebo for the treatment of depression associated with stroke. Specific pharmacological agents included tricyclic antidepressants (for example nortriptyline, imipramine, and clomipramine), selective serotonin reuptake inhibitors (SSRIs) (for example fluvoxamine, fluoxetine, sertraline, citalopram and paroxetine), monoamine oxidase inhibitors (MAOIs) (for example moclobemide), and other 
antidepressant medications. Trials of an agent that was being evaluated for other reasons (for example neuroprotection or to facilitate neuro-regeneration) with a mood endpoint were excluded. We found no trials of psychostimulants (for example methylphenidate), mood stabilisers (for example lithium) or benzodiazepines. We found one trial of a combined preparation (Deanxit) which was included but analysed separately.

(2) A comparison between ECT and standard care for the treatment of depression associated with stroke. We found no trials of ECT. Any future trials will be included but analysed separately.

(3) A comparison between a psychological therapy and standard care for the treatment of depression associated with stroke. We included any psychological therapy that involved direct patientprofessional interaction. The content of the interaction could vary from counselling to specific psychotherapy provided it was directed at helping patients develop their social problem-solving skills and adjustment to the emotional impact of stroke. All interventions had to have a psychological component - talking, listening, support, advice; be based on a theory of talking therapy; be structured and timetabled as a talking therapy; and be delivered by somebody with some explicitly stated training and supervision in therapies. Exclusions included interventions whose sole purpose was to educate or to provide information, occupational therapy (including leisure therapy and other rehabilitation services), and visits from stroke support workers, unless there was a clearly defined psychological component.

\section{Types of outcome measures}

The primary analyses focused on the proportion of patients who could no longer be diagnosed according to diagnostic categories of depression that were applied by the trial authors at the end of the follow-up period (remission). These included:

(1) no longer meeting the criteria for depression or dysthymia as defined by DSM or similar standard diagnostic criteria;

(2) scoring below cut points for depressive disorder, as defined by symptom scores on standard rating scales.

Secondary outcomes were as follows.

(1) Depression, as measured on scales such as the Hamilton Depression Rating Scale (HDRS, Hamilton 1960), Montgomery Åsberg Depression Rating Scale (MADRS, Montgomery 1979), Geriatric Depression Scale (GDS, Gompertz 1993), Beck Depression Inventory (BDI, Beck 1961), and Hospital Anxiety and Depression Scale (HADS Depression sub-scale, Zigmond 1983).

(2) Psychological distress, as measured on composite scales such as the General Health Questionnaire (GHQ, Goldberg 1972).

(3) Anxiety, as measured on scales such as the Hamilton Anxiety Scale, Beck Anxiety Inventory, and the Hospital Anxiety and Depression Scale (HADS Anxiety sub-scale, Zigmond 1983).

(4) Cognition, as measured on scales such as the Mini-Mental State Examination (MMSE, Folstein 1975).
(5) Activities of daily living, as measured on scales such as the Barthel Index (BI, Mahoney 1965).

(6) Disability, as measured on scales such as the Functional Independence Measure (FIM, Deutsch 1997).

(7) Disadvantages of treatment were recorded as adverse events, grouped by death, all, and leaving the study early (including death).

Participants' reason for withdrawal from the trials was examined as a marker of acceptance.

We have identified the following additional endpoints for use in subsequent reviews, if measured.

- General health, as measured on composite scales such as the Nottingham Health Profile (NHP, Hunt 1986).

- Social activities, as measured on scales such as the Frenchay Activities Index (FAI, Wade 1985).

- HRQoL, as measured on scales such as the 36-item short form questionnaire (SF-36, Ware 1993).

- Proportion reporting dependence in self-care ADL on the modified Rankin Scale (mRS, Rankin 1957).

- Principal caregiver HRQoL and stress.

\section{Search methods for identification of studies}

See: 'Specialized register' section in Cochrane Stroke Group We searched the trials registers of the Cochrane Stroke Group (last searched by the Review Group Co-ordinator in October 2007) and the Cochrane Depression Anxiety and Neurosis Group (last searched February 2008). In addition, we searched the Cochrane Central Register of Controlled Trials (The Cochrane Library, Issue 1, 2008), MEDLINE (1966 to May 2006) (Appendix 1), EMBASE (1980 to May 2006), CINAHL (1982 to May 2006), PsycINFO (1967 to May 2006), Applied Science and Technology Plus (1986 to May 2006), Arts and Humanities Index (1991 to September 2002), Biological Abstracts (1969 to September 2002), BIOSIS Previews (2002 to May 2006), General Science Plus (1994 to September 2002), Science Citation Index (1992 to May 2006), Social Sciences Citation Index (1991 to May 2006), SocioFile (1974 to May 2006) and ISI Web of Science (2002 to February 2008). Biological Abstracts has now been superseded by BIOSIS Previews and ISI Web of knowledge includes the Arts and Humanities Index. We have not updated the searches on General Science Plus as this electronic database is not available for the current authors.

(1) We searched Dissertations and Theses (previously called Digital Dissertations), a database of abstracts from doctoral theses from within the United States, Canada, Scandinavia and the United Kingdom (1980 to August 2007).

(2) We searched the proceedings of the European Stroke Conferences (2000 to 2007) and the Stroke Society of Australasia Annual Scientific Meetings (1999 to 2007).

(3) In 2002 we contacted by letter several of the researchers active the area of stroke-associated mood disorders in the previous 10 
years. We identified these researchers by scanning author lists of the relevant published trials, reviews and conference proceedings. We asked them to verify that all relevant trials had been identified and also if they had knowledge of any other relevant published or unpublished trials. We have not contacted them for this review update.

(4) In 2002 we contacted major pharmaceutical companies by letter and asked if they knew of any relevant unpublished trials. We did not contact them for this update. However, we searched the online Clinical Trial Results and Clinical Trial Registries for Bristol-Myers Squibb, Eli Lilly, Forest, GlaxoSmithKline, Novartis, Organon, Pfizer, Roche, and Wyeth (to August 2007).

(5) We searched the online clinical trials and research registers www.strokecenter.org/trials, www.ClinicalTrials.gov, www.Clinicalstudyresults.org and www.anzctr.org.au (to August 2007). The compulsory registration of clinical trial protocols on these sites before recruitment of the first patient, enabled us to elect not to contact researchers and pharmaceutical companies.

(6) We reviewed chapters in books on the prevention and treatment of depression and management of stroke, including but not limited to, reviews of the management of stroke, books specifically directed at the treatment or prevention of depression, and those on stroke and old age.

\section{Data collection and analysis}

Two review authors $(\mathrm{MH}$ and $\mathrm{CH}$ ) reviewed all citations and discarded those that were irrelevant, based on the title of the publication and its abstract. In the presence of any suggestion that an article was possibly relevant, we retrieved the full-length article for further assessment. $\mathrm{MH}$ and $\mathrm{CH}$ independently selected the trials for inclusion in the review from the culled citation list. Potentially relevant Chinese articles were translated by JX. We resolved disagreements by discussion, and CA confirmed the final list and adjudicated any persisting differences of opinion.

\section{Data extraction}

$\mathrm{MH}, \mathrm{CH}$ and JX independently extracted, cross checked and entered the data on forms designed for the purpose. We discussed and resolved any discrepancies before we entered the data into the Review Manager software, RevMan 4.2.

We collected data on:

- the report: author, year, and source of publication;

- the study: sample characteristics, social demography, definition and criteria used for depression;

- the patients: stroke sequence (first ever versus recurrent), social situation, time elapsed since stroke onset, prior history of psychiatric illness, current neurological status, current treatment for depression, and a history of coronary artery disease;
- the research design and features: sampling mechanism, treatment assignment mechanism, adherence, non-response, and length of follow up;

- the intervention: type, duration, dose, timing, and mode of delivery;

- the effect size: sample size, nature of outcome, estimate and standard error.

To allow for intention-to-treat (ITT) analysis, we sought the data irrespective of their adherence, and regardless of whether the patients were subsequently deemed ineligible, or otherwise excluded from treatment or follow up.

We checked all the extracted data for agreement between review authors. We obtained missing information from the primary investigators whenever possible. To avoid introducing bias, this unpublished information was obtained in writing, on forms designed for the purpose, and entered into RevMan.

\section{Study characteristics}

Although there are a number of scales devised for assessing the quality of RCTs, there is no convincing evidence that complex and time-consuming scales are more effective than simple scales (Verhagen 2001). As we extracted data, we documented specific details about the following five points.

(1) Generation of the randomisation sequence: the method used; was the study described as randomised, and a genuine randomisation process described; was this adequate, inadequate, or unknown? If the randomisation was blocked, was the size of the blocks known to those entering patients. Adequate randomisation $=1$, inadequate/unknown randomisation $=0$.

(2) Concealment of the random sequence from those entering patients into the trial: the method used; was it one that ensured tamper-free concealment of allocation; was it adequate, inadequate or unknown? Concealed randomisation $=\mathrm{A}$, not concealed/unknown $=\mathrm{B}$, and insecure $=\mathrm{C}$.

(3) Who was blinded and how successful was blinding? Was the patient, health worker treating the patient, or the follow up raters blinded, and were attempts made to check blinding was successful?

(4) How many participants in each treatment group who were initially randomised were not included in the analysis? Was an ITT analysis possible on all participants from the published data (were there any exclusions from the trial after randomisation, or for cross over treatment groups)?

(5) How many patients were withdrawn from the trial, crossedover treatment groups, or were lost to follow up (including when the proportion of patients who were lost to follow up was less than $20 \%)$ ?

$\mathrm{MH}$ and CA independently assessed the methodological characteristics of each trial using the above checklist. The two review authors then met for a consensus meeting. They resolved disagreements by discussion, and a third review author $(\mathrm{AH})$ resolved any persisting differences of opinion. For each included trial, we de- 
scribed features that influenced the degree of bias, as well as differences in baseline prognostic variables that might invalidate the results. One or more of these variables could be used to undertake sensitivity analyses in subsequent reviews.

\section{Statistical analysis}

The main outcome of interest was the proportion of participants who met the diagnostic, or scoring, categories for depression at the end of follow up. For all dichotomous outcomes, we calculated odds ratios (OR), with 95\% confidence intervals (CI) where appropriate using fixed-effect analyses.

For continuous outcomes, if ordinal scale data appeared to be approximately normally distributed or if the analysis suggested parametric tests were appropriate, we treated the outcome measures as continuous variables. If there were at least two trials that reported the same outcomes, we reviewed the data for appropriateness of pooling. If there was definite evidence of heterogeneity $\left(\mathrm{I}^{2}>50 \%\right)$, we explored the potential reasons for the differences by performing subgroup or sensitivity analyses. If the heterogeneity could not be explained, we combined the trials using random-effects analyses with cautious interpretation, or did not combine them at all.

We used the RevMan software (RevMan 4.2) where possible; we used Excel and SAS for other analyses.

\section{Subgroup and sensitivity analyses}

If there was definite evidence of heterogeneity, we explored potential reasons for the differences by performing subgroup analyses, sensitivity analyses, and meta-regression (Normand 1999). Where possible, we had planned to perform subgroup analyses to examine the impact of treatment type and duration, and of stroke severity. We were to undertake sensitivity analyses to explore the influence of date of publication, sample size, method of diagnosing depression, duration of follow up, high (greater than 20\%) number of drop outs, and blinded versus unblinded outcome assessors. The sensitivity of the combined estimate to individual trials was to be explored by leaving one study out, calculating the combined effect of the remaining trials, and comparing the results with the combined effect based on all the trials. If meta-analyses are undertaken in updates of this review, funnel plots will be used to detect the presence of publication bias and the Trim and fill technique will be used to determine whether our results are sensitive to publication bias (Duval 2000).

These were not completed for the current version of this review.

\section{Additional requested data}

We wrote to the authors of all newly included, ongoing and dropout studies requesting data that were unavailable, or ambiguous in the published articles. We received responses with additional data from authors of two new trials (Lai 2006a; Watkins 2007). In 2004 we received responses with regard to six trials (Andersen 1994;
Downes 1995; Fruehwald 2003; Lincoln 2003; Murray 2002; Reding 1986, Towle 1989). We received no response from the remaining authors. We also wrote to all pharmaceutical companies known to produce, or have a licence to produce, antidepressants in 2004. We received nine replies identifying no new trials.

\section{R E S U L T S}

\section{Description of studies}

See: Characteristics of included studies; Characteristics of excluded studies; Characteristics of ongoing studies.

Seven new trials (Jiang 2001a; Lai 2006a; Ponzio 2001; Rampello 2005; Watkins 2007; Yang 2002; Zhao 2004) have been included since the previous published version of this review resulting in 16 included trials (17 interventions), with 1655 participants at entry, for inclusion (Andersen 1994; Fruehwald 2003; Jiang 2001a; Jiang 2001b; Lai 2006a; Lincoln 2003; Lipsey 1984; Murray 2002; Ohtomo 1991; Ponzio 2001; Rampello 2005; Reding 1986; Towle 1989; Watkins 2007; Wiart 2000; Yang 2002; Zhao 2004). Another eight trials require more information before we decide on inclusion or not. Lincoln 2003 compared an active treatment with an attention-control (the time spent by participants in the treatment group with a trained therapist was controlled in the attention-control group by participants spending an equal amount of time in focused conversation), as well as a control (standard care) group. We combined data from the attention-control and control group, and compared this with data for the treatment group. Jiang 2001a compared two active treatment arms with a placebo arm. We compared data from both treatment arms (Jiang 2001a; Jiang 2001b) with data from half the number of participants in the placebo arm and presented the results as two separate trials. More detailed information is provided in Characteristics of included studies.

We identified nine additional trials (Choi-Kwon 2006; Downes 1995; Graffagnino 2003; Isenberg 2000; Mauri 1988; Meara 1998; Ohtomo 1985; Xie 2003; Zhou 2004) that met the inclusion criteria for this review. However, no outcome data were available (unpublished data only, Downes 1995; Graffagnino 2003; Isenberg 2000; data not presented by treatment group or in a suitable format, Choi-Kwon 2006; Mauri 1988; Meara 1998; requires translation, Ohtomo 1985, or method of assessment of mood unclear Xie 2003; Zhou 2004). These trials are considered 'drop outs' and more detailed information on these trials is provided in Table 1. Another three trials (Graven 2008; Mitchell 2002; Thomas 2007) are currently ongoing.

A total of 167 trials were excluded. In 93 trials there was no placebo (pharmaceutical trials) nor usual care (psychotherapy trials) comparison arms, and in 55 the intervention did not meet the review 
criteria. The remaining trials were excluded for the variety of reasons listed.

\section{Participants}

\section{Sociodemography}

The mean age of participants ranged from 60 to 78 years. Six trials had balanced proportional frequencies of males and females ( Lincoln 2003; Lipsey 1984; Ponzio 2001; Rampello 2005; Reding 1986; Watkins 2007); four had more males in the control group (Andersen 1994; Fruehwald 2003; Jiang 2001a; Jiang 2001b), and five had more males in the active treatment group (Murray 2002; Towle 1989; Wiart 2000; Yang 2002; Zhao 2004), with the percentage of males ranging from $30 \%$ to $71 \%$. The proportion of males was unknown in two trials (Lai 2006a; Ohtomo 1991).

\section{Stroke details}

Six trials included participants with stroke due to intracerebral haemorrhage as well as cerebral infarction, five specified the diagnoses was made on the basis of a combination of standard clinical and CT criteria (Andersen 1994; Fruehwald 2003; Lipsey 1984; Rampello 2005; Wiart 2000), with the frequency of CT reported at $100 \%$ (Yang 2002 did not specify the method of diagnosis). Five trials included all stroke subtypes (Lincoln 2003; Murray 2002; Reding 1986; Towle 1989; Watkins 2007) with two reporting a CT rate of 100\% (Murray 2002; Watkins 2007), one trial included only cases of cerebral infarction (Ohtomo 1991) and five did not specify stroke details (Jiang 2001a; Jiang 2001b; Lai 2006a; Ponzio 2001; Zhao 2004).

\section{Recruitment time window}

The average time from stroke onset to entry into trials ranged from 'within a few days' (Fruehwald 2003) to 25 months (Towle 1989). Six trials included patients within one month of stroke onset (Andersen 1994; Fruehwald 2003; Lipsey 1984; Murray 2002; Watkins 2007; Wiart 2000). The time window from stroke onset to randomisation was wide (several months to more than two years) for seven trials (Andersen 1994; Lincoln 2003; Lipsey 1984; Murray 2002; Rampello 2005; Towle 1989; Yang 2002) and narrow (several days to several weeks) for four trials (Fruehwald 2003; Reding 1986; Watkins 2007; Wiart 2000). One trial (Towle 1989) specifically excluded patients with a stroke onset of less than one year from randomisation. Details of the time window for entry are uncertain for three trials (Lai 2006a; Ohtomo 1991; Ponzio 2001).

\section{Exclusion criteria}

Nine trials employed criteria that excluded patients with varying degrees of communication and/or cognitive difficulties and/ or other co-existing conditions that would interfere with outcome assessments or participation in the treatment regimens (Andersen 1994; Fruehwald 2003; Lipsey 1984; Murray 2002; Ponzio 2001; Rampello 2005; Watkins 2007; Wiart 2000; Zhao 2004). Other specific reasons for exclusion included: a history of depression in the last year (Andersen 1994) or previous five years (Lincoln 2003); on antidepressant medication (Andersen 1994; Jiang 2001a; Jiang 2001b; Lipsey 1984; Murray 2002) or receiving psychotherapy (Ponzio 2001; Watkins 2007); concurrent psychiatric illness (Murray 2002; Ponzio 2001; Rampello 2005; Wiart 2000); any contraindication to the study treatment (Lipsey 1984; Ponzio 2001; Wiart 2000) or where there was concurrent use of antiarrhythmic medication (Reding 1986); a history of myocardial infarction within the previous month (Murray 2002; Reding 1986); a stroke in the year prior to randomisation (Towle 1989); inability to speak English, blindness or deafness (Lincoln 2003); living outside the specific locality (Lincoln 2003; Watkins 2007); living in a hospital or in residential care (Towle 1989); and substance dependency (Ponzio 2001; Rampello 2005). Details are unclear for three trials (Lai 2006a; Ohtomo 1991; Yang 2002).

\section{Setting}

Six trials recruited patients from outpatient clinics or from home after they had been discharged from hospital (Lincoln 2003; Ponzio 2001; Rampello 2005; Towle 1989; Yang 2002; Zhao 2004); six trials recruited only inpatients soon after stroke onset (Fruehwald 2003; Jiang 2001a; Jiang 2001b; Lai 2006a; Reding 1986; Watkins 2007); and three trials used mixed inpatient and outpatient sources of patients (Andersen 1994; Lipsey 1984; Murray 2002). Details are unclear for two trials (Ohtomo 1991; Wiart 2000).

\section{Interventions}

Twelve trials assessed 13 pharmacological interventions (Andersen 1994; Fruehwald 2003; Jiang 2001a; Jiang 2001b; Lai 2006a; Lipsey 1984; Murray 2002; Ohtomo 1991; Ponzio 2001; Rampello 2005; Reding 1986; Wiart 2000; Yang 2002), and four assessed psychological interventions (Lincoln 2003; Towle 1989; Watkins 2007; Zhao 2004). Results from these trials are presented and discussed separately.

\section{Pharmacotherapy}

Among the trials of pharmacological treatments, seven trials compared an SSRI (citalopram, Andersen 1994; fluoxetine, Fruehwald 2003; Wiart 2000; paroxetine Lai 2006a; Ponzio 2001; Yang 2002; sertraline Murray 2002) against placebo; two trials compared a 
tricyclic antidepressant (amitriptyline, Jiang 2001a; nortriptyline, Lipsey 1984) against placebo; and other treatments with antidepressant effects were used in four trials (deanxit Jiang 2001b, aniracetam Ohtomo 1991, reboxetine Rampello 2005, trazodone Reding 1986). Five trials used a flexible dose regimen, with a lower dose in older people and/or dose escalation for persistently elevated mood scores during follow up (Andersen 1994; Fruehwald 2003; Jiang 2001a; Lipsey 1984; Murray 2002; Reding 1986). Six trials (Jiang 2001b; Lai 2006a; Ohtomo 1991; Ponzio 2001; Rampello 2005; Wiart 2000; Yang 2002) used a fixed dose. The duration of treatment was generally short, ranging from four to six weeks (Andersen 1994; Lipsey 1984; Reding 1986; Wiart 2000) to 12 weeks (Fruehwald 2003; Lai 2006a; Ohtomo 1991) to 16 weeks (Rampello 2005; Yang 2002). Murray 2002, Jiang 2001a and Jiang $2001 \mathrm{~b}$ provided treatment with a target duration of 26 weeks.

\section{Psychotherapy}

The forms of psychotherapy included problem-solving therapy with counselling delivered by social workers (Towle 1989), more structured cognitive behavioural therapy (CBT) delivered by nurses (Lincoln 2003), motivational interviewing (MI) delivered by nurses and non-clinical psychologists (Watkins 2007), and a supportive psychological intervention including education delivered by special personnel (Zhao 2004). The frequency and duration of sessions was individually tailored to the needs of the patient in three trials, so that the duration of treatment ranged from daily, less than 30 minute, sessions over four weeks (Zhao 2004), seven to 10 one-hour sessions over three months (Lincoln 2003), to four to six months (Towle 1989). In the most recent trial (Watkins 2007) all patients received up to four individual sessions of 30 to 60 minutes over four weeks (one per week). Three trials used standard care as the control comparison (Towle 1989; Watkins 2007; Zhao 2004) and the other used both a standard care control and an attention-control group (Lincoln 2003).

\section{Depression criteria}

A wide variety of criteria and methods were used to diagnose depression in the included trials: eight trials included patients who had high scores only on standard depression scales such as the HDRS (Jiang 2001a; Jiang 2001b; Lai 2006a; Yang 2002; Zhao 2004 with cutpoint scores varying from 6 (Lai 2006a) to 20 (Rampello 2005)), the MADRS (cutpoint of 18 Ponzio 2001) and either the WDI (cutpoint 17) or GHQ-28 (cutpoint 9, Towle 1989), or the GHQ-28 alone (cutpoint 4, Watkins 2007); two trials included patients with depressive illness diagnosed by psychiatric interview using standard psychiatric criteria (Lipsey 1984; Reding 1986); five trials used a combination of psychiatric interview and high scores on a depression scale (Fruehwald 2003, HDRS cutpoint 15; Lincoln 2003, BDI cutpoint 10, WDI cutpoint 18; Murray 2002, MADRS cutpoint 9; Rampello 2005,
HDRS cutpoint 20, BDI cutpoint 15; Wiart 2000, MADRS cutpoint 19); and one trial used a transformation of symptom domain scores from a standard depression scale (HDRS) to derive a DSM-III-R diagnosis of depression (Andersen 1994). The remaining trial included patients based on the 'physician's impression’ (Ohtomo 1991).

\section{Outcome measures}

\section{Depression}

Eight assessment scales were used to assess mood or assess change in mood at the end of treatment in nine trials. The most commonly used measure was the HDRS (Andersen 1994; Fruehwald 2003; Jiang 2001a; Jiang 2001b; Lai 2006a; Lipsey 1984; Rampello 2005; Yang 2002; Zhao 2004). Seven trials used two or more scales to assess abnormal mood or depression (Fruehwald 2003; Lincoln 2003; Lipsey 1984; Ponzio 2001; Rampello 2005; Towle 1989; Watkins 2007), one trial determined depression by psychiatric interview and a scale (Reding 1986) and one relied on physician impression (Ohtomo 1991).

\section{Additional outcomes}

A wide variety of additional measures were used in the trials (see Characteristics of included studies). Most trials only presented selected outcome data. Only six trials presented data from all questionnaires listed as being administered (Jiang 2001a; Jiang 2001b; Ponzio 2001; Towle 1989; Watkins 2007; Wiart 2000). Adverse event data were often not reported or reported poorly.

\section{Risk of bias in included studies}

\section{Generation and concealment of randomisation sequence}

Six trials used an appropriately generated and clearly concealed randomisation procedure (Andersen 1994; Fruehwald 2003; Lincoln 2003; Murray 2002; Towle 1989; Watkins 2007). The randomisation sequence appeared to be appropriately generated in nine trials (Andersen 1994; Fruehwald 2003; Lincoln 2003; Lipsey 1984; Murray 2002; Rampello 2005; Reding 1986; Towle 1989; Watkins 2007), however, not all trials described adequate concealment of allocation (Jiang 2001a; Jiang 2001b; Lai 2006a; Lipsey 1984; Ohtomo 1991; Ponzio 2001; Rampello 2005; Reding 1986; Wiart 2000; Yang 2002; Zhao 2004). 


\section{Blinding of participants and outcome assessors}

Four of the pharmacotherapy trials used an unequivocal doubleblinded outcome assessment for all patients (Fruehwald 2003; Lipsey 1984; Murray 2002; Reding 1986). Four trials stated a double-blind method but did not state who was blinded (Andersen 1994; Ohtomo 1991; Ponzio 2001; Wiart 2000) and in one trial the outcome assessor was not blinded (Rampello 2005). Three psychotherapy trials used single (assessor) blinded outcome assessment (Lincoln 2003; Towle 1989; Watkins 2007), details were unclear for the remaining trials (Jiang 2001a; Jiang 2001b; Lai 2006a; Yang 2002; Zhao 2004).

\section{Method of analysis}

Six trials reported per-protocol analyses (Fruehwald 2003; Jiang 2001a; Jiang 2001b; Lincoln 2003; Lipsey 1984; Towle 1989), four provided ITT analyses (Ponzio 2001; Reding 1986; Watkins 2007; Wiart 2000), and two used ITT in addition to per-protocol analyses (Andersen 1994; Murray 2002). The method of analysis was unclear in five trials (Lai 2006a; Ohtomo 1991; Rampello 2005; Yang 2002; Zhao 2004).

\section{Trial size and participants leaving the trial early}

The pharmacotherapy trials ranged in size from 17 (Reding 1986) to 285 (Ohtomo 1991) participants, with the drop-out rate ranging from 0\% (Jiang 2001a; Jiang 2001b; Ponzio 2001; Rampello 2005; Reding 1986) to $44 \%$ (Murray 2002). In the four psychotherapy trials, the number of participants ranged from 44 (Towle 1989) to 254 (Watkins 2007), with drop-out rates ranging from $2 \%$ (Towle 1989) to 6\% (Lincoln 2003).

\section{Effects of interventions}

Overall, 1655 participants were included in this review. In view of the large number and heterogeneous nature of the outcome measures and the reporting of results, we considered it inappropriate to pool outcome data for many endpoints.

\section{Pharmacotherapy}

Outcome data were available for 12 antidepressant interventions including 1121 participants (Andersen 1994; Fruehwald 2003; Jiang 2001a; Lai 2006a; Lipsey 1984; Murray 2002; Ohtomo 1991; Ponzio 2001; Rampello 2005; Reding 1986; Wiart 2000; Yang 2002). There was evidence of a benefit of pharmacotherapy in treating depression (remission) with a pooled OR of 0.47 (95\% CI 0.22 to 0.98 , Analysis 1.1 ) in the binary outcome measures the trial authors used, however there was substantial heterogeneity across individual studies. There was also evidence of a beneficial effect of pharmacotherapy in reducing (improving) scores on mood rating scales (response), however, because of the multiple scales used to assess mood in several individual trials (Andersen 1994; Fruehwald 2003; Lipsey 1984; Rampello 2005), we did not perform a meta-analysis (Analysis 1.2 and Analysis 1.3). Benefit of pharmacotherapy was also seen in the proportion of participants reporting a $50 \%$ or greater reduction in mood scores (OR 0.22, $95 \%$ CI 0.09 to 0.52 , Analysis 1.4 ), however, confidence intervals were wide for this endpoint and for average mood scores at the end of treatment which included significant effects both in favour of treatment and in favour of control. There was no evidence of benefit of pharmacotherapy in improving cognitive function. One trial showed a significant benefit on pharmacotherapy on anxiety (OR $0.48,95 \%$ CI 0.26 to 0.88 , Analysis 1.5 ) (Ohtomo 1991). There was no evidence of benefit of pharmacotherapy in improving activities of daily living, or reducing disability, as demonstrated by heterogeneous results with wide confidence intervals. Significant evidence of harm was demonstrated in adverse events (see Analysis 1.14), in particular central nervous system OR 1.96 (95\% CI 1.19 to 3.24), gastrointestinal OR 2.37 (95\% CI 1.38 to 4.06) and other less specific adverse events OR 1.51 (95\% CI 0.91 to 2.34). Outcome data were available for one combination preparation (Deanxit, a combination of flupentixol and melitracen) that included 45 people (Jiang 2001b). There was evidence of a benefit of pharmacotherapy in improving mood scores (secondary outcome, mean difference -8.09 (95\% CI -12.57 to -3.61, Analysis 2.1) and in neurological function (crude difference between mean scores at the end of treatment -2.19 (95\% CI -4.01 to -0.37, Analysis 2.4).

\section{Psychotherapy}

Depression data were available for three trials including 445 participants (Lincoln 2003; Watkins 2007; Zhao 2004) with some additional adverse event data available from one trial (Towle 1989). No treatment effect was demonstrated on any of the endpoints measured.

\section{DISCUSSION}

Seven new trials, four of pharmacotherapy (five interventions, Jiang 2001a; Lai 2006a; Ponzio 2001; Rampello 2005; Yang 2002) and two of psychotherapy (Watkins 2007; Zhao 2004), meeting our review criteria have become available since this review was first published in 2004. The addition of the new pharmacotherapy trials altered the results of the previous review and while there is now some evidence to support the use of pharmacotherapy to treat depression after stroke there is also stronger evidence of more adverse events for those receiving antidepressants. The results of this meta-analysis should also be considered in light of the recent meta-analysis showing a small benefit of SSRIs only in those with severe depression, with that benefit possibly being explained by fewer in this group responding to placebo (Kirsch 2008). The addition of the psychotherapy trials (Watkins 2007; Zhao 2004) did 
not change the previous review finding that there is no evidence of the effectiveness of psychotherapy for the treatment of depression after stroke.

Unfortunately, the results of the trials in this review did not allow for pooling of some key endpoints, so we have provided a predominantly narrative review of the evidence. However, this evidence of benefit must be considered alongside several basic methodological limitations of many of these trials, including the short duration of many interventions, variation in the types of trial participants recruited and the methods used to diagnose depression, lack of an a priori measurable endpoint, and the generally poor design, outcome assessment, analysis and interpretation of results. Of particular concern is the evidence of harm (more adverse events) given the small number of trials that systematically recorded and reported adverse events, making reliable the assessment of the benefits and risks of treatments impossible.

For pharmacotherapy trials, a key requirement is to achieve a therapeutic dose of the medication for an adequate period of time. The guidelines for the American College of Physicians suggest that antidepressants should be continued for at least four months beyond initial recovery, and that treatment should be changed if no response has been shown by six weeks (Snow 2000). In this review, the interventions in most pharmacotherapy trials were probably not given for an adequate length of time to show a maximal or sustained response. Therefore, we are unable to comment on the long-term effects of antidepressant therapy, or provide information on the most appropriate duration or dose of treatment, if one group of antidepressants is more efficacious, or provide stopping rules for antidepressant therapy in this group.

For psychotherapy trials, there is also good evidence that efficacy is linked to delivery of an adequate exposure to the intervention. This means that therapists should be trained and supervised in the therapy they are delivering, and use a standardised, pre-specified, framework for therapy. To achieve this in psychotherapy trials, the therapy is determined using a manual and the research therapists are trained and supervised in the use of the manual. Success in brief therapy is linked to adherence to the therapeutic model as well as to the therapists' characteristics. Future stroke psychotherapy trials should also adhere to these standard psychotherapy research guidelines if there is to be any probability of demonstrating consistency and response.

The trials in this review included participants with depression occurring several days to more than two years following stroke. However, depression occurring in the early phase of stroke is likely to be different from that occurring several months or years after the event. Survivors in the first weeks following stroke are coping with the consequences of experiencing a potentially life-threatening event, as well as recovering from the disabling effects of the stroke itself. In the medium to long-term, survivors of stroke are more likely to be adjusting to the prospects of permanent disability and changes in social and financial circumstances. It is difficult to summarise the evidence from such mixed populations, and even in doing so, whether it could be considered meaningful, especially given the high risk of relapse of depression in the first few months of recovery, which declines over time (Snow 2000).

In contrast to the wide range in the length of time between stroke onset and entry into the trial, many trials included patients with narrow demographic and clinical characteristics, in particular, they excluded patients with communication problems, cognitive loss, or previous psychiatric illness. This reinforces a common criticism of depression research, that the trial participants are not representative of those requiring treatment in the 'real world' (Zimmerman 2002). It would appear that this criticism is also applicable to trials of depression following stroke, where up to half of survivors may be excluded using such criteria (Turner-Stokes 2003). Given the high age of most patients with stroke, and the frequent presence of neurological impairments, aphasia and co-morbid medical conditions, the fact that up to half of all survivors of stroke are excluded limits the external validity (generalisability) of the results. The use of a large list of exclusions means that the results are applicable to only a small proportion of stroke survivors who have a narrow range of co-morbidities and other characteristics. Such exclusions may be justifiable for trials of psychotherapy, where participants are required to actively participate in therapy by talking, but seem inappropriate for the pharmacotherapy trials. Ideally, patients should be heterogeneous with regard to stroke diagnosis, which requires the use of standard diagnostic criteria and neuroimaging in a high proportion of cases. Given differences in the natural history and management of SAH it could be argued that this form of stroke should be examined separately.

The lack of a consistent method to diagnose depression, both for entry and outcome, in the included trials is a concern and a reflection of the general lack of a standard definition for a 'healthy state' among people with mood disorders (Keller 2003). Few trials stated whether the primary goal of therapy was remission (no longer meeting the baseline criteria for depression), response (a $50 \%$ reduction in mood scores from baseline), or simply a greater reduction in mood scores (or difference in scores) in one of the randomised groups. The complete remission of symptoms is arguably the most meaningful endpoint for the patient, whereas the significance of a small reduction in mood scores on a continuous scale is generally difficult to interpret for the patient and the treating physician. These problems with outcome assessment were further confounded by the frequent use of multiple scales both between and within trials. Because multiple scales were used in each trial, selective reporting of findings was also common. Any one scale was used across only eight trials at most, and significantly different cut-points were used to determine depression at entry and trial end. Given the practical difficulties and high cost of conducting psychiatric interviews in clinical trials it seems appropriate to adopt a pragmatic approach to determine depression 
on the basis of a validated mood questionnaire or semi-structured interview. Hopefully the compulsory registration of trial protocols on publicly available databases will reduce, if not eliminate, the opportunity for selective reporting of results. It has been suggested that more than one third of efficacy outcomes and half of harm outcomes are inadequately reported (Chan 2004).

Several other methodological deficiencies in trials further limit the conclusions that can be drawn from this review. Many trials were small, less than half reported adequate concealment of the randomisation sequence, and drop-out rates were high in several trials. One trial (Andersen 1994) excluded patients randomised before 28 days from their analyses, co-incidentally this group of patients experienced large responses in the placebo group. Additionally, blinding of investigators and outcome assessors was seldom stated. Reporting and analysis of results varied, with most (eight) trials presenting per-protocol analyses only or not specifying whether analyses were per protocol or ITT. For trials with high drop-out rates, ITT analysis of the data is very important. Researchers need to specify how missing data are handled (Hollis 1999). If ITT (giving missing data both the best possible and worst possible outcome) and per-protocol analysis indicate similar trends, the findings are likely to be interpreted as being clinically more robust. It continues to seem pertinent to recommend that researchers consult the ICH Harmonised Tripartite Guidelines for statistical principles for clinical trials (ICH 1999) and the revised CONSORT guidelines (Moher 2003) when designing, and reporting findings of, future trials.

\section{A U THORS' CONCLUSIONS}

\section{Implications for practice}

There is evidence from trials in stroke patients to tentatively support the use of prescription antidepressants to treat depression but this must be considered in light of the evidence of an associated increase in harm and of a lack of efficacy of SSRIs generally except in those with severe depression. Antidepressants may produce a remission or a response in terms of lower scores on mood rating scales, but also increase adverse events. It is recommended that these agents are used with caution in those with a persistent depressive disorder after stroke, as little is known about the risks, especially of seizures, falls and delirium, especially in older people and those on concomitant medication. We found no evidence for the benefit of psychotherapy.

\section{Implications for research}

We recommend the need for further research in this area. Future trials investigating the effect of pharmacotherapy and psychotherapy in the treatment of depression in people after stroke should address the following:

- review and refine the methods for trials of psychological endpoints in people with physical illness;

- recruit an adequate number of participants so that variables such as time passed between stroke and recruitment, and inclusion of patients with dysphasia, and SAH can be controlled, and modest but clinically important effects can be detected;

- recruit a representative 'real world' sample of patients to enable results to be generalised to the majority of stroke survivors;

- provide treatment for a sufficient duration and follow up, so that rates of relapse or maintenance of remission can be assessed;

- psychotherapy interventions need to be carefully specified and monitored;

- include careful, prospective assessment and complete reporting of adverse events;

- define a priori an unambiguous, measurable, primary endpoint;

- limit the number of secondary outcomes to three or four and report results for all outcomes.

\section{ACKNOWLEDGEMENTS}

The review was supported by a grant from the Stroke Society of Australasia in 2003, with additional financial assistance provided by the Academic Unit of Psychiatry, The University of Leeds, and the Department of Clinical Neurosciences, The University of Edinburgh. We thank the Cochrane Stroke Group, particularly Brenda Thomas, for searching the Cochrane Stroke Registers and assistance with developing the search strategies. We also thank Hazel Fraser for assistance throughout the review process, and Christina Halteh $(\mathrm{CH})$, a pharmacology honours student, for assisting with data extraction for the update. 


\section{REFERENCES}

\section{References to studies included in this review}

\section{Andersen 1994 \{published data only\}}

Andersen G, Vestergaard K, Lauritzen L. Effective treatment of post-stroke depression with the selective serotonin reuptake inhibitor, citalopram. Journal of Neurology 1994; 241 Suppl 1:S42.

* Andersen G, Vestergaard K, Lauritzen L. Effective treatment of poststroke depression with the selective serotonin reuptake inhibitor citalopram. Stroke 1994;25(6): 1099-104.

Andersen G, Vestergaard K, Lauritzen L. Post-stroke depression treated with citalopram. Acta Neurologica Scandinavica 1994;89 Suppl 155:20.

Andersen G, Vestergaard K, Lauritzen L. Post-stroke depression treated with citalopram a selective serotonin reuptake inhibitor. Proceedings of the 7th Scandinavian meeting on Cerebrovascular Disease. Jyvaskyla, Finland, 14-17 August 1993:54.

Andersen G, Vestergaard K, Lauritzen L. Post-stroke depression treated with citalopram - a selective serotonin reuptake inhibitor. Canadian Journal of Neurological Sciences 1993;20(Suppl 4):S115.

Andersen G, Vestergaard K, Lauritzen LU. Effective treatment of depression following apoplexy with citalopram. Ugeskrift for Laeger 1995;157(14):2000-3.

Flicker C, Andersen G, Bayer L. A placebo-controlled study of citalopram treatment for post-stroke depression. Proceedings of the 11th Annual Meeting of the American Association for Geriatric Psychiatry. San Diego, California, USA, 1998.

\section{Fruehwald 2003 \{published data only\}}

Fruehwald S, Gatterbauer E, Rehak P, Baumhackl U. Early fluoxetine treatment of post-stroke depression: a three months double-blind placebo-controlled study with an open-label long-term follow up. Journal of Neurology 2003; 250(3):347-51.

\section{Jiang 2001a \{published data only\}}

Jiang B, Lu W, Song X-W, Tan L-M, Hu Z-P. The effect of poststroke depression interventions on the recovery of neurological function. Modern Rehabilitation 2001;5(3): 29-30.

Jiang 2001b \{published data only\} Jiang B, Lu W, Song X-W, Tan L-M, Hu Z-P. The effect of poststroke depression interventions on the recovery of neurological function. Modern Rehabilitation 2001;5(3): 29-30.

Lai 2006a \{published data only\}

Lai J, Zeng G. The effect of using paroxetine to treat post stroke depression. Journal of Guangdong Medical College 2006;24(6):585-6.

\section{Lincoln 2003 \{published data only\}}

Flannaghan T. Cognitive behavioural psychotherapy for the treatment of depression after stroke. Unpublished. University of Nottingham, Nottingham, 2000.

${ }^{*}$ Lincoln NB, Flannaghan T. Cognitive behavioral psychotherapy for depression following stroke: a randomized controlled trial. Stroke 2003;34:111-5. Thomas SA, Lincoln NB. Factors relating to depression after stroke. British Journal of Clinical Psychology 2006;45: $49-61$.

\section{Lipsey 1984 \{published data only\}}

Kimura M, Tateno A, Robinson RG. Treatment of poststroke generalized anxiety disorder comorbid with poststroke depression: merged analysis of nortriptyline trials. American Journal of Geriatric Psychiatry 2003;11(3): 320-7.

Lipsey JR, Robinson RG. Nortriptyline for post-stroke depression. Lancet 1984;1(8380):803.

* Lipsey JR, Robinson RG, Pearlson GD, Rao K, Price TR. Nortriptyline treatment of post-stroke depression: a doubleblind study. Lancet 1984;1(8372):297-300.

\section{Murray 2002 \{published data only\}}

* Murray V, Von Arbin M, Asberg M, Bartfai A, Berggren A, Landtblom A, et al.Double-blind placebo comparison of sertraline and placebo in stroke patients with depression. Unpublished 2003.

Murray V, Von Arbin M, Bartfai A, Berggren A, Landtblom A, Lundmark J, et al.Double-blind comparison of sertraline and placebo in stroke patients with minor depression and less severe major depression. Journal of Clinical Psychiatry 2005;66(6):708-16.

Murray V, Von Arbin M, Varelius R, Olsson JE, Terent A, Samuelsson M, et al.Sertraline in poststroke depression: a controlled study. Stroke 2002;33(1):P292.

\section{Ohtomo 1991 \{published data only\}}

Kumar V. Post-stroke depression and treatment strategies including aniracetam. International Journal of Geriatric Psychopharmacology 1999;2:40-6.

* Ohtomo E, Hirai S, Terashi A, Hasegawa K, Tazaki Y, Araki G, et al.Clinical evaluation of aniracetam on psychiatric symptoms related to cerebrovascular disease. Journal of Clinical Experimental Medicine 1991;156:143-87.

Ponzio 2001 \{published data only\}

* An 8-week, double-blind, placebo controlled, parallel group study to assess the efficacy and tolerability of paroxetine in patients suffering from depression following stroke. http://www.ctr.gsk.co.uk/Summary/Paroxetine/ III_PAR_625.pdf issue par 625.

Ponzio F, Marini G, Riva E. The efficacy of paroxetine in some kinds of "critical" patients. European Neuropsychopharmacology 2001;11 Suppl 2:S49-S50 Abstract P.1.29. 
Rampello 2005 \{published data only\}

Rampello L, Alvano A, Chiechio S, Raffaele R, Vecchio I, Malaguarnera M. An evaluation of efficacy and safety of reboxetine in elderly patients affected by "retarded" poststroke depression: A random, placebo-controlled study. Archives of Gerontology and Geriatrics 2005;40:275-85.

\section{Reding 1986 \{published data only\}}

Reding MJ, Orto LA, Winter SW, Fortuna IM, Di Ponte P, McDowell FH. Antidepressant therapy after stroke: a double-blind trial. Archives of Neurology 1986;43(8):763-5.

\section{Towle 1989 \{published data only\}}

* Towle D, Lincoln NB, Mayfield LM. Evaluation of social work on depression after stroke. Clinical Rehabilitation 1989;3(2):89-96

Towle D, Lincoln NB, Mayfield LM. Service provision and functional independence in depressed stroke patients and the effect of social work intervention on these. Journal of Neurology, Neurosurgery and Psychiatry 1989;52(4):519-22. Towle D, Mayfield L, Lincoln M. Depression after stroke. Clinical Rehabilitation 1988;2:256.

Watkins 2007 \{published and unpublished data\} Deans CF, Jack CIA. Evaluation of motivational interviewing early after acute stroke: a randomized controlled trial. Clinical Rehabilitation 2006;20:731-6. Sutton C, Dickinson H, Leathley M, Hills K, Auton M, Lightbody E, et al.Motivational interviewing: altering outcome after stroke. 12th European Stroke Conference. Valencia, Spain, 2003 May 21-24:103.

* Watkins CL, Auton MF, Deans CF, Dickinson HA, Jack CIA, Lightbody CE, et al.Motivational interviewing early after acute stroke: a randomized, controlled trial. Stroke 2007;38:1004-9.

\section{Wiart 2000 \{published data only\}}

Wiart L, Gassies TD, France B, Petit H, Debelleix D. A double-blind, placebo controlled trial to study the efficacy and tolerance of fluoxetine in the treatment of early post stroke depression. Proceedings of the 152nd Annual Meeting of the American Psychiatric Association. USA, Washington: American Psychiatric Association, 15-20 May 1999.

* Wiart L, Petit H, Joseph PA, Mazaux JM, Barat M. Fluoxetine in early poststroke depression: a double-blind placebo-controlled study. Stroke 2000;31(8):1829-32.

Yang 2002 \{published data only\}

Yang J, Zhao Y, Bai S. Controlled study on antidepressant treatment of patients with post-stroke depression. Chinese Journal of Psychology 2002;16(12):871-2.

Zhao 2004 \{published data only\} Zhao H-W, Zhou C-X, Su X-L, Xiao X-C, Guo Y. Effect of mental intervention on post-stroke depression and rehabilitation of neurological function. Chinese Journal of Clinical Rehabilitation 2004;8(13):2408-9.

\section{References to studies excluded from this review}

\section{Agnoli 1985 \{published data only\}}

Agnoli A, Fioravanti M, Lechner H. Efficacy of CDPCholine in chronic cerebral vascular diseases (CCVD). In: Appia V, Kennedy EP, Nilsson BI, Galletti P editor(s). Novel Biochemical, Pharmacological and Clinical Aspects of Cytidinediphosphocholine. New York: Elsevier, 1985: 305-15.

\section{Aizawa 1986 \{published data only\}}

Aizawa T, Hasegawa T, Ohtomo E, Araki G, Hirai S, Terashi A, et al.Clinical evaluation of KC-404 in the treatment of cerebrovascular disorders: multi-center double-blind study in comparison with nicardipine hydrochloride. Rinsho Hyoka (Clinical Evaluation) 1986;14(2):343-72.

Balunov 1990 \{published data only\} Balunov OA, Sadov OG, Alemasova AY. Therapy of depressions in post-stroke patients. Alaska Medicine 1990; 32(1):20-9.

Bao 2001 \{published data only\} Bao X, Wang G, Liu X, Zhang B, Zhao Y, Gao C, et al.Depression and corresponding psychological intervention after stroke. Chinese Mental Health Journal 2001;15(4): 260-2.

Battaglia 1999 \{published data only\} Battaglia A, Bejor M, Petri M, Beumgarde D, Bartalini B. Analysis of cognitive functions after venlafaxine treatment in post-stroke depression. Nuova Rivista di Neurologia 1999; 9(1):15-27.

Battaglia 2001 \{published data only\} Battaglia A, Bejor M. Influence of poststroke depression on functional outcome. Europa Medicophysica 2001;37(1): 25-37.

Bautz-Holter 2002 \{published data only\} Bautz-Holter E, Sveen U, Rygh J, Rodgers H, Bruun Wyller T. Early supported discharge of patients with acute stroke: a randomized controlled trial. Disability and Rehabilitation 2002;24(7):348-55.

\section{Berrol 1997 \{published data only\}} Berrol CF, Ooi WL, Katz SS. Dance/movement therapy with older adults who have sustained neurological insult: a demonstration project. American Journal of Dance Therapy 1997;19(2):135-60.

Casella 1960 \{published data only\} Casella C, Sokolow J. A study to determine the energizing effects of iproniazid (marsilid) on a group of hemiplegics. Archives of Physical Medicine and Rehabilitation 1960;41: 381-5.

Chen 2001 \{published data only\} Chen W, Liu F, Yang A. Effects of fluoxetine and Chinese traditional medicine on nervous recovery after stroke. Journal of Chengdu University of TCM 2001;24(4):20-41.

Chen 2002 \{published data only\}

Chen X-J, Lin Z-X, Li J-L, Zhou X-B. An observation of the effect of anti-depressants on poststroke depression and nervous function recovery. Chinese Journal of Clinical Rehabilitation 2002;6(9):1289. 
Chen 2005 \{published data only\}

Chen K-N, Chen S-L, Luo F, Tan Y-Y. Changes of neurotransmitter in patients with post-stroke depression observed with encephalofluctuography technology. Zhongguo Linchuang Kangfu 2005;9:118-9.

\section{Chen 2005a \{published data only\}}

Chen Y-P, Mei Y-W, Sun S-G, Bao M, Yu S-C. Evaluation of frequency repetitive transcranial magnetic stimulation for post-stroke depression and neurologic impairment. Zhongguo Linchuang Kangfu 2005;9:18-9.

\section{Cheng 2003 \{published data only\}} Cheng F, Shao GF, Bao SR. Study of effect of fluoxetine on rehabilitation of neurologic function among patients with post-stroke depression. Chinese Journal of Clinical Rehabilitation 2003;7:108-9.

\section{Cheng 2003a \{published data only\}}

Cheng F, Shao G, Bao S. Study of effect on neurologic function rehabilitation in patients with post-stroke depression. Chinese Journal of Clinical Rehabilitation 2003; 7(1):108-9.

\section{Choi-Kwon 2006 \{published data only\}}

Choi-Kwon S, Choi J, Kwon SU, Kang D, Kim JS. Fluoxetine is not effective in the treatment of poststroke fatigue: a double-blind, placebo controlled study. Cerebrovascular Diseases 2007;23:103-8.

* Choi-Kwon S, Han SW, Kwon SU, Kang D, Kim CS, Kim JS. Fluoxetine treatment in poststroke depression, emotional incontinence, and anger proness: a double-blind, placebo-controlled study. Stroke 2006;37:156-61. Kim JS. Post-stroke emotional disturbances. Symposium 3: Prevention of Recurrent Vascular Events and Other Complications of Stroke. 2005.

\section{Christie 1984 \{published data only\}} Christie D, Weigall D. Social work effectiveness in two-year stroke survivors: a randomised controlled trial. Community Health Studies 1984;8(1):26-32.

\section{Corr 1995 \{published data only\}}

Corr S, Bayer A. Occupational therapy for stroke patients after hospital discharge: a randomized controlled trial. Clinical Rehabilitation 1995;9(4):291-6.

Corr 2004 \{published data only\} Corr S, Phillips CJ, Walker M. Evaluation of a pilot service designed to provide support following stroke: a randomized cross-over design study. Clinical Rehabilitation 2004;18: 69-75.

\section{Cui 2001 \{published data only\}}

Cui DD. Depression associated with acute cerebral stroke. Hong Kong Medical Journal 2001;7(4):32.

\section{Cullum 2007 \{published data only\}}

Cullum S, Tucker S, Todd C, Brayne C. Effectiveness of liaison psychiatric nursing in older medical inpatients with depression: a randomised controlled trial. Age and Ageing 2007;36:436-42.

Davis 1997 \{published and unpublished data\}

* Davis MC. Life review therapy as an intervention to manage depression and enhance life satisfaction in individuals with right hemisphere cerebral vascular accidents. Issues in Mental Health Nursing 2004;25:503-15. Davis MC. Life review therapy as an intervention to manage depression and enhance life satisfaction in individuals with right hemisphere cerebral vascular accidents. PhD Thesis, Mississippi State University 1997.

Dennis 1997 \{published data only\}

Dennis M, O’Rourke S, Slattery J, Staniforth T, Warlow C, McLean S. Evaluation of a stroke family care worker: results of a randomised controlled trial. BMJ 1997;314(7087): 1071-7.

Dennis 2000 \{published data only\} Dennis M, O'Rourke S, Lewis S, Sharpe M, Warlow C. Emotional outcomes after stroke: factors associated with poor outcome. Journal of Neurology, Neurosurgery and Psychiatry 2000;68(1):47-52.

Desrosiers 2007 \{published data only\}

Desrosiers J, Noreau L, Rochette A, Carbonneau H, Fontaine L, Viscogliosi C, et al.A home leisure education program may reduce depression after a stroke. Stroke 2007; 38(2):473-4.

\section{Dong 2007 \{published data only\}}

Dong JP, Sun WY, Wang S, Wu Z, Liu F. Clinical observation on head point-through-point electroacupuncture for treatment of poststroke depression. Zhongguo Zhen Jiu 2007;27:241-4.

\section{Downes 1995 \{published data only\}}

Downes B, Rooney V, Oyebode JR, Roper-Hall A, Mayer P, Main A. The effect of giving information and counselling on depression and anxiety in stroke survivors and carers (The Birmingham Stroke Counselling Project). Unpublished 1995.

\section{Drummond 1995 \{published data only\}} Drummond AER, Walker MF. A randomized controlled trial of leisure rehabilitation after stroke. Clinical Rehabilitation 1995;9(4):283-90.

Du 2005 \{published data only\}

Du D-Q, Wu Y-B. Living ability and cognitive function ameliorated by low frequency repetitive transcranial magnetic stimulation in patients with post-stroke depression: Comparison with drug plus psychological treatment. Zhongguo Linchuang Kangfu 2005;9:22-3.

\section{Evans 1997 \{published data only\}}

Evans M, Hammond M, Wilson K, Lye M, Copeland J. Treatment of depression in the elderly: effect of physical illness on response. International Journal of Geriatric Psychiatry 1997;12:1189-94.

Feng 2004 \{published data only\}

Feng B, Wang Q, Li Z. Influence of Jieyu Huoxue decoction on rehabilitation of patients with depression after cerebral infarction. Journal of Chinese Integrative Medicine 2004;2 (3):182-4.

Feng 2005 \{published data only\} Feng SZ, Zhang MY, Dai ZH. Impacts of rehabilitative therapy on post-stroke depression and the ability of daily 
life. Chinese Journal of Clinical Rehabilitation 2005;9(13): $154-5$.

\section{Fengqi 2003 \{published data only\}}

Fengqi W, Xiaorui D, Yunxia P, Min L. Effect of Yukangning in the treatment of post stroke depression and nerve function recovery. Chinese Journal of Clinical Rehabilitation 2003;7(99):1225.

\section{FX Project 1976 \{published data only\}} FX Project for Phase III Study. Double blind study of FX505 (Ifenprodll) on cerebrovascular diseases: phase III study. Rinsho Hyoka (Clinical Evaluation) 1976;4(3):419-58.

Gekht 2002 \{published data only\}

Gekht AB, Bogolepova AN, Sorokina IB. Post-stroke depression: the experience of using cipramil. Zhurnal Nevropatologii I Psikhiatrii Imeni S S Korsakova 2002;102 (5):36-9.

Gekht 2003 \{published data only\}

Gekht AB, Sorokina IB, Bogolepova AN, Gdukova AA. Experience with ixel (milnaciprane hydrochloride) treatment of poststroke depression. Terapevticheskii Arkhiv 2003;75(10):34-8.

\section{Goh 2001 \{published data only\}}

Goh M. The role of music therapy in the rehabilitation of people who have had strokes, specifically focusing on depression. National Research Register 2001.

Gonzalez-T 1995 \{published data only\}

Gonzalez-Torrecillas JL, Mendlewicz J, Lobo A.

Effects of early treatment of poststroke depression on neuropsychological rehabilitation. International Psychogeriatrics 1995;7(4):547-60.

Graffagnino 2003 \{published data only\}

Graffagnino C. Poststroke depression and functional recovery (SADBRAIN). Duke University Medical Centre (Unpublished) 2003.

\section{Green 2002 \{published data only\}}

Green J, Forster A, Bogle S, Young J. Physiotherapy for patients with mobility problems more than 1 year after stroke: a randomised controlled trial. Lancet 2002;359 (9302):199-203.

\section{Guan 2003 \{published data only\}}

Guan L. The comparison of effects of Fluoxetine and Levodopa treating post-stroke depression. Chinese Journal of Clinical Rehabilitation 2003;7(7):1168.

Guan 2004 \{published data only\} Guan WB, Gao DJ, Li AM, Ouyang S, Dai ZC. Recent effects of early psychological intervention for patients with post-stroke depression. Chinese Journal of Clinical Rehabilitation 2004;8(31):6832-3.

He 2001 \{published data only\}

He X. Approaches to the treatment methods of post stroke depression. Modern Rehabilitation 2001;5(8):34-5.

He 2003 \{published data only\}

He C. The effect of psychological intervention combined with amitriptyline on patients with depression after stroke. Chinese Journal of Clinical Rehabilitation 2003;7(5):850.

\section{He 2004 \{published data only\}}

He P, Kong Y, Xu L. Randomised controlled observation of the effect of early application of fluoxetine in preventing depression after stroke. Chinese Journal of Clinical Rehabilitation 2004;8(28):6016-7.

He 2005 \{published data only\}

He Y, Wang X, Xiao CL, Xiang SW, Liu WQ. Prospective study of effects of paroxetine with mental intervention of depression and anxiety after stroke. Nervous Diseases and Mental Health 2005; Vol. 5:6-9.

\section{Hindle $2007\{$ published data only\}}

Hindle J. A randomised double-blind placebo controlled study of the treatment of post-stroke depression. National Research Register. [: M0055144040]

Hogg 1985 \{published data only\}

Hogg PK. The effects of acupuncture on the psychological and physiological rehabilitation of the stroke patients (stress, relaxation, pain). Berkeley/Alameda: California School of Professional Psychology 1985.

\section{Hong 2004 \{published data only\}}

Hong J, Li J. Comparison of the curative effects of yuxingchangzhi tang and fluoxetine in the treatment of poststroke depression. Chinese Journal of Clinical Rehabilitation 2004;8(13):2504-5.

\section{House 2005 \{unpublished data only\}}

House AO, Bamford J, Sheldon T, Young J, Forster A, Knapp P, et al.Depression in the first weeks after stroke. www.leeds.ac.uk/medicine/psychiatry/research/ strokedep.htm 2005.

* Ruddell M, Spencer A, Hill K, House A. Fluoxetine vs placebo for depressive symptoms after stroke: failed randomised controlled trial. International Journal of Geriatric Psychiatry 2007;22:963-5.

Hu 2002 \{published data only\}

$\mathrm{Hu}$ Y, Suo A, Xiang L, Zhao J. The comparative study of the effectiveness of Fluoxetine on the stroke patients with depressive symptoms. Shanghai Mental Health Journal 2002;14(3):149-50.

Hu 2005 \{published data only\} Hu TT, Zhu SQ. Effect of fluoxetine on the depressive status and quality of life in patients with stroke. Chinese Journal of Clinical Rehabilitation 2005;9(12):6-7.

\section{Huang 2001 \{published data only\}}

Huang C, Wang J. The Influence of the treatment of poststroke depression on the rehabilitation of neurological function. Academic Journal of Guangzhou Medical College 2001;29(2):60-2.

\section{Huang 2004 \{published data only\}}

Huang D-H, Wang C-Y, Huang J-H, Ye Y, Chen X-H. Point-injection therapy combining baihui acupuncture with parenteral solution of breviscapine for postcerebral infarction depression. Chinese Journal of Clinical Rehabilitation 2004;8(28):6132-3. 
Hui 1995 \{published data only\}

Hui E, Lum CM, Woo J, Or KH, Kay RLC. Outcomes of elderly stroke patients: day hospital versus conventional medical management. Stroke 1995;26(9):1616-9.

Isenberg 2000 \{published data only\} Isenberg N. A double-blind, placebo controlled, doseranging study of nefiracetam in patients with post stroke depression. http://www.wfubmc.edu/neurology/research 2004.

* Isenberg N. A double-blind, placebo controlled, doseranging study of Nefiracetam in patients with post-stroke depression. Daiichi Pharmaceutical Co.

\section{Ji 2000 \{published data only\}}

Ji QM, Xie LP. Efficacy of fluoxetine in the treatment of 20 patients with depression after stroke. Herald of Medicine 2000;19(4):329.

Jia 2005 \{published data only\} Jia W, Zhang XL, Zhang DB, Liu MY. Effect of early intervention on recovery of motor function and recurrent stroke in patients with post-stroke depression. Chinese Journal of Clinical Rehabilitation 2005;9(12):4-5.

Johnson 2000 \{published data only\}

* Johnson J, Pearson V. The effects of a structured education course on stroke survivors living in the community. Rehabilitation Nursing 2000;25(2):59-65.

Pearson V, Johnson J. Educational intervention reduces occurrence of depression in community-dwelling stroke survivors. Stroke 2005;36(2):423.

Jongbloed 1991 \{published data only\}

Jongbloed L, Morgan D. An investigation of involvement in leisure activities after a stroke. American Journal of Occupational Therapy 1991;45(5):420-7.

Jorge 2004 \{published data only\} Jorge RE, Robinson RG, Tateno A, Narushima K, Acion L, Moser D, et al.Repetitive transcranial magnetic stimulation as treatment of poststroke depression: a preliminary study. Biological Psychiatry 2004;55:398-405.

Joubert 2006 \{published data only\}

Joubert J, Reid C, Joubert L, Barton D, Ruth D, Jackson D, et al.Risk factor management and depression post-stroke: the value of an integrated model of care. Journal of Clinical Neuroscience 2006;13:84-90.

Juby 1996 \{published data only\}

Juby LC, Lincoln NB, Berman P, Drummond A, Miller N, Colquhoun $\mathrm{M}$, et al.The effect of a stroke rehabilitation unit on functional and psychological outcome: a randomised controlled trial. Cerebrovascular Diseases 1996;6(2):106-10.

Kendall 2007 \{published data only\}

Kendall E, Catalano T, Kuipers P, Posner N, Buys N, Charker J. Recovery following stroke: the role of selfmanagement education. Social Science \& Medicine 2007;64: 735-46.

Kwon 2003 \{published data only\}

Kwon S-S. The effects of the taping therapy on range of motion, pain and depression in stroke patients. Journal of the Korean Academy of Nursing 2003;33(5):651-8.
Lai 2006b \{published data only\}

Lai SM, Studenski SM, Richards L, Perera S, Reker D, Rigler $S$, et al.Therapeutic exercise and depressive symptoms after stroke. Journal of American Geriatric Society 2006;54: 240-7.

\section{Laska 2005 \{published data only\}}

Laska AC, van Arbin M, Kahan T, Hellblom A, Murray $\mathrm{V}$. Long-term antidepressant treatment with moclobemide for aphasia in acute stroke patients: a randomised, doubleblind, placebo-controlled study. Cerebrovascular Diseases 2005;19(2):125-32.

\section{Lauritzen 1994 \{published data only\}}

Lauritzen L, Bendsen BB, Vilmar T, Bendsen EB, Lunde M, Bech P. Post-stroke depression: combined treatment with imipramine or desipramine and mianserin: a controlled clinical study. Psychopharmacology 1994;114(1):119-22.

Lee 2005 \{published data only\} Lee NG, Choi IS, Kim JH, Lee SY, Han JY. The effect of repetitive transcranial magnetic stimulation on the poststroke depression. Proceedings of the Proceedings of 3rd World Congress of the International Society of Physical and Rehabilitation Medicine - ISPRM. Brazil, Sao Paulo, 10-14 April 2005:105-9.

\section{Lehmann 2001 \{published data only\}}

Lehmann V, Heldebrandt H, Olthaus O, Sachsenheimer W. Drug influence on visuospatial attention deficit in patients with right hemisphere media infarction. Aktuelle Neurologie 2001;28(4):176-81.

Leijon 1989 \{published data only\}

Leijon G, Boivie J. Central post-stroke pain: a controlled trial of amitriptyline and carbamazepine. Pain 1989;36(1): 27-36.

Li 1994 \{published data only\}

Li C-D, Huang Y, Li Y-K, Hu K-M, Jiang Z-Y.

Treating post-stroke depression with "mind-refreshing antidepressive" acupuncture therapy: a clinical study of 21 cases. International Journal of Clinical Acupuncture 1994;5 (4):389-93.

Li 1999 \{published data only\}

Li W, Chen Z, Shan B, Li D. Comparison of therapeutic effects of domestic and imported fluoxetine in treatment of post-stroke depression. Chinese New Drugs Journal 1999;8 (3):193-5.

Li 2000 \{published data only\} Li W-Q, Chen Z-H, Shan B-S, Li D-P. Flupentixol/ melitracen in treatment of poststroke depression. Zhongguo Xinyao Yu Linchuang Zazhi 2000;19(3):193-5.

Li 2002 \{published data only\}

Li F, Gu D-x, Deng S-h, Xu J-w. Effect of paroxetine on prognosis of patients with post cerebral infarction depression. Zhongguo Xinyao Yu Linchuang Zazhi 2002;21 (1):11-3.

Li 2004 \{published data only\} Li J, He Q-Y, Han M-F. Recent effect of fluoxetine in improving neurologic impairment and preventing post- 
stroke depression in the early stage. Chinese Journal of Clinical Rehabilitation 2004;8(7):1208-9.

\section{Li 2004a \{published data only\}}

Li W-D, Huang B-B. Effects of the treatment for post-stroke depression on the recovery of motor function and ability of daily living. Chinese Journal of Clinical Rehabilitation 2004; 8(13):2410-1.

Li 2004b \{published data only\}

Li G, Li J, Cheng L, Ma E, Pang Y, Zhu C. Early comprehensive intervention on post-stroke depression. Chinese Mental Health Journal 2004;18(1):15-7.

Li 2004c \{published data only\} Li C-M, Jiang X-D, Liao G, Lei C-M, Lan S, Ni F-W. Effect of antidepressant drugs in early period on the recovery of post-stroke depression. Chinese Journal of Clinical Rehabilitation 2004;8(19):3713-5.

\section{Li 2004d \{published data only\}}

Li N-G, Liu Q-G, You G-X. Effects of psychological rehabilitation on the prognosis of stroke patients with depression at early recovery stage. Chinese Journal of Clinical Rehabilitation 2004;8(22):4412-3.

Li 2005 \{published data only\}

Li W-X, Wang J-R, Sun S-G, Xia Z-L, Zhu L-Z. Association of post-stroke depression with stroke site and severity of neurologic impairment. Zhongguo Linchuang Kangfu 2005; 9:18-9.

\section{Liang 2003 \{published data only\}}

Liang Z, Tang S, Liu J. Clinical efficacy of Fluoxine in treatment of patients with depression after acute stroke. Chinese Journal of Clinical Rehabilitation 2003;7(13): 1924-5.

\section{Liang 2005 \{published data only\}}

Liang S-Q, Peng X-S, Yang J-H. Influence of antidepressant treatment on the cognitive function and cerebral blood flow in patients with post-stroke depression. Zhongguo Linchuang Kangfu 2005;9:20-1.

Liborio 2002 \{published data only\}

Liborio R, Santina C, Giovanni N, Alessandro A, Rocco R, Mariano M. Prediction of the response to citalopram and reboxetine in post-stroke depressed patients. Unpublished 2002 .

Lin 2005 \{published data only\} Lin H, Gu Y-P, Wang K, Zhou W-Y. Influence of poststroke depression on the effects of rehabilitation. Zhongguo Linchuang Kangfu 2005;9:15-7.

\section{Lincoln 1985 \{published data only\}}

Lincoln N, Jones AC, Mulley GP. Psychological effects of speech therapy. Journal of Psychosomatic Research 1985;29 (5):467-74.

Liu 2003 \{published data only\} Liu C, Zhang Y, Wang Z. Treatment to depression after silent cerebral infarction. Chinese Journal of Clinical Psychology 2003;11(1):67-8.

\section{Liu 2003a \{published data only\}}

Liu J, Li J, Dong W. A clinical study of fastigial nucleus electrical stimulation on poststroke depression. Chinese Journal of Clinical Rehabilitation 2003;7(13):1926-7.

\section{Liu 2006 \{published data only\}}

Liu F, Chen W, Chen W, Sun H. Influence of Yu-LeShu capsules on the depressive behaviour and functional recovery of PSD patients. Journal of Chengdu University of TCM 2006;29(3):12-5.

Liu 2006a \{published data only\}

Liu SK, Zhao XM, Xi ZM. Incidence rate and acupuncturemoxibustion treatment of post-stroke depression. Zhongguo Zhen Jiu 2006;26:472-4.

Liu 2006b \{published data only\} Liu G, Liu R, Wang Y, He G. Clinical control study of citalopram and amitriptyline in the treatment of post-stroke depression. Journal of Clinial Psychological Medicine 2006; 16:153-4.

Lu 2005 \{published data only\}

Lu X, Lu B, Gu X, Chen X, Zhou H, Jin Y. Cognitive therapy in combination with electromyographic feedback in treatment of diabetes patients with depression after cerebral infarction. Chinese Journal of Clinical Psychology 2005;13 (2):215-6.

Mant 1998 \{published data only\}

Mant J, Carter J, Wade DT, Winner S. The impact of an information pack on patients with stroke and their carers: a randomized controlled trial. Clinical Rehabilitation 1998 ; 12(6):465-76.

Mant 2000 \{published data only\} Mant J, Carter J, Wade DT, Winner S. Family support for stroke: a randomised controlled trial. Lancet 2000;356 (9232):808-13.

Martucci 1986 \{published data only\} Martucci N, Manna V, Mailland F. Electroencephalographicpharmacological and neuropsychological study of dihydroergocristine mesylate in patients with chronic cerebrovascular disease. Advances in Therapy 1986;3(4): 210-23.

Mauri 1988 \{published data only\} Marui L, Arboix A, Marti-Vilalta JL. Efficacy of antidepressive treatment in affective disorders associated to ischemic vascular disease. Neurologia 1988;3(Suppl 3):10.

Meara 1998 \{published data only\}

Meara JR. A randomised double blind placebo controlled study of the treatment of post stroke depression. National Research Register.

* Meara RJ, Thalanany M, Balonwu V, Hobson P. The treatment of depression after stroke with the selective serotonin reuptake inhibitor sertraline. Cerebrovascular Diseases 1998;8 Suppl 4:90.

Meng 1996 \{published data only\}

Meng Q, Sun Y, Chen X, Jin S, Lu S, Sun C. Comparative therapeutic effects of Mi-An-She-Lin and amitriptyline on post stroke depression. Chinese Journal of Nervous \& Mental Diseases 1996;22(1):37-8. 
Miao 2004 \{published data only\}

Miao S-Y, Shi Y-J. Related factors of post-stroke depression and therapeutical effect of citalopram. Chinese Journal of Clinical Rehabilitation 2004;8(19):3718-9.

Min 2002 \{published data only\}

Min L, Li X, Zhang H, Ding Z, Yuan J, Ma W, et al.Curative effect comparison of mental rehabilitation and drugs therapy in patients with post-stroke depression. Chinese Journal of Clinical Rehabilitation 2002;6(7):945-6.

Min 2002a \{published data only\} Min L-Q, Li X, Zhang H-M. A comparison of drug therapy and psychological rehabilitation therapy treating poststroke depression. Chinese Journal of Clinical Rehabilitation 2002; 6(7):945-6.

\section{Miyai 1998 \{published data only\}}

Miyai I, Reding MJ. Effects of antidepressants on functional recovery following stroke: a double-blind study. Journal of Neurologic Rehabilitation 1998;12(1):5-13.

Niedermaier 2004 \{published data only\}

Niedermaier N, Bohrer E, Schulte K, Schlattmann P, Heuser I. Prevention and treatment of poststroke depression with mirtazapine in patients with acute stroke. Evidence Based Mental Health 2005;8(3):74.

* Niedermaier N, Bohrer E, Schulte K, Schlattmann P, Heuser I. Prevention and treatment of poststroke depression with mirtazapine in patients with acute stroke. Journal of Clinical Psychiatry 2004;65(12):1619-23.

Nir 2004 \{published data only\}

Nir Z, Zolotogorsky Z, Sugarman H. Structured nursing intervention versus routine rehabilitation after stroke. American Journal of Physical Medicine and Rehabilitation 2004;83:522-9.

Nour 2002 \{published data only\}

Nour K, Desrosiers J, Gauthier P, Carbonneau H. Impact of a home leisure educational program for older adults who have had a stroke (home leisure educational program). Therapeutic Recreation Journal 2002;36(1):48-64.

Ohtomo 1985 \{published data only\}

Ohtomo E, Kutsuzawa T, Araki G, Hirai S, Terashi A, Kuzuya F, et al.Clinical usefulness of tiapride on psychiatric symptoms caused by cerebrovascular disorders. Clinical Evaluation 1985;13:295-332.

Ostwald 2006 \{published data only\}

Ostwald S. Intervention for stroke survivors and spousal caregivers. www.clinicaltrials.gov 2001.

* Ostwald SK, Wasserman J, Davis S. Medications, comorbidities, and medical complications in stroke survivors: the CAReS study. Rehabilitation Nursing 2006; 31(1):10-14

Rampello 2004 \{published data only\}

Rampello L, Chiechio S, Nicoletti G, Alvano A,

Vecchio I, Raffaele R, et al.Prediction of the response to citalopram and reboxetine in post-stroke depressed patients. Psychopharmacology 2004;173:73-8.
Ricauda 2004 \{published data only\}

Ahrens J. Italian study concludes "home hospitalization" benefits stroke patients. Caring: National Association for Home Care magazine 2004;23(8):40-2.

Barale S, Tibaldi V, Isaia G, Stasi MF, Marinello R, Massaia $\mathrm{M}$, et al.Acute ischaemic cerebral stroke in older patients. Two year follow-up. Proceedings of the Italian Stroke Forum - Stroke 2004. Italy, Florence, 7-9 March 2004:81. Leff B, Montalto M. Home hospital -- toward a tighter definition. Journal of the American Geriatrics Society 2004; 52:2141

* Ricauda NA, Bo M, Molaschi M, Massaia M, Salerno D, Amati D, et al.Home hospitalization service for acute uncomplicated first ischemic stroke in elderly patients: a randomized trial. Journal of the American Geriatrics Society 2004;52:278-83

Ricauda NA, Tibaldi V, Marinello R, Bo M, Isaia G, Scarafiotti $\mathrm{C}$, et al.Acute ischemic stroke in elderly patients treated in hospital at home: a cost minimization analysis. Journal of the American Geriatrics Society 2005;53(8): 1442-3.

\section{Roberts 1995 \{published data only\}}

Roberts J, Browne GB, Streiner D, Gafni A, Pallister R, Hoxby $\mathrm{H}$, et al.Problem-solving counselling or phone-call support for outpatients with chronic illness: effective for whom?. Canadian Journal of Nursing Research 1995;27(3): 111-37.

Rodgers 1999 \{published data only\}

Rodgers H, Atkinson C, Bond S, Suddes M, Dobson R, Curless R. Randomized controlled trial of a comprehensive stroke education program for patients and caregivers. Stroke 1999;30(12):2585-91.

Rudd 1997 \{published data only\}

Rudd AG, Wolfe CDA, Tilling K, Beech R. Randomised controlled trial to evaluate early discharge scheme for patients with stroke. BMJ 1997;315(7115):1039-44.

\section{Rønning 1998 \{published data only\}} Rønning OM, Guldvog B. Outcome of subacute stroke rehabilitation: a randomized controlled trial. Stroke 1998; 29(4):779-84

Sandberg 2001 \{published data only\}

Sandberg O, Franklin KA, Bucht G, Eriksson S, Gustafson Y. Nasal continuous positive airway pressure in stroke patients with sleep apnoea: a randomized treatment study. European Respiratory Journal 2001;18(4):630-4.

Seliger 1990 \{published data only\} Seliger GM, Herbert J, Hornstein A, Flax J, Schroeder K, Guarracini M. Fluoxetine improves pseudobulbar affect. Neurology 1990; Vol. 40, issue Suppl 1:327.

Shan 2001 \{published data only\} Shan P-Y, Liu S-P, Chi Z-F. Effect of fluoxetine on treatment of post-stroke depression. Acta Academiae Medicinae Shandong 2001;39(3):229-33.

Sivenius 2001 \{published data only\} Sivenius J, Sarasoja T, Aaltonen H, Heinonen E, Kilkku O, Reinikainen K. Selegiline treatment facilitates recovery 
after stroke. Journal of Neurologic Rehabilitation 2001;15 (3):183-90.

\section{Smedley 1986 \{published data only\}}

Smedley RR, Fiorino AJ, Soucar E, Reynolds D, Smedley WP, Aronica MJ. Slot machines their use in rehabilitation after stroke. Archives of Physical Medicine and Rehabilitation 1986;67(8):546-9.

Smith 2004 \{published data only\}

Smith J, Forster A, Young J. A randomized trial to evaluate an education programme for patients and carers after stroke. Clinical Rehabilitation 2004;18:726-36.

Song 1999 \{published data only\}

Song Y, Liang H. Observation of the curative effect of scalp-acupuncture on cerebral postapoplectic depression. Shanghai Journal of Acupuncture and Moxibustion 1999;18 (1):8-9.

Su 2004 \{published data only\}

$\mathrm{Su}$ X-L, Xiao X-C. Effect of psychotherapy on the motor functional rehabilitation in patients with post stroke depression. Zhongguo Linchuang Kangfu 2004;8:3720-1.

Sulch 2000 \{published data only\}

Sulch D, Perez I, Melbourn A, Kalra L. Randomized controlled trial of integrated (managed) care pathway for stroke rehabilitation. Stroke 2000;31:1929-34.

Sulch 2002 \{published data only\}

Sulch D, Melbourn A, Perez I, Kalra L. Integrated care pathways and quality of life on a stroke rehabilitation unit. Stroke 2002;33:1600-4.

Suskin 2006 \{published data only\}

Suskin N, Hachinski V, Chan R, Prior PL, Unsworth KL, Mytka S, et al.Multidisciplinary cardiac rehabilitation for secondary prevention after TIA or mild nondisabling stroke: vascular risk factors, psychological and neurocognitive outcomes. International Journal of Stroke 2006;1 Suppl 1:91.

Suzuki 2001 \{published data only\}

Suzuki H, Eto F, Furuichi T, Ohtsuru I, Saotome I.

Facilitative effect of aniracetam on rehabilitation of poststroke patients. The 1st World Congress of the International Society of Physical Rehabilitation Medicine (ISPRM I). The Netherlands, Amsterdam, 7-13 July 2001: 511-6.

Tan 2004 \{published data only\}

Tan Y, Liang L, Li S, Zhong C. Effects of mental nursing on the patients with geriatric cardiovascular and cerebrovascular diseases. Chinese Journal of Clinical Psychology 2004;12(2): 201-2.

Taragano 2001 \{published data only\}

* Taragano FE, Allegri R, Vicario A, Bagnatti P, Lyketsos CG. A double blind, randomized clinical trial assessing the efficacy and safety of augmenting standard antidepressant therapy with nimodipine in the treatment of 'vascular depression'. International Journal of Geriatric Psychiatry 2001;16(3):254-60.

Taragano FE, Bagnatti P, Allegri RF. A double-blind, randomized clinical trial to assess the augmentation with nimodipine of antidepressant therapy in the treatment of "Vascular depression". International psychogeriatrics 2005; 17:487-98.

\section{Wade 1992 \{published data only\}}

Wade DT, Collen FM, Robb GF, Warlow CP. Physiotherapy intervention late after stroke and mobility. British Medical Journal 1992;304(6827):609-13.

Walker-Batson 1995 \{published data only\}

Walker-Batson D, Smith P, Curtis S, Unwin H, Greenlee R. Amphetamine paired with physical therapy accelerates motor recovery after stroke: further evidence. Stroke 1995; 26(12):2254-9.

Walsh 1999 \{published data only\}

Walsh E, Wilson C. Complementary therapies in long-stay neurology in-patient settings. Nursing Standard 1999;13 (32):32-5.

\section{Wang 2002 \{published data only\}}

Wang F, Dong X, Pan Y, Liu M. Effect of yukangning in the treatment of post stroke depression and nerve function recovery. Chinese Journal of Clinical Rehabilitation 2005;7 (7): 1225 .

Wang 2003 \{published data only\}

Wang X, Tan Z, Wu Z, Gao J, Feng M. The effects of antidepression therapy on post-stroke depression and neurologic rehabilitation in the elderly patients. Chinese Journal of Geriatrics 2003;22(5):270-3.

Wang 2004 \{published data only\}

Wang H, Geng D. Effects of paroxetine treating nervous function recovery and depression after stroke. Nervous Diseases and Metal Hygiene 2004;4(1):36-7.

Wang 2007 \{published data only\}

Wang W, Zhao Y, Wu Y. The clinical effects of YiYu III in treating post-stroke depression. Clinical Journal of Rehabilitation Theory and Practice 2007;13(3):292.

Werner 1996 \{published data only\}

Werner RA, Kessler S. Effectiveness of an intensive outpatient rehabilitation program for postacute stroke patients. American Journal of Physical Medicine \& Rehabilitation 1996;75(2):114-20.

Wheeler 2003 \{published data only\}

Wheeler BL, Shiflett SC, Nayak S. Effects of number of sessions and group or individual music therapy on the mood and behavior of people who have had strokes or traumatic brain injuries. Nordic Journal of Music Therapy 2003;12(2): 139-51.

Wiart 1997 \{published data only\}

Wiart L. Post-cerebrovascular stroke depression. L'Encephale 1997;23 (Suppl III):51-4.

Williams 2002 \{published data only\}

Plue L. Treatment for post-stroke depression. http:/ /www.clinicaltrials.gov [electronic database] 2003. [: NCT002966140]

Williams L. AIM: a randomised trial of treatment for poststroke depression. Stroke Trials Directory, Internet Stroke 
center 2003:www.strokecenter.org/trials/list.

* Williams LS, Kroenke K, Bakas T, Plue LD, Brizendine E,

Tu W, et al.Care management of poststroke depression: a randomized, controlled trial. Stroke 2007;38:998-1003. Williams LS, Kroenke K, Plue L, Bakas T, Hendrie H, Biller J. AIM: a randomized trial of treatment for post-stroke depression. 27th International Stroke Conference. 2002; Vol. 33, issue 1:254-60.

Williams LS, Kroenke K, Plue L, Bakas T, Tu W, Shen J, et al.AIM: a randomized trial of treatment for post-stroke depression. Proceedings of the 28th International Stroke Conference. USA, Phoenix, Arizona: The American Stroke Association, 13-15 February 2003.

\section{Wolfe 2000 \{published data only\}}

Wolfe CDA, Tilling K, Rudd AG. The effectiveness of community-based rehabilitation for stroke patients who remain at home: a pilot randomized trial. Clinical Rehabilitation 2000;14(6):563-9.

Wu 2002 \{published data only\}

Wu J-X. An observation of Bai-You-Jie treating poststroke depression and nervous function impairment. Journal of Clinical Neurology 2002;15(2):124-5.

Xia 2003 \{published data only\}

Xia WM, Hu YQ. Effect of early psychological intervention in rehabilitation of patients with cerebral stroke. Chinese Journal of Clinical Rehabilitation 2003;7(28):3842-3.

Xiaoying 2001 \{published data only\}

Xiaoying HE. Approaches to the treatment methods of post stroke depression. Modern Rehabilitation 2001;5:8.

Xie 2003 \{published data only\}

Xie S, Zhu M, Cui H, Liu H. Influence of early psychological intervention on mental health in hemiplegias after stroke. Chinese Journal of Clinical Rehabilitation 2003; 7(7):1208-9.

Xie 2005 \{published data only\}

* Xie R, Liu J, Quan H, Wang D, Luo M. A prospective random clinical contrast study of treatment with sertraline in elderly patients with post-stroke depression. Chinese Journal of Clinical Neurosciences 2005;13(3):294-7.

Xie R, Liu J, Quan J, Wang D, Luo M, Chen W. A prospective random clinical contrast study of treatment with Sertraline in elderly patients with post-stroke depression. Chinese Journal of Geriatric Care 2006;4(3):44-7.

Xing 1999 \{published data only\}

Xing Y-G, Tao E-X. The effect of fluoxetine on the recovery of poststroke depression. Chinese Journal of Nervous and Mental Disorders 1999;25(4):231-2.

Xu 2001 \{published data only\}

$\mathrm{Xu} \mathrm{J}$, Tan J, Ou L. A study on treatment of fluoxetine to depression in early recovery stage of cerebral infarction. Chinese Journal of Rehabilitation Medicine 2001;16(5): 281-3.

Ye 2004 \{published data only\}

Ye LX, Wang H, Wang YD, Zhang L, Liang DS, Guo

Y. Effect of anti-depressive therapy on the rehabilitation of psychological and neurological function after stroke. Chinese Journal of Clinical Rehabilitation 2004;8(31): 6826-8.

Yi 1990 \{published data only\}

Yi SD, Park YC, Yoo KM. Effects of indeloxazine $\mathrm{HCl}$ on the chronic stage of stroke. Keimyung University Medical Journal 1990;9(3):336-9.

Yokokawa 1991 \{published data only\}

Yokokawa Y, Minamisawa H, Sato H, Kai I, Nakajima T, Fukusima Y. Psychological effect of a physical activity program on community people with cerebral apoplexy. Proceedings of the 13th International Congress of the World Confederation of Physical Therapy. Japan, Yokohama, 23-28 May 1991:559.

Yoneyama 1993 \{published data only\}

Yoneyama K, Saito K, Kamo T, Iwasaki M, Horiuchi M, Narita N, et al.Effects of indeloxazine hydrochloride on activities of daily living in cerebrovascular disease: evaluation by accelerometer. Current Therapeutic Research 1993;54(4):413-9.

You 2002 \{published data only\}

You C-K. The effect of depression after acute stroke interventions on the recovery of motor function. Chinese Journal of Clinical Rehabilitation 2002;6(17):2557.

Young 1992 \{published data only\}

Young J, Forster A. The Bradford community stroke trial: results at six months. BMJ 1992;304:1085-9.

Yu 1991 \{published data only\}

Yu LC, Johnson KL, Kalreider L, Craighead WE, Hu T-W. The relationship between depression, functional status, and cognitive status among institutionalized elderly women. Behavior, Health, and Aging 1993;3(1):23-32.

* Yu LC, Kaltreider L, Hu T-W, Craighead WE. Impact of a behavior therapy on the psychological status of incontinent elderly nursing home residents: quantitative and qualitative assessment. In: Myers WA editor(s). New Techniques in the Psychotherapy of Older Patients. Washington DC: American Psych Press, 1991:181-202.

Yu LC, Rohner TJ, Kaltreider L, Hu T-W, Igou JF, Dennis PJ. Profile of urinary incontinent elderly in long-term institutions. Journal of the American Geriatrics Society 1990; 38:433-9.

Zhang 2000 \{published data only\} Zhang S-M, Ma J, Cheng J-M. Clinical research of paroxetine treating post stroke depression. Chinese Journal of Nervous and Mental Disorders 2001;6:430-2.

Zhang 2002 \{published data only\}

Zhang L-s, Chen Z-M, Wei R-h. Paroxetine vs imipramine in treatment of post-stroke depressive disorder. Zhongguo Xinyao Yu Linchuang Zazhi 2002;21(1):9-11.

Zhang 2002a \{published data only\}

Zhang P, Bai W, Wang G, Shi Y, Du Y, Qi Y, et al.Effects of treating post-stroke depression on recovery prognosis of early stage. Chinese Journal of Clinical Rehabilitation 2002;6 (1):32-3.

Interventions for treating depression after stroke (Review)

Copyright (C) 2008 The Cochrane Collaboration. Published by John Wiley \& Sons, Ltd. 
Zhang 2002b \{published data only\}

Zhang L-H, Shi X-Y, Wang X-Q. The effect of fluoxetine on poststroke depression and nervous function recovery. Chinese Journal of Clinical Rehabilitation 2002;6(11):1602.

Zhang 2005 \{published data only\}

Zhang YX, Zhang HL, Wang H. Effects of buspirone hydrochloride on post-stroke affective disorder and neural function. Chinese Journal of Clinical Rehabilitation 2005;9 (12):8-9.

\section{Zhang 2005a \{published data only\}}

Zhang C. The brain-resuscitation acupuncture method for treatment of post wind-stroke mental depression: a report of 45 cases. Journal of Traditional Chinese Medicine 2005; 25:243-6.

Zhao 1999 \{published data only\}

Zhao M, Wang ZM, Wang X, Ma JD. The therapeutic observation of fluoxetine single or combined with psychotherapy in the depression succeeding brain stroke. Health Psychology Journal 1999;7(3):241-3.

Zhao 2005 \{published data only\}

Zhao FT, Xu SM, Zhang QH, Wang XL, Liu HH.

Citalopram versus venlafaxine for the improvement of poststroke depression. Chinese Journal of Clinical Rehabilitation 2005;9(12):12-3.

Zhao 2005a \{published data only\}

Zhao S, Jia X. Comparative study of the effects of citalopram and amitriptyline on post stroke depression. Journal of Linyi Medical College 2005;27:329-31.

Zhou 2003 \{published data only\}

Zhou B. Xiao J, Wu J, Yuan Q, Yang Y. Effects of fluoxetine on neurofunctional recovery of nondepressed patients after stroke. Chinese Journal of Clinical Rehabilitation 2003;7(3): 374-5.

Zhou 2004 \{published data only\}

$\mathrm{Su}$ X-L, Xiao X-C. Effect of psychotherapy on the motor functional rehabilitation in patients with post-stroke depression. Chinese Journal of Clinical Rehabilitation 2004; 8(19):3720-1.

* Zhou C-X, Su X-L, Yang X-Z, Xiao X-C, Zhao H-W. Effect of psychological nursing on the rehabilitation of poststroke depression. Chinese Journal of Clinical Rehabilitation 2004;8(16):3008-9.

Zhu 2002 \{published data only\}

Zhu G-H, Yao J-L. The effect of fluoxetine on poststroke depression and nervous function recovery. Chinese Journal of Clinical Rehabilitation 2002;6(3):366-7.

Zifko 2002 \{published data only\}

Zifko UA, Rupp M, Schwarz S. Sertraline in the treatment of post-stroke depression: results of an open multicenter study [Sonderkrankenanstalt fur neurologie der rehabilitationsklinik pirawarth, arbeitskreises fur klinische forschung in der neurorehabilitation, bad pirawarth]. Wiener Medizinische Wochenshrift 2002;152(13-14):343-8.

\section{References to studies awaiting assessment}

\section{Atarashi 1979 \{published data only\}}

Atarashi J, Araki GITO, Hitoshi O, Eiichi KM, Masakuni $\mathrm{K}$. Clinical evaluation of cinepazide in the treatment of cerebrovascular disorders: multi-center double-blind study in comparison with placebo. Rinsho Hyoka (Clinical Evaluation) 1979;7(2):349-77.

Evans 1985 \{published data only\} Evans RL, Kleinman L, Halar EM, Herzer K. Predicting outcome of group counselling with severely disabled patients. American Journal of Physical Medicine 1985;64(1): 24-31.

Hanspal 2007 \{published data only\} Hanspal R. The effectiveness of sertraline in clinical management of depression with or without lability in braininjured. National Research Register. [: N0388126828]

Katz 1998 \{published data only\} Katz RA, Hubbard DJ, Blaine J. The effect of group psychotherapy on post-stroke depression. Rehabilitation Psychology 1998;43(2):178.

Latow 1983 \{published data only\}

Latow J. Psychotherapy and its effect on depression, sickrole identification and rehabilitation outcome for stroke victims. Archives of Physical Medicine and Rehabilitation 1983;64(10):511-2.

Otomo 1986 \{published data only\}

Otomo E, Tohgi H, Hirai S, Gotoh F, Hasegawa K, Tazaki $\mathrm{Y}$, et al.Clinical evaluation of YM-08054 (indeloxazine) in the treatment of cerebrovascular disorder. Igaku no Ayumi 1986;136(7):535-55.

Wang 2005 \{published data only\}

Wang ZM, Wang P, You LL. Study of effects of fluoxetine in patients with post-stroke depression, a random placebocontrolled study. Chinese Journal of Practical Neurology 2005; Vol. 8:80-1.

Yamamoto 1999 \{published data only\}

Yamamoto T, Nishimura R, Takagi T. Importance of a psychological approach to the chronic cerebral vascular accident patient. Proceedings of the 13th international congress of the world confederation of physical therapy. Japan, Yokohama, 1999 May 23-28:598.

\section{References to ongoing studies}

\section{Graven 2008 \{published data only\}}

Graven C. From rehabilitation to recovery: a model to optimise consumer and carer involvement in the first year post stroke. Australian New Zealand Clinical Trials Registry 2008. [: ACTRN12608000042347]

Mitchell 2002 \{published data only\}

Mitchell P, Becker K, Cramer S, Teri L, Tirshwell D, Veith R. Psychosocial/Behavioral Intervention in Post Stroke Depression (PSD). www.strokecenter.org/trials. Mitchell PH, Veith R, Cain KC. Living well with stroke: psychosocial-behavioural intervention in post-stroke depression. Proceedings of the International Stroke 
Conference. USA, New Orleans, Louisiana: American Stroke Association, 2 February 2005:Abst. CTP39.

Thomas 2007 \{published data only\}

Thomas S, Kontou E, Walker M, Lincoln N, Haworth

$\mathrm{H}$, Macniven J. CALM: Communication and low mood.

National Reserach Register. [: N0192165295]

\section{Additional references}

\section{Anderson 1995a}

Anderson CS, Linto J, Stewart-Wynne EG. A populationbased assessment of the impact and burden of caregiving for long-term stroke survivors. Stroke 1995;26:843-9.

\section{APA 1987}

American Psychiatric Association. Diagnostic and statistical manual of mental disorders: DSM-III-R. Washington, DC: American Psychiatric Association, 1987.

\section{APA 1994}

American Psychiatric Association. Diagnostic and statistical manual of mental disorders: DSM-IV. Washington, DC: American Psychiatric Association, 1994.

\section{Astrom 1996}

Astrom M. Generalized anxiety disorder in stroke patients: a 3-year longitudinal study. Stroke 1996;27:270-5.

\section{Beck 1961}

Beck AT, Ward C, Mendelson M. An inventory for measuring depression. Archives of General Psychiatry 1961; 4:561-71.

\section{Burvill 1995a}

Burvill PW, Johnson GA, Jamrozik KD, Anderson CS, Stewart-Wynne EG, Chakera TM. Prevalence of depression after stroke: the Perth Community Stroke Study. British Journal of Psychiatry 1995;166:320-7.

\section{Burvill 1996}

Burvill PW, Johnson GA, Chakera TMH, Stewart-Wynne EG, Anderson CS, Jamrozik KD. The place of site of lesion in the aetiology of post-stroke depression. Cerebrovascular Diseases 1996;6:208-15.

\section{Burvill 1997}

Burvill P, Johnson G, Jamrozik KD, Anderson C. Risk factors for post-stroke depression. International Journal of Geriatric Psychiatry 1997;12:219-26.

\section{Carson 2000}

Carson AJ, MacHale S, Allen K, Lawrie SM, Dennis M, House A, et al.Depression after stroke and lesion location: a systematic review. Lancet 2000;356:122-6.

\section{Chan 2004}

Chan A, Hrobjartsson A, Haahr MT, Gotzsche PC, Altman DG. Empirical evidence for selective reporting of outcomes in randomized trials: comparison of protocols to published articles. Journal of the American Medical Association 2004; 291:2457-65.

\section{Deutsch 1997}

Deutsch A, Braun S, Granger CV. The Functional Independence Measure (FIM Instrument). Journal of Rehabilitation Outcomes Measures 1997;1:67-71.

\section{Duval 2000}

Duval S, Tweedie R. Trim and fill: a simple funnel-plotbased method of testing and adjusting for publication bias in meta-analysis. Biometrics 2000;56(2):455-63.

\section{Ebrahim 1987a}

Ebrahim S, Barer D, Nouri F. Affective illness after stroke. British Journal of Psychiatry 1987;151:52-6.

\section{Folstein 1975}

Folstein MF, Folstein SE, McHugh PR. 'Mini-Mental State': a practical method for grading the cognitive state of patients for the clinician. Journal of Psychiatric Research 1975;12: 189-98.

Gill 2000

Gill D, Hatcher S. Antidepressants for depression in medical illness. Cochrane Database of Systematic Reviews 2001, Issue 3. [Art. No.: CD001312. DOI: 10.1002/ 14651858.CD001312.pub2]

\section{Goldberg 1972}

Goldberg DP. The detection of psychiatric illness by questionnaire. Vol. Maudsley Monograph No. 21, Oxford: Oxford University Press, 1972.

\section{Gompertz 1993}

Gompertz P, Pound P, Ebrahim S. The reliability of stroke outcome measurement. Clinical Rehabilitation 1993;7: 290-6

\section{Hackett 2005a}

Hackett ML, Yapa C, Parag V, Anderson CS. Frequency of depression after stroke: a systematic review of observational studies. Stroke 2005;36:1330-40.

\section{Hackett 2008}

Hackett ML, Anderson CS, House A, Halteh C. Interventions for preventing depression after stroke. Cochrane Database of Systematic Reviews 2008, Issue 3. [Art. No.: CD003689. DOI: 10.1002/ 14651858.CD003689.pub2]

\section{Hamilton 1960}

Hamilton M. Rating scale for depression. Journal of Neurology, Neurosurgery and Psychiatry 1960;23:56-62.

\section{Herrmann 1998}

Herrmann N, Backe SE, Lawrence J, Szekely C, Szalai JP. The Sunnybrook stroke study: a prospective study of depressive symptoms and functional outcome. Stroke 1998; 29:618-24.

\section{Hollis 1999}

Hollis S, Campbell F. What is meant by intention to treat analysis? Survey of published randomised controlled trials. British Medical Journal 1999;319:670-4.

\section{House 1987}

House A. Mood disorders after stroke: a review of the evidence. International Journal of Geriatric Psychiatry 1987; 2:211-21.

House 1989

House A, Dennis M, Hawton K, Warlow C. Methods of identifying mood disorders in stroke patients: experience in 
the Oxfordshire community stroke project. Age and Aging 1989;18:371-9.

\section{House 1991}

House A, Dennis M, Mogridge L, Warlow C, Hawton K, Jones L. Mood disorders in the year after first stroke. British Journal of Psychiatry 1991;158:83-92.

\section{House 2001}

House A, Knapp P, Bamford J, Vail A. Mortality at 12 and 24 months after stroke may be associated with depressive symptoms at 1 month. Stroke 2001;32:696-701.

Hunt 1986

Hunt SM, McEwan J, McKenna SP. Measuring Health Status. Beckenham: Croom Helm, 1986.

\section{ICH 1999}

Annonymous. ICH Harmonised tripartite guideline: statistical principles for clinical trials. Statistics in Medicine 1999;18:1905-42.

\section{Johnson 1991}

Johnson GA. Research into psychiatric disorder after stroke: the need for further studies. Australian \& New Zealand Journal of Psychiatry 1991;25:358-70.

Katona 1995

Katona CLE, Watkin V. Depression in old age. Reviews in Clinical Gerontology 1995;5:427-41.

\section{Keller 2003}

Keller MB. Past, present, and future directions for defining optimal treatment outcome in depression: remission and beyond. Journal of the American Medical Association 2003; 289(23):3152-60.

\section{Kirsch 2008}

Kirsch I, Deacon BJ, Huedo-Medina TB, Scoboria A, Moore TJ, Johnson BT. Initial severity and antidepressant benefits: a meta-analysis of data submitted to the Food and Drug Administration. PLoS Medicine 2008;5(2):0260-8.

\section{Lima 2001}

Lima MS, Moncrieff J. Drugs versus placebo for dysthymia. Cochrane Database of Systematic Reviews 2001, Issue 3. [Art. No.: CD001130. DOI: 10.1002/14651858.CD001130]

\section{Mahoney 1965}

Mahoney FI, Barthel DW. Functional evaluation: the Barthel Index. Maryland State Medical Journal 1965;14: 61-5.

\section{McCusker 1998}

McCusker J, Cole M, Keller E, Bellavance F, Berard A. Effectiveness of treatments of depression in older ambulatory patients. Archives of Internal Medicine 1998; 158:705-12.

\section{Mittmann 1997}

Mittmann N, Herrmann N, Einarson TR, Busto UE, Lanctot KL, Liu BA, et al.The efficacy, safety and tolerability of antidepressants in late life depression: a meta-analysis. Journal of Affective Disorders 1997;46:191-217.

\section{Moher 2003}

Moher D, Schulz KF, Altman DG, CONSORT Group. The CONSORT statement: revised recommendations for improving the quality of reports of parallel-group randomised trials. Clinical Oral Investigations 2003;7(1): $2-7$.

\section{Montgomery 1979}

Montgomery SA, Asberg M. A new depression scale designed to be sensitive to change. British Journal of Psychiatry 1979;134:382-9.

\section{Morris 1993b}

Morris PL, Robinson RG, Andrzejewski P, Samuels J, Price TR. Association of depression with 10-year poststroke mortality. American Journal of Psychiatry 1993;150:124-9.

\section{Normand 1999}

Normand ST. Meta-analysis: formulating, evaluating, combining, and reporting. Statistics in Medicine 1999;18: $321-59$.

\section{Parikh 1990}

Parikh RM, Robinson RG, Lipsey JR, Starkstein SE, Fedoroff JP, Price TR. The impact of poststroke depression on recovery in activities of daily living over a 2-year followup. Archives of Neurology 1990;47:785-9.

\section{Rankin 1957}

Rankin J. Cerebral vascular accidents in people over the age of 60. II. Prognosis. Scottish Medical Journal 1957;2: $200-15$.

\section{Robinson 1986}

Robinson RG, Bolla-Wilson K, Kaplan E, Lipsey JR, Price TR. Depression influences intellectual impairment in stroke patients. British Journal of Psychiatry 1986;148:541-7.

\section{Sharpe 1990}

Sharpe M, Hawton K, House A, Molyneux A, Sandercock P, Bamford J, et al.Mood disorders in long-term survivors of stroke: associations with brain lesion location and volume. Psychological Medicine 1990;20:815-28.

\section{Sinyor 1986}

Sinyor D, Amato P, Kaloupek DG, Becker R, Goldenberg M, Coopersmith H. Post-stroke depression: relationships to functional impairment, coping strategies, and rehabilitation outcome. Stroke 1986;17:1102-7.

Snow 2000

Snow V, Lascher S, Mottur-Pilson C, for the American College of Physicians-American Society of Internal Medicine. Pharmacologic treatment of acute major depression and dysthymia. Annals of Internal Medicine 2000;132(9):738-42.

\section{Stenager 1998}

Stenager EN, Madsen C, Stenager E, Boldsen J. Suicide in patients with stroke: epidemiological study. British Medical Journal 1998;316:1206.

\section{Turner-Stokes 2003}

Turner-Stokes L. Poststroke depression: getting the full picture. Lancet 2003;361(9371):1757-8.

\section{Verhagen 2001}

Verhagen AP, de Vet HCW, de Bie RA, Boers M, van den Brandt PA. The art of quality assessment of RCTs included 
in systematic reviews. Journal of Clinical Epidemiology 2001; 54:651-4.

\section{Wade 1985}

Wade DT, Leigh-Smith J, Langton Hewer R. Social activities after stroke: measurement and natural history using the Frenchay Activities Index. International Rehabilitation Medicine 1985;4:176-81.

\section{Ware 1993}

Ware JE, Snow KK, Kosinski M, Gandek B. SF-36 Health Survey: Manual and Interpretation Guide. Boston, Mass: New England Medical Center, Health Institute, 1993.

Wilkinson 1997

Wilkinson P. Cognitive therapy with elderly people. Age and Ageing 1997;26:53-8.

Zigmond 1983

Zigmond AS, Snaith RP. The Hospital Anxiety and Depression Scale. Acta Psychiatrica Scandinavica 1983;67: 361-70.

\section{Zimmerman 2002}

Zimmerman M, Mattia JI, Posternak MA. Are subjects in pharmacological treatment trials of depression representative of patients in routine clinical practice?. American Journal of Psychiatry 2002;159(3):469-73.

\section{References to other published versions of this review}

\section{Hackett 2004}

Hackett ML, Anderson CS, House AO. Interventions for treating depression after stroke.. Cochrane Database of Systematic Reviews 2004, Issue 3. [Art. No.: CD003437. DOI: $10.1002 / 14651858 . C D 003437 . p u b 2]$

\section{Hackett 2005}

Hackett ML, Anderson CS, House AO. Management of depression after stroke: a systematic review of pharmacological therapies. Stroke 2005;36:1092-7.

* Indicates the major publication for the study 
CHARACTERISTICS OF STUDIES

\section{Characteristics of included studies [ordered by study ID]}

Andersen 1994

\begin{tabular}{|c|c|c|}
\hline Methods & \multicolumn{2}{|c|}{$\begin{array}{l}\text { Parallel design } \\
\text { Method of randomisation: blocks of } 4 \text { used } \\
\text { Method of concealment: centralised, opaque envelopes } \\
\text { Blinding: double-blind reported, those blinded not stated } \\
\text { Analysis: ITT (last observation carried forward) and per protocol: death (1 treatment, } 1 \text { control), with- } \\
\text { drawn due to AE ( } 6 \text { treatment, } 1 \text { control), all excluded from analysis }\end{array}$} \\
\hline Participants & \multicolumn{2}{|c|}{$\begin{array}{l}\text { Location: Denmark } \\
\text { Setting: mixed } \\
\text { Treatment: } 33 \text { ( } 36 \% \text { male, mean age } 68 \text { years, SD 4) } \\
\text { Control: } 33 \text { ( } 66 \% \text { male, mean age } 66 \text { years, SD 9) } \\
\text { Stroke criteria: ischaemic stroke and primary intracerebral haemorrhage; diagnosis via clinical signs and } \\
\text { CT ( } 100 \%) \text {; stroke } 2 \text { to } 52 \text { weeks prior to randomisation (average time } 12 \text { weeks) } \\
\text { Depression criteria: HDRS score > } 12 \text { (score transformed to appropriate DSM-III-R criteria) } \\
\text { Other entry criteria: none stated } \\
\text { Comparability of treatment groups: balanced }\end{array}$} \\
\hline Interventions & \multicolumn{2}{|c|}{$\begin{array}{l}\text { Treatment: citalopram, } 10 \mathrm{mg} \text { in participants }>66 \text { years, } 20 \mathrm{mg} \text { in participants }<67 \text { years, daily; dose } \\
\text { doubled if no response to treatment within } 3 \text { weeks } \\
\text { Control: matched placebo } \\
\text { Duration: treatment continued for } 6 \text { weeks }\end{array}$} \\
\hline Outcomes & \multicolumn{2}{|c|}{$\begin{array}{l}\text { Depression: change in scores from baseline to end of treatment on HDRS* } \\
\text { Melancholia Scale } \\
\text { Proportion no longer meeting entry criteria (<13 on HDRS) } \\
50 \% \text { reduction in HDRS score } \\
\text { Additional: leaving the study early } \\
\text { Death } \\
\text { Adverse events } \\
\text { Unable to use: BI, Social Activities Index, MMSE (data not presented) }\end{array}$} \\
\hline Notes & \multicolumn{2}{|c|}{$\begin{array}{l}\text { Exclusion criteria: depression within last year, receiving current treatment for depression, severe dementi } \\
\text { or communication problems, degenerative or expansive neurological disease, decreased consciousness }\end{array}$} \\
\hline \multicolumn{3}{|l|}{ Risk of bias } \\
\hline Item & Authors' judgement & Description \\
\hline Allocation concealment? & Yes & A - Adequate \\
\hline
\end{tabular}


Fruehwald 2003

\begin{tabular}{|c|c|c|}
\hline Methods & \multicolumn{2}{|c|}{$\begin{array}{l}\text { Parallel design } \\
\text { Method of randomisation: permuted block design } \\
\text { Method of concealment: centralised } \\
\text { Blinding: double blind } \\
\text { Participants: yes } \\
\text { Relatives: yes } \\
\text { Clinical examiners: yes } \\
\text { Nursing staff: yes } \\
\text { Analysis: per protocol: death ( } 1 \text { treatment), withdrawn due to AE ( } 1 \text { treatment, } 2 \text { control), all excludec } \\
\text { from analysis }\end{array}$} \\
\hline Participants & \multicolumn{2}{|c|}{$\begin{array}{l}\text { Location: Austria } \\
\text { Setting: inpatients } \\
\text { Treatment: } 28 \text { ( } 46 \% \text { male, mean age } 65 \text { years, SD 14) } \\
\text { Control: } 26 \text { ( } 71 \% \text { male, mean age } 64 \text { years, SD 14) } \\
\text { Stroke criteria: ischaemic stroke and primary intracerebral haemorrhage; diagnosis via clinical signs and } \\
\text { CT (100\%); stroke on average } 11 \text { days prior to randomisation } \\
\text { Depression criteria: psychiatric interview, HDRS score > } 15 \\
\text { Other entry criteria: none stated } \\
\text { Comparability of treatment groups: non-significant trend towards more females and right-sided lesion } \\
\text { strokes in treatment group }\end{array}$} \\
\hline Interventions & \multicolumn{2}{|c|}{$\begin{array}{l}\text { Treatment: fluoxetine } 20 \mathrm{mg} \text {, daily; dose escalation at } 4 \text { weeks if HDRS score }>13 \\
\text { Control: matched placebo } \\
\text { Duration: treatment continued for } 12 \text { weeks }\end{array}$} \\
\hline Outcomes & \multicolumn{2}{|c|}{$\begin{array}{l}\text { Depression: change in scores from baseline to end of treatment on HDRS, BDI and Clinical Global } \\
\text { Impression Scale (Item 1) } \\
\text { Proportion of responders (<13 HDRS) } \\
\text { Additional: Scandinavian Stroke Scale } \\
\text { Death } \\
\text { Adverse events (selected data) } \\
\text { Unable to use: RS, BI, MMSE (data not presented at follow up) } \\
\text { Adverse events data on dizziness, nausea and cephalalgia (data not presented by group) }\end{array}$} \\
\hline Notes & \multicolumn{2}{|c|}{$\begin{array}{l}\text { Exclusion criteria: MMSE }<20 \text {, more than mild communication deficit, diseases of the CNS and previous } \\
\text { degenerative or expansive neurological disorders }\end{array}$} \\
\hline \multicolumn{3}{|l|}{ Risk of bias } \\
\hline Item & Authors' judgement & Description \\
\hline Allocation concealment? & Yes & A - Adequate \\
\hline
\end{tabular}




\begin{tabular}{l|l}
\hline Methods & Parallel design \\
Method of randomisation: randomised stated, method unclear \\
Method of concealment: unclear \\
Blinding: single blind reported \\
Participants: yes \\
Investigators: no \\
Outcome assessors: unclear \\
Analysis: ITT (no drop outs)
\end{tabular}

\section{Risk of bias}

\begin{tabular}{l|ll}
\hline Item & Authors' judgement & Description \\
\hline Allocation concealment? & Unclear & B - Unclear \\
\hline
\end{tabular}

\section{Jiang 2001b}

\begin{tabular}{ll}
\hline Methods & Parallel design \\
& Method of randomisation: randomised stated, method unclear \\
& Method of concealment: unclear \\
& Blinding: single blind reported \\
& Participants: yes \\
& Investigators: no \\
& Outcome assessors: unclear \\
& Analysis: ITT \\
\hline Participants & Location: China \\
& Setting: inpatient \\
& Treatment: 30 (58\% male, mean age 62 years, SD 14) \\
\hline
\end{tabular}


Control: 15 (60\% male, mean age 63 years, SD 15)

Stroke criteria: unclear, diagnosis via CT or MRI (100\%); stroke 0 to 7 days prior to randomisation

Depression criteria: HDRS $>8$

Other entry criteria: Chinese stroke scale score $>8$, can independently complete assessment scale, aged < 80 years, no severe negative life events in past year, first stroke, no previous psychosis or antidepressant medication

Comparability of treatment groups: intervention group younger, higher HDRS score and lower CSS score

\begin{tabular}{ll}
\hline Interventions & Treatment: Deanxit 2 tablets daily \\
& Control**: placebo (not matched but frequency matched) $^{*}$ \\
& Duration: treatment continued for 6 months \\
\hline
\end{tabular}

Outcomes Depression: change in scores from baseline to end of treatment on HDRS

Additional: adverse events, CSS

\section{Notes}

\section{Risk of bias}

\begin{tabular}{l|ll}
\hline Item & Authors' judgement & Description \\
\hline Allocation concealment? & Unclear & B - Unclear \\
\hline
\end{tabular}

\section{Lai 2006a}

\begin{tabular}{|c|c|}
\hline Methods & $\begin{array}{l}\text { Parallel design } \\
\text { Method of randomisation: randomised stated, method unclear } \\
\text { Method of concealment: unclear } \\
\text { Blinding: unclear } \\
\text { Analysis: unclear }\end{array}$ \\
\hline Participants & $\begin{array}{l}\text { Location: China } \\
\text { Setting: inpatients } \\
\text { Treatment: } 40 \\
\text { Control: } 40 \\
\text { (Total } 54 \% \text { male, mean age } 60 \text { years, SD 14) } \\
\text { Stroke criteria: unclear; diagnosis via CT; time from stroke to randomisation unclear } \\
\text { Depression criteria: HDRS score > } 6 \\
\text { Other entry criteria: none stated } \\
\text { Comparability of treatment groups: unclear }\end{array}$ \\
\hline Interventions & $\begin{array}{l}\text { Treatment: paroxetine } 20 \mathrm{mg} \text { daily } \\
\text { Control: placebo } \\
\text { Duration: treatment continued for } 2 \text { months }\end{array}$ \\
\hline Outcomes & $\begin{array}{l}\text { Depression: differences in mean scores on HDRS at end of treatment, } 50 \% \text { reduction in scores on HDRS } \\
\text { Additional: Scandinavian Stroke Scale } \\
\text { Death } \\
\text { Adverse events (selected data) }\end{array}$ \\
\hline
\end{tabular}


Unable to use: RS, BI, MMSE (data not presented at follow up)

Adverse events data on dizziness, nausea and cephalalgia (data not presented by group)

\begin{tabular}{lll}
\hline Notes & Exclusion criteria: unclear & \\
\hline Risk of bias & & \\
\hline Item & Authors' judgement & Description \\
\hline Allocation concealment? & Unclear & B - Unclear \\
\hline
\end{tabular}

Lincoln 2003

\begin{tabular}{|c|c|}
\hline Methods & $\begin{array}{l}\text { Parallel design } \\
\text { Method of randomisation: computer-generated random number sequence } \\
\text { Method of concealment: opaque consecutively numbered sealed envelopes held by independent researcher } \\
\text { Blinding: single blind } \\
\text { Participants: no } \\
\text { Investigators: yes } \\
\text { Outcome assessors: yes } \\
\text { Analysis: per protocol: death ( } 2 \text { control), withdrew consent ( } 1 \text { control, } 1 \text { attention control, } 1 \text { treatment), } \\
\text { all excluded from analysis }\end{array}$ \\
\hline Participants & $\begin{array}{l}\text { Location: UK } \\
\text { Setting: outpatients } \\
\text { Treatment: } 39 \text { ( } 51 \% \text { male, mean age } 67 \text { years, SD 13) } \\
\text { Attention control`: } 41 \text { (51\% male, mean age } 66 \text { years, SD 13) } \\
\text { Control}^{\wedge}: 41 \text { ( } 51 \% \text { male, mean age } 65 \text { years, SD 15) } \\
\text { Stroke criteria: all subtypes; diagnosis via clinical signs and symptoms and CT (percentage not reported); } \\
\text { stroke } 1 \text { to } 6 \text { months prior to randomisation } \\
\text { Depression criteria: psychiatric interview (SCAN), BDI score > 10, WDI score > } 18 \\
\text { Other entry criteria: none stated } \\
\text { Comparability of treatment groups: significantly more participants with an ICD-10 diagnosis of depression } \\
\text { in the treatment group }\end{array}$ \\
\hline Interventions & $\begin{array}{l}\text { Treatment: cognitive behavioural therapy, including modification of unhelpful thoughts and beliefs }(10 \mathrm{x} \\
1 \text { hour sessions over } 13 \text { weeks) } \\
\text { Attention control: no formal therapeutic intervention; conversation focused on day-to-day occurrences } \\
\text { and discussion regarding the physical effects of stroke and life changes ( } 10 \mathrm{x} 1 \text { hour visits over } 13 \text { weeks) } \\
\text { Control: standard care (no contact) } \\
\text { Delivered by: community psychiatric nurse }\end{array}$ \\
\hline Outcomes & $\begin{array}{l}\text { Depression: change in scores from baseline to end of treatment and end of follow up on BDI, WDI, GHQ } \\
28^{*} \\
\text { Additional: Leaving the study early } \\
\text { Death } \\
\text { Extended ADL } \\
\text { Unable to use: adverse events (data not presented) }\end{array}$ \\
\hline
\end{tabular}


Lincoln 2003 (Continued)

London Handicap Scale (no mean or SD presented)

\begin{tabular}{ll}
\hline Notes & $\begin{array}{l}\text { Exclusion criteria: blindness, deafness, participant did not speak English, dementia documented in medical } \\
\text { records, treated for depression in previous } 5 \text { years, lived outside specified locality, participant could not } \\
\text { complete questionnaire unaided } \\
\text { Additional unpublished data provided by author }\end{array}$ \\
\hline
\end{tabular}

Risk of bias

\begin{tabular}{l|ll}
\hline Item & Authors' judgement & Description \\
\hline Allocation concealment? & Yes & A - Adequate \\
\hline
\end{tabular}

\section{Lipsey 1984}

\begin{tabular}{|c|c|}
\hline Methods & $\begin{array}{l}\text { Parallel design } \\
\text { Method of randomisation: random number table } \\
\text { Method of concealment: unclear } \\
\text { Blinding: double blind } \\
\text { Participants: yes } \\
\text { Families: yes } \\
\text { Clinical examiners: yes } \\
\text { Nursing staff: yes } \\
\text { Analysis: per protocol: withdrawn due to AE ( } 3 \text { treatment, } 1 \text { control), withdrew consent ( } 1 \text { control), all } \\
\text { excluded from analysis; After at least one week of treatment: withdrew due to AE ( } 3 \text { treatment, } 1 \text { control), } \\
\text { death ( } 2 \text { control), lost to follow-up ( } 2 \text { control), included in analyses using last observation carried forward }\end{array}$ \\
\hline Participants & $\begin{array}{l}\text { Location: USA } \\
\text { Setting: mixed } \\
\text { Treatment: } 17 \text { ( } 64 \% \text { male, mean age } 62 \text { years, SD 9) } \\
\text { Control: } 22 \text { ( } 65 \% \text { male, mean age } 60 \text { years, SD 12) } \\
\text { Stroke criteria: ischaemic stroke and primary intracerebral haemorrhage; diagnosis via clinical signs and } \\
\text { CT (100\%); stroke on average } 262+/-437 \text { days (treatment group) and } 128+/-190 \text { days (control group) } \\
\text { prior to randomisation } \\
\text { Depression criteria: psychiatric interview (PSE, DSM-III) } \\
\text { Other entry criteria: included outpatients who requested treatment for poststroke depressive disorder } \\
\text { Comparability of treatment groups: balanced }\end{array}$ \\
\hline Interventions & $\begin{array}{l}\text { Treatment: nortriptyline } 20 \text { to } 100 \mathrm{mg} \text { daily; } 2 \text { treatment regimens combined; dose escalation over treat- } \\
\text { ment period to } 100 \mathrm{mg} \\
\text { Control: matched placebo } \\
\text { Duration: treatment continued for } 4 \text { to } 6 \text { weeks }\end{array}$ \\
\hline Outcomes & $\begin{array}{l}\text { Depression: change in scores from baseline to end of treatment on HDRS and ZDS*^, } \dagger \\
\text { Proportion no longer meeting entry criteria (DSM-III) } \\
\text { Additional: Leaving the study early } \\
\text { Death } \\
\text { Adverse events }\end{array}$ \\
\hline
\end{tabular}




\section{Lipsey 1984 (Continued)}

Unable to use: PSE (modified by authors), MMSE, John Hopkins Functioning Inventory, Social Ties Checklist (data not presented)

Notes

Exclusion criteria: current treatment for depression, severe comprehension deficit, medical contraindication to nortriptyline

Risk of bias

\begin{tabular}{lll}
\hline Item & Authors' judgement & Description \\
\hline Allocation concealment? & Unclear & B - Unclear \\
\hline
\end{tabular}

\section{Murray 2002}

\begin{tabular}{|c|c|}
\hline Methods & $\begin{array}{l}\text { Parallel design } \\
\text { Method of randomisation: block } \\
\text { Method of concealment: centralised } \\
\text { Blinding: double blind } \\
\text { Participants: yes } \\
\text { Relatives: yes } \\
\text { Clinical examiners: yes } \\
\text { Nursing staff: yes } \\
\text { Analysis: ITT (last observation carried forward) and per protocol: death ( } 2 \text { control), no efficacy (16 } \\
\text { treatment, } 22 \text { control), withdrawn due to AE ( } 8 \text { treatment, } 5 \text { control), withdrew consent (1 control), all } \\
\text { excluded from analysis }\end{array}$ \\
\hline Participants & $\begin{array}{l}\text { Location: Sweden } \\
\text { Setting: mixed } \\
\text { Treatment: } 62 \text { ( } 52 \% \text { male, mean age } 71 \text { years, SD 10) } \\
\text { Control: } 61 \text { ( } 44 \% \text { male, mean age } 71 \text { years, SD 10) } \\
\text { Stroke criteria: all subtypes, diagnosis via clinical signs and CT }(100 \%) \text {; stroke } 3 \text { to } 367 \text { days prior to } \\
\text { randomisation (average time } 128 \text { days) } \\
\text { Depression criteria: psychiatric interview (DSM-IV, major and minor) and MADRS >9 } \\
\text { Other entry criteria: > } 17 \text { years of age, stroke within previous } 12 \text { months } \\
\text { Comparability of treatment groups: significant trend towards more left hemisphere lesion strokes in } \\
\text { treatment group }\end{array}$ \\
\hline Interventions & $\begin{array}{l}\text { Treatment: sertraline } 50 \mathrm{mg} \text { daily; possible dose escalation to } 100 \mathrm{mg} \text { after } 4 \text { weeks } \\
\text { Control: matched placebo } \\
\text { Duration: treatment continued for } 26 \text { weeks }\end{array}$ \\
\hline Outcomes & $\begin{array}{l}\text { Depression: change in scores from baseline to end of treatment on MADRS } \\
\text { Additional: Leaving the study early } \\
\text { Death } \\
\text { Unable to use: Scandinavian Stroke Scale, BI, Stroke Unit Mental Status, Examination social performance, } \\
\text { treatment costs, mortality, relative's situation, neuropsychological performance, neurological recovery (data } \\
\text { not presented) } \\
\text { Adverse events (selected data presented) }\end{array}$ \\
\hline
\end{tabular}


Murray 2002 (Continued)

Exclusion criteria: under 18 years of age, severely impaired communication, apparent difficulties in adher-
ing to study protocol, acute myocardial infarction, other psychiatric illness other than depression, signifi-
cant risk of suicide, antidepressants during the month before randomisation, current use of psychotropic
medication or opiate analgesic drugs
Participants with less than $20 \%$ reduction in MADRS score at 6 weeks were excluded

Risk of bias

\begin{tabular}{l|ll}
\hline Item & Authors' judgement & Description \\
\hline Allocation concealment? & Yes & A - Adequate \\
\hline
\end{tabular}

\section{Ohtomo 1991}

\begin{tabular}{|c|c|c|}
\hline Methods & \multicolumn{2}{|c|}{$\begin{array}{l}\text { Parallel design } \\
\text { Method of randomisation: randomised stated, method unclear } \\
\text { Method of concealment: unclear } \\
\text { Blinding: double blind reported, those blinded not stated } \\
\text { Analysis: unclear }\end{array}$} \\
\hline Participants & \multicolumn{2}{|c|}{$\begin{array}{l}\text { Location: Japan } \\
\text { Setting: unclear } \\
\text { Treatment: } 150 \text { (details unclear) } \\
\text { Control: } 135 \text { (details unclear) } \\
\text { Stroke criteria: ischaemic stroke; method of diagnosis unclear; time from stroke to randomisation unclear } \\
\text { Depression criteria: based on physician's impression, no scale was used for evaluation } \\
\text { Other entry criteria: none stated } \\
\text { Comparability of treatment groups: unclear }\end{array}$} \\
\hline Interventions & \multicolumn{2}{|c|}{$\begin{array}{l}\text { Treatment: aniracetam } 600 \mathrm{mg} \text { twice daily } \\
\text { Control: matched placebo } \\
\text { Duration: treatment continued for } 12 \text { weeks }\end{array}$} \\
\hline Outcomes & \multicolumn{2}{|c|}{$\begin{array}{l}\text { Depression: physician assessment of change in depression from baseline to end of treatment } \\
\text { Additional: physician assessment of change in anxiety } \\
\text { Unable to use: Leaving the study early (data not presented) } \\
\text { Death (data not presented) } \\
\text { Adverse events (data not presented) }\end{array}$} \\
\hline Notes & \multicolumn{2}{|c|}{ Exclusion criteria: unclear } \\
\hline \multicolumn{3}{|l|}{ Risk of bias } \\
\hline Item & Authors' judgement & Description \\
\hline Allocation concealment? & Unclear & B - Unclear \\
\hline
\end{tabular}


Ponzio 2001

\begin{tabular}{|c|c|}
\hline Methods & $\begin{array}{l}\text { Parallel design } \\
\text { Method of randomisation: randomised stated, method unclear } \\
\text { Method of concealment: unclear } \\
\text { Blinding: double blind reported, those blinded not stated } \\
\text { Analysis: ITT }\end{array}$ \\
\hline Participants & $\begin{array}{l}\text { Location: Italy } \\
\text { Setting: outpatient } \\
\text { Treatment: } 112(54 \% \text { male, mean age } 64 \text { years, SD 11) } \\
\text { Control: } 117 \text { ( } 55 \% \text { male, mean age } 66 \text { years, SD 11) } \\
\text { Stroke criteria: unclear; method of diagnosis unclear; time from stroke to randomisation unclear } \\
\text { Depression criteria: MADRS > } 18 \\
\text { Other entry criteria: } 18 \text { to } 85 \text { years of age, MMSE score }>23 \\
\text { Comparability of treatment groups: balanced }\end{array}$ \\
\hline Interventions & $\begin{array}{l}\text { Treatment: paroxetine } 20 \text { to } 40 \mathrm{mg} \text { daily } \\
\text { Control: matched placebo } \\
\text { Duration: treatment continued for } 8 \text { weeks }\end{array}$ \\
\hline Outcomes & $\begin{array}{l}\text { Depression: change in scores from baseline to end of treatment on MADRS, CGI } \\
\text { Additional: Proportion scoring }<7 \text { on MADRS and responders on CGI } \\
\text { Change in Rankin and BI scores from baseline to end of treatment } \\
\text { Adverse events }\end{array}$ \\
\hline Notes & $\begin{array}{l}\text { Exclusion criteria: concurrent predominant psychiatric disorders, psychotropic pharmacotherapy, sub- } \\
\text { stance abuse/dependence, participation in other clinical trials, suicide risk, concomitant medication, in- } \\
\text { tolerance to paroxetine }\end{array}$ \\
\hline
\end{tabular}

\section{Risk of bias}

\begin{tabular}{l|ll}
\hline Item & Authors' judgement & Description \\
\hline Allocation concealment? & Unclear & B - Unclear \\
\hline
\end{tabular}

\section{Rampello 2005}

\begin{tabular}{ll}
\hline Methods & Parallel design \\
& Method of randomisation: computer generated code number \\
Method of concealment: code disclosed on box. \\
Blinding: double blind \\
Participants: yes \\
Investigators: yes (had potential for being unblinded) \\
Outcome assessor: no \\
Analysis: unclear; no-one withdrew from the study \\
\hline Participants & Location: Italy \\
& Setting: outpatient \\
& Treatment: 16 (44\% male, mean age 78 years, SD 4) \\
& Control: 15 (46\% male, mean age 77 years, SD 4)
\end{tabular}




\begin{tabular}{ll} 
& $\begin{array}{l}\text { Stroke criteria: single ischaemic or hemorrhagic stroke; diagnosis via CT and MRI; stroke less than } 12 \\
\text { months prior to randomisation } \\
\text { Depresion criteria: psychiatric interview, HDRS > 20, BDI > 15 } \\
\text { Other entry criteria: presence of major or minor depression, presence of retarded depression, lack of } \\
\text { treatment with antidepressants } 2 \text { weeks prior to randomisation, absence of treatment with neuroleptic } \\
\text { drugs during } 3 \text { months before enrolment, informed consent } \\
\text { Comparability of treatment groups: balanced }\end{array}$ \\
\hline Interventions & $\begin{array}{l}\text { Treatment: reboxetine } 4 \text { mg twice daily } \\
\text { Control: matched placebo } \\
\text { Duration: treatment continued for } 16 \text { weeks }\end{array}$ \\
\hline Outcomes & $\begin{array}{l}\text { Depression: change in scores from baseline to end of treatment on HDRS* and BDI* } \\
\text { Additional: Adverse events } \\
\text { Unable to use: adverse event (data presented in a suitable format for this review) }\end{array}$ \\
\hline Notes & $\begin{array}{l}\text { Exclusion criteria: previous degenerative or expansive neurologic disease, tumours, multiple sclerosis, } \\
\text { amyotrophic sclerosis, hydrocephalus, SAH, Binswanger's disease, history of psychiatric illness (other than } \\
\text { depression), severe aphasia, severe cognitive deficit, chronic alcoholism }\end{array}$ \\
\hline Risk of bias & \begin{tabular}{l} 
Authors' judgement \\
\hline Item
\end{tabular} \\
\hline No
\end{tabular}

\section{Reding 1986}

\begin{tabular}{|c|c|}
\hline Methods & $\begin{array}{l}\text { Parallel design } \\
\text { Method of randomisation: random number table } \\
\text { Method of concealment: unclear } \\
\text { Blinding: double blind } \\
\text { Participants: yes } \\
\text { Treating physician: yes } \\
\text { Analysis: ITT (no drop-outs apparent) }\end{array}$ \\
\hline Participants & $\begin{array}{l}\text { Location: USA } \\
\text { Setting: inpatients } \\
\text { Treatment: } 11 \text { ( } 66 \% \text { male, mean age } 68 \text { years, SE } 2) \\
\text { Control: } 6 \text { ( } 73 \% \text { male, mean age } 68 \text { years, SE } 3) \\
\text { Stroke criteria: all subtypes; diagnosis via clinical signs and CT (\% not reported); stroke on average } 45+/ \\
\text { - } 5 \text { days (treatment group) and } 48+/-13 \text { days (control group) prior to randomisation } \\
\text { Depression criteria: psychiatric interview (DSM-III, major and minor) } \\
\text { Other entry criteria: none stated } \\
\text { Comparability of treatment groups: unclear }\end{array}$ \\
\hline
\end{tabular}




\section{Reding 1986 (Continued)}

\begin{tabular}{|c|c|c|}
\hline Interventions & \multicolumn{2}{|c|}{$\begin{array}{l}\text { Treatment: trazodone- } \mathrm{HCl} 50 \mathrm{mg} \text { daily; dose escalation every } 3 \text { days to target dose of } 200 \mathrm{mg} \\
\text { Control: matched placebo } \\
\text { Duration: treatment continued for } 32+/-6 \text { days (treatment group) and } 24+/-4 \text { days (control group) }\end{array}$} \\
\hline Outcomes & \multicolumn{2}{|c|}{$\begin{array}{l}\text { Depression: clinical diagnosis of depression } \\
\text { Additional: BI } \\
\text { Unable to use: clinical diagnosis of depression, ZDS, death (data not presented) } \\
\text { Leaving the study early } \\
\text { Adverse events (data not presented by group) }\end{array}$} \\
\hline Notes & \multicolumn{2}{|c|}{ Exclusion criteria: myocardial infarction within previous month, antiarrhythmic medication } \\
\hline \multicolumn{3}{|l|}{ Risk of bias } \\
\hline Item & Authors' judgement & Description \\
\hline Allocation concealment? & Unclear & B - Unclear \\
\hline
\end{tabular}

\section{Towle 1989}

\begin{tabular}{|c|c|}
\hline Methods & $\begin{array}{l}\text { Parallel design } \\
\text { Method of randomisation: random number tables } \\
\text { Method of concealment: sealed envelopes held by secretary } \\
\text { Blinding: single blind } \\
\text { Participants: no } \\
\text { Investigators: no } \\
\text { Outcome assessor: yes } \\
\text { Analysis: per protocol: withdrew consent ( } 1 \text { control), excluded from analysis }\end{array}$ \\
\hline Participants & $\begin{array}{l}\text { Location: UK } \\
\text { Setting: outpatients } \\
\text { Treatment: } 21 \text { ( } 43 \% \text { male, mean age } 70 \text { years, SD 9) } \\
\text { Control: } 23 \text { ( } 30 \% \text { male, mean age } 69 \text { years, SD 7) } \\
\text { Stroke criteria: all subtypes; diagnosis via clinical signs; stroke on average } 25+/-7 \text { months (treatment } \\
\text { group) and } 25+/-6 \text { months (control group) prior to randomisation } \\
\text { Depression criteria: WDI score > } 17 \text { or GHQ-28 score }>9 \\
\text { Other entry criteria: able to complete questionnaires unaided } \\
\text { Comparability of treatment groups: demographically balanced, treatment group reported more social } \\
\text { dysfunction on GHQ-28 }\end{array}$ \\
\hline Interventions & $\begin{array}{l}\text { Treatment: pragmatic approach dealing with problems identified by social worker and the patients; in- } \\
\text { cluded counselling the patient and caregiver, giving opportunity to reflect upon their situation and express } \\
\text { their feelings (duration: } 2 \text { to } 11 \text { visits over } 16 \text { weeks, mean number visits } 6.8+/-2.8 \text { ) } \\
\text { Control: custom designed information booklet, } 1 \text { visit, no ongoing visits } \\
\text { Delivered by: social worker }\end{array}$ \\
\hline
\end{tabular}


Towle 1989 (Continued)

\begin{tabular}{|c|c|c|}
\hline Outcomes & \multicolumn{2}{|c|}{$\begin{array}{l}\text { Depression: change in scores from baseline to end of treatment on WDI, GHQ-28, proportion no longer } \\
\text { meeting entry criteria } \\
\text { Additional: Leaving the study early } \\
\text { Unable to use: WDI, GHQ-28, Extended ADL, FAI, services questionnaire, Life Satisfaction Index, } \\
\text { Nottingham Health Profile (data presented as median and range) } \\
\text { Death } \\
\text { Adverse events (data not presented) }\end{array}$} \\
\hline Notes & \multicolumn{2}{|c|}{ Exclusion criteria: stroke $<1$ year prior to randomisation, residence in hospital or residential care } \\
\hline \multicolumn{3}{|l|}{ Risk of bias } \\
\hline Item & Authors' judgement & Description \\
\hline Allocation concealment? & Yes & A - Adequate \\
\hline
\end{tabular}

Watkins 2007

\begin{tabular}{|c|c|}
\hline Methods & $\begin{array}{l}\text { Parallel design } \\
\text { Method of randomisation: computer package minimizing for age, sex, baseline BI score, stay on acute } \\
\text { stroke unit; therapist assignment by opaque envelope } \\
\text { Method of concealment: computer program for initial randomisation, opaque envelope for therapist } \\
\text { Blinding: open trial } \\
\text { Analysis: ITT (hot deck imputation), death ( } 3 \text { treatment, } 8 \text { control) }\end{array}$ \\
\hline Participants & $\begin{array}{l}\text { Location: UK } \\
\text { Setting: inpatient } \\
\text { Treatment: } 127 \text { ( } 52 \% \text { male, mean age } 68 \text { years, SD 12) } \\
\text { Control: } 127 \text { ( } 53 \% \text { male, mean age } 68 \text { years, SD 12) } \\
\text { Stroke criteria: all subtypes; diagnosis via clinical signs and CT }(100 \%) \text {; stroke } 5 \text { to } 28 \text { days prior to } \\
\text { randomisation } \\
\text { Depression criteria: GHQ score > } 4 \\
\text { Other entry criteria: over } 18 \text { years } \\
\text { Comparability of treatment groups: balanced }\end{array}$ \\
\hline Interventions & $\begin{array}{l}\text { Treatment: motivational interviewing, up to } 4 \text { sessions, } 1 \text { per week, with same therapist } \\
\text { Control: usual care } \\
\text { Delivered by: nurses and non-clinical psychologists }\end{array}$ \\
\hline Outcomes & $\begin{array}{l}\text { Depression: no longer meeting study criteria for depression on GHQ-28, change in scores from baseline } \\
\text { to end of treatment on GHQ-28 } \\
\text { Additional: Yale, BI, Stroke Expectations Questionnaire }\end{array}$ \\
\hline Notes & $\begin{array}{l}\text { Exclusion criteria: severe cognitive and communication problems, moving out of the area after discharge, } \\
\text { already receiving psychiatric or clinical psychology intervention } \\
\text { Additional unpublished data provided by authors }\end{array}$ \\
\hline
\end{tabular}


Watkins 2007 (Continued)

\section{Risk of bias}

\begin{tabular}{l|ll}
\hline Item & Authors' judgement & Description \\
\hline Allocation concealment? & Yes & A - Adequate \\
\hline
\end{tabular}

\section{Wiart 2000}

Methods

Parallel design

Method of randomisation: randomised stated, method unclear

Method of concealment: unclear

Blinding: double blind reported, those blinded not stated

Analysis: ITT (last observation carried forward), withdrawn due to AE (1 treatment), protocol violation (1 treatment)

\begin{tabular}{|c|c|}
\hline Participants & $\begin{array}{l}\text { Location: France } \\
\text { Setting: unclear } \\
\text { Treatment: } 16 \text { ( } 56 \% \text { male, mean age } 66 \text { years, SD 7) } \\
\text { Control: } 15 \text { ( } 40 \% \text { male, mean age } 69 \text { years, SD } 12) \\
\text { Stroke criteria: ischaemic stroke and primary intracerebral haemorrhage; diagnosis via clinical signs and } \\
\text { CT ( } 100 \%) \text {; stroke on average } 47+/-22 \text { days (treatment group) and } 48+/-20 \text { days (control group) prior } \\
\text { to randomisation } \\
\text { Depression criteria: psychiatric interview (ICD-10 criteria) and MADRS score }>19 \\
\text { Other entry criteria: all antidepressant or neuroleptic drugs stopped } 10 \text { days prior to enrolment } \\
\text { Comparability of treatment groups: balanced }\end{array}$ \\
\hline Interventions & $\begin{array}{l}\text { Treatment: fluoxetine } 20 \mathrm{mg} \text { daily } \\
\text { Control: matched placebo } \\
\text { Duration: treatment continued for } 45 \text { days }\end{array}$ \\
\hline Outcomes & $\begin{array}{l}\text { Depression: change in scores from baseline to end of treatment on MADRS, } 50 \% \text { reduction in MADRS } \\
\text { score } \\
\text { Additional: Functional Independence Measure } \\
\text { MMSE } \\
\text { Motoricity Index } \\
\text { Leaving the study early } \\
\text { Death } \\
\text { Adverse events }\end{array}$ \\
\hline Notes & $\begin{array}{l}\text { Exclusion criteria: severe psychiatric problems which required hospitalisation, severe cognitive impairment, } \\
\text { chronic alcoholism, chronic associated handicapping pathology, contraindication to fluoxetine }\end{array}$ \\
\hline
\end{tabular}

Risk of bias

\begin{tabular}{l|l|l}
\hline Item & Authors' judgement & Description \\
\hline Allocation concealment? & Unclear & B - Unclear \\
\hline
\end{tabular}




\begin{tabular}{|c|c|}
\hline Methods & $\begin{array}{l}\text { Parallel design } \\
\text { Method of randomisation: randomised stated, method unclear } \\
\text { Method of concealment: unclear } \\
\text { Blinding: unclear } \\
\text { Analysis: unclear, withdrawn due to AE (4 treatment, } 7 \text { control) }\end{array}$ \\
\hline Participants & $\begin{array}{l}\text { Location: China } \\
\text { Setting: outpatient } \\
\text { Treatment: } 64 \text { (63\% male, mean age } 64 \text { years, SD 3) } \\
\text { Control: } 57 \text { ( } 56 \% \text { male, mean age } 63 \text { years, SD 5) } \\
\text { Stroke criteria: ischaemic and haemorrhagic stroke; diagnosis unclear; stroke range } 1.5 \text { to } 6 \text { months prior } \\
\text { to randomisation } \\
\text { Depression criteria: HDRS score }>7 \\
\text { Other entry criteria: unclear } \\
\text { Comparability of treatment groups: balanced }\end{array}$ \\
\hline Interventions & $\begin{array}{l}\text { Treatment: paroxetine } 20 \mathrm{mg} \text { daily } \\
\text { Control: matched placebo } \\
\text { Duration: treatment continued for } 4 \text { months }\end{array}$ \\
\hline Outcomes & $\begin{array}{l}\text { Depression: } 50 \% \text { reduction in scores from baseline to end of treatment on HDRS } \\
\text { Additional: cured: defined as scoring }<7 \text { in } 2 \text { consecutive weeks (unable to use as timing of these } 2 \text { weeks } \\
\text { not stated) }\end{array}$ \\
\hline Notes & Exclusion criteria: unclear \\
\hline \multicolumn{2}{|l|}{ Risk of bias } \\
\hline Item & Authors' judgement \\
\hline Allocation concealment? & B - Unclear \\
\hline
\end{tabular}

Zhao 2004

$\begin{array}{ll}\text { Methods } & \text { Parallel design } \\ & \text { Method of randomisation: randomised stated, method unclear, but stratified by age, sex and stroke subtype } \\ & \text { Method of concealment: unclear } \\ \text { Blinding: unclear } \\ \text { Analysis: unclear }\end{array}$


Zhao 2004 (Continued)

\begin{tabular}{|c|c|c|}
\hline Interventions & \multicolumn{2}{|c|}{$\begin{array}{l}\text { Treatment: psycho-education, daily, less than } 30 \text { minutes } \\
\text { Control: usual care } \\
\text { Duration: treatment continued for } 4 \text { weeks } \\
\text { Delivered by: special personnel }\end{array}$} \\
\hline Outcomes & \multicolumn{2}{|c|}{ Depression: reduction in scores from baseline to end of treatment on HDRS* } \\
\hline Notes & \multicolumn{2}{|c|}{ Exclusion criteria: unclear } \\
\hline \multicolumn{3}{|l|}{ Risk of bias } \\
\hline Item & Authors' judgement & Description \\
\hline Allocation concealment? & Unclear & B - Unclear \\
\hline
\end{tabular}

*: Change scores calculated by review authors from available data

** Results for control group halved

$\wedge$ : Results for attention-control and control group pooled

$\wedge^{\wedge}$ : Standard deviation of mean scores calculated from standard errors by review authors

$\dagger$ : Mean and standard deviation scores extrapolated from figures in paper

ADL: activities of daily living

AE: adverse event(s)

BDI: Beck Depression Inventory

CSS: Chinese Stroke Scale

CT: computed tomography

BI: Barthel Index

DSM: Diagnostic Scientific Manual

FAI: Frenchay Activities Index

FAST: Frenchay Aphasia Screening Test

GDS: Geriatric Depression Scale

GHQ: General Health Questionnaire

HARS: Hamilton Anxiety Rating Scale

HDRS: Hamilton Depression Rating Scale

HRQoL: Health Related Quality of Life

ICD: International Classification of Diseases

ITT: intention to treat

MADRS: Montgomery Asberg Depression Rating Scale

MMSE: Mini-Mental State Examination

PSE: Present State Examination

RS: Rankin Scale

SD: standard deviation

SE: standard error

WDI: Wakefield Depression Inventory

ZDS: Zung Depression Scale 
Characteristics of excluded studies [ordered by study ID]

\begin{tabular}{|c|c|}
\hline Study & Reason for exclusion \\
\hline Agnoli 1985 & $\begin{array}{l}\text { Allocation: randomised } \\
\text { Participants: chronic cerebrovascular disease: unable to isolate stroke patients }\end{array}$ \\
\hline Aizawa 1986 & $\begin{array}{l}\text { Allocation: randomised } \\
\text { Participants: cerebrovascular disorders } \\
\text { Interventions: no placebo comparison }\end{array}$ \\
\hline Balunov 1990 & $\begin{array}{l}\text { Allocation: randomised } \\
\text { Participants: poststroke depression } \\
\text { Interventions: no placebo comparison }\end{array}$ \\
\hline Bao 2001 & $\begin{array}{l}\text { Allocation: nnclear } \\
\text { Participants: post stroke } \\
\text { Interventions: some patients in the intervention group received antidepressants, no one in the control group } \\
\text { did }\end{array}$ \\
\hline Battaglia 1999 & $\begin{array}{l}\text { Allocation: randomised } \\
\text { Participants: post stroke } \\
\text { Interventions: Nno placebo comparison }\end{array}$ \\
\hline Battaglia 2001 & $\begin{array}{l}\text { Allocation: randomised } \\
\text { Participants: post stroke } \\
\text { Interventions: no placebo comparison }\end{array}$ \\
\hline Bautz-Holter 2002 & $\begin{array}{l}\text { Allocation: randomised } \\
\text { Participants: post stroke } \\
\text { Interventions: early supported discharge, did not meet review criteria, not structured or timetabled as a talking } \\
\text { therapy }\end{array}$ \\
\hline Berrol 1997 & $\begin{array}{l}\text { Allocation: random } \\
\text { Participants: post stroke } \\
\text { Intervention: dance/movement therapy, did not meet review criteria }\end{array}$ \\
\hline Casella 1960 & $\begin{array}{l}\text { Allocation: quasi randomised } \\
\text { Participants: hemiplegia, unable to isolate stroke } \\
\text { Interventions: iproniazid } \\
\text { Outcome: depression not primary endpoint }\end{array}$ \\
\hline Chen 2001 & $\begin{array}{l}\text { Allocation: randomised } \\
\text { Participants: post stroke } \\
\text { Interventions: fluoxetine, no placebo control (routine care) }\end{array}$ \\
\hline Chen 2002 & $\begin{array}{l}\text { Allocation: randomised } \\
\text { Participants: post stroke } \\
\text { Interventions: fluoxetine, doxepine, vitamin B6, no placebo control }\end{array}$ \\
\hline
\end{tabular}




\begin{tabular}{ll} 
Chen 2005 & $\begin{array}{l}\text { Allocation: randomised } \\
\text { Participants: post stroke } \\
\text { Interventions: citalopram or fluoxetine, no placebo control (activating blood circulation and rehabilitation) }\end{array}$ \\
\hline Chen 2005a & $\begin{array}{l}\text { Allocation: randomised } \\
\text { Participants: post stroke } \\
\text { Interventions: repetitive transcranial magnetic stimulation not meeting review criteria }\end{array}$ \\
\hline Cheng 2003 & $\begin{array}{l}\text { Allocation: randomised } \\
\text { Participants: post stroke } \\
\text { Interventions: fluoxetine, no placebo control arm (routine care) }\end{array}$ \\
\hline Cheng 2003a & $\begin{array}{l}\text { Allocation: unclear } \\
\text { Participants: post stroke } \\
\text { Interventions: fluoxetine, no placebo control (routine care) }\end{array}$ \\
\hline
\end{tabular}

\begin{tabular}{ll}
\hline Choi-Kwon 2006 & $\begin{array}{l}\text { Allocation: randomised } \\
\text { Participants: post stroke } \\
\text { Interventions: fluoxetine, treatment trial for depression, emotionalism and anger } \\
\text { Outcome: data not available in depressed and not depressed with proportions, mean scores and standard } \\
\text { deviations }\end{array}$ \\
\hline Christie 1984 & $\begin{array}{l}\text { Allocation: randomised } \\
\text { Participants: post stroke } \\
\text { Interventions: social work, did not meet review criteria, not structured or timetabled as a talking therapy }\end{array}$ \\
\hline Corr 1995 & $\begin{array}{l}\text { Allocation: randomised } \\
\text { Participants: post stroke } \\
\text { Interventions: rehabilitation, did not meet review criteria, not structured or timetabled as a talking therapy }\end{array}$ \\
\hline
\end{tabular}

\begin{tabular}{l} 
Corr $2004 \quad \begin{array}{l}\text { Allocation: randomised } \\
\text { Participants: post stroke } \\
\text { Interventions: cross-over study design. No drug or psychological intervention involved }\end{array}$ \\
\hline
\end{tabular}

\begin{tabular}{ll} 
Cui 2001 & $\begin{array}{l}\text { Allocation: not randomised } \\
\text { Participants: post stroke } \\
\text { Intervention: no placebo comparison }\end{array}$ \\
\hline Cullum 2007 & $\begin{array}{l}\text { Allocation: randomised } \\
\text { Participants: older medical patients including stroke } \\
\text { Intervention: liaison psychiatric nurse + care plan including psychotherapy and/or antidepressents, not meet } \\
\text { review criteria }\end{array}$ \\
\hline
\end{tabular}

Davis 1997
Allocation: randomised
Participants: post stroke
Interventions: life review therapy
Outcome: therapy did not develop social problem solving skills or adjustment to stroke, did not meet review
criteria


(Continued)

\begin{tabular}{ll} 
Dennis 1997 & $\begin{array}{l}\text { Allocation: randomised } \\
\text { Participants: post stroke } \\
\text { Interventions: stroke family careworker, did not meet review criteria, not structured or timetabled as a talking } \\
\text { therapy }\end{array}$ \\
\hline Dennis 2000 & $\begin{array}{l}\text { Allocation: randomised } \\
\text { Participants: post stroke } \\
\text { Interventions: stroke family careworker, did not meet review criteria, not structured or timetabled as a talking } \\
\text { therapy }\end{array}$ \\
\hline Desrosiers 2007 & $\begin{array}{l}\text { Allocation: unclear } \\
\text { Participants: post stroke } \\
\text { Intervention: leisure education programme, did not meet review criteria }\end{array}$ \\
\hline Dong 2007 & $\begin{array}{l}\text { Allocation: randomised } \\
\text { Participants: post stroke } \\
\text { Intervention: electroacupuncture, western medicine, did not meet review criteria }\end{array}$ \\
\hline Downes 1995 & $\begin{array}{l}\text { Allocation: tandomised } \\
\text { Participants: post stroke } \\
\text { Interventions: Egan's problem solving therapy } \\
\text { Outcome: data not currently available }\end{array}$ \\
\hline
\end{tabular}

Drummond 1995 Allocation: randomised

Participants: post stroke

Interventions: leisure rehabilitation, did not meet review criteria, not structured or timetabled as a talking therapy

Du $2005 \quad$ Allocation: randomised

Participants: post stroke

Interventions: repetitive transcranial magnetic stimulation not meeting review criteria

Evans 1997 Allocation: randomised
Participants: acute geriatric medical inpatients with depression, unable to isolate any chronic stroke patients
No acute stroke patients included in sample

$\begin{array}{ll}\text { Feng } 2004 & \text { Allocation: random } \\ & \text { Participants: post stroke } \\ & \text { Intervention: fluoxetine, jieyu huoxue decoction, no placebo control }\end{array}$

\begin{tabular}{ll}
\hline Feng 2005 & $\begin{array}{l}\text { Allocation: randomised } \\
\text { Participants: post stroke } \\
\text { Intervention: psychotherapy intervenion inlcudes exercise therapy which wasn't included in the control group }\end{array}$ \\
\hline Fengqi 2003 & $\begin{array}{l}\text { Allocation: randomised } \\
\text { Participants: post stroke } \\
\text { Interventions: yukangning - traditional Chinese medicine, no placebo comparison }\end{array}$
\end{tabular}




\begin{tabular}{ll} 
FX Project 1976 & $\begin{array}{l}\text { Allocation: randomised } \\
\text { Participants: cerebrovascular diseases, those with stroke unable to be isolated }\end{array}$ \\
\hline Gekht 2002 & $\begin{array}{l}\text { Allocation: randomised } \\
\text { Participants: post stroke } \\
\text { Interventions: no placebo comparison }\end{array}$ \\
\hline Gekht 2003 & $\begin{array}{l}\text { Allocation: not randomised, 'divided' } \\
\text { Participants: post stroke } \\
\text { Interventions: no placebo comparison }\end{array}$ \\
\hline Goh 2001 & $\begin{array}{l}\text { Allocation: randomised } \\
\text { Participants: post stroke } \\
\text { Interventions: music therapy, did not meet review criteria, not structured or timetabled as a talking therapy }\end{array}$ \\
\hline Gonzalez-T 1995 & $\begin{array}{l}\text { Allocation: quasi randomised } \\
\text { Participants: depressed post stroke } \\
\text { Interventions: no placebo comparison }\end{array}$ \\
\hline
\end{tabular}

$\begin{array}{ll}\text { Graffagnino } 2003 & \text { Allocation: randomised } \\ & \text { Participants: post stroke } \\ & \text { Interventions: sertraline with matched placebo } \\ & \text { Outcomes: data not currently available }\end{array}$

Green $2002 \quad$ Allocation: randomised

Participants: post stroke

Interventions: physiotherapy, did not meet review criteria, not structured or timetabled as a talking therapy

Guan $2003 \quad$ Allocation: randomised
Participants: post stroke
Interventions: fluoxetine, levodopa, no placebo control

$\begin{array}{ll}\text { Guan } 2004 & \text { Allocation: random } \\ \text { Participants: post stroke } \\ \text { Interventions: patients in the intervention group received fluoxetine, no one in the control group did }\end{array}$

\begin{tabular}{ll}
\hline He 2001 & $\begin{array}{l}\text { Allocation: randomised } \\
\text { Participants: post stroke } \\
\text { Interventions: combined Chinese antidepressants and psychotherapy with no placebo control }\end{array}$ \\
\hline He 2003 & $\begin{array}{l}\text { Allocation: random } \\
\text { Participants: post stroke } \\
\text { Interventions: combined psychotherapy with amitriptyline, no placebo control }\end{array}$ \\
\hline He 2004 & $\begin{array}{l}\text { Allocation: quasi randomised } \\
\text { Participants: post stroke } \\
\text { Interventions: fluoxetine, no placebo control }\end{array}$
\end{tabular}


(Continued)

\begin{tabular}{ll} 
He 2005 & $\begin{array}{l}\text { Allocation: randomised } \\
\text { Participants: post stroke } \\
\text { Interventions: paroxetine and psychotherapy, no placebo control, only a usual care arm }\end{array}$ \\
\hline Hindle 2007 & $\begin{array}{l}\text { Allocation: randomised } \\
\text { Participants: post stroke } \\
\text { Interventions: sertraline } \\
\text { Outcomes: trial not completed }\end{array}$ \\
\hline
\end{tabular}

\begin{tabular}{ll} 
Hogg 1985 & $\begin{array}{l}\text { Allocation: randomised } \\
\text { Participants: post stroke } \\
\text { Interventions: acupressure versus therapeutic touch, no placebo control, intervention not meet review criteria }\end{array}$ \\
\hline Hong 2004 & $\begin{array}{l}\text { Allocation: randomised } \\
\text { Participants: post stroke } \\
\text { Interventions: yuxingchangzhi tang and fluoxetine, no placebo control }\end{array}$ \\
\hline
\end{tabular}

\begin{tabular}{ll} 
House 2005 & Allocation: randomised \\
Participants: post stroke & Intervention: SSRI \\
& Trial not completed due to recruitment problems \\
\hline
\end{tabular}

\begin{tabular}{ll}
\hline Hu 2002 & Allocation: randomised \\
& Participants: post stroke \\
& Intervention: fluoxetine, no placebo control \\
\hline
\end{tabular}

\begin{tabular}{ll}
\hline Hu 2005 & $\begin{array}{l}\text { Allocation: randomised } \\
\text { Participants: post stroke } \\
\text { Interventions: psychotherapy combined with fluoxetine, no placebo control }\end{array}$ \\
\hline Huang 2001 & $\begin{array}{l}\text { Allocation: randomised } \\
\text { Participants: post stroke } \\
\text { Interventions: no placebo comparison }\end{array}$ \\
\hline Huang 2004 & $\begin{array}{l}\text { Allocation: random } \\
\text { Participants: post stroke } \\
\text { Interventions: acupuncture, amitriptyline, no placebo comparison }\end{array}$ \\
\hline Hui 1995 & $\begin{array}{l}\text { Allocation: randomised } \\
\text { Participants: post stroke } \\
\text { Interventions: medical management, did not meet criteria, not structured or timetabled as a talking therapy }\end{array}$ \\
\hline Isenberg 2000 & $\begin{array}{l}\text { Allocation: unclear } \\
\text { Participants: post stroke } \\
\text { Interventions: nefiracetam } \\
\text { Outcomes: dta not currently available }\end{array}$
\end{tabular}




\begin{tabular}{ll}
\hline Ji 2000 & $\begin{array}{l}\text { Allocation: randomised } \\
\text { Participants: post stroke } \\
\text { Interventions: no placebo comparison }\end{array}$ \\
\hline Jia 2005 & $\begin{array}{l}\text { Allocation: random } \\
\text { Participants: post stroke } \\
\text { Interventions: fluoxetine, no placebo control }\end{array}$ \\
\hline
\end{tabular}

\begin{tabular}{ll}
\hline Johnson 2000 & Allocation: randomised \\
& Participants: post stroke \\
& $\begin{array}{l}\text { Interventions: group/class education, did not meet review criteria, not structured or timetabled as a talking } \\
\text { therapy }\end{array}$ \\
\hline
\end{tabular}

\begin{tabular}{ll}
\hline Jongbloed 1991 & Allocation: randomised \\
& Participants: post stroke \\
& $\begin{array}{l}\text { Interventions: occupational leisure therapy, did not meet review criteria, not structured or timetabled as a } \\
\text { talking therapy }\end{array}$ \\
\hline
\end{tabular}

\begin{tabular}{ll}
\hline Jorge 2004 & Allocation: randomised \\
& Participants: post stroke \\
& Interventions: transcranial magnetic stimulation, did not meet review criteria \\
\hline
\end{tabular}

\begin{tabular}{ll}
\hline Joubert 2006 & Allocation: randomised \\
& Participants: post stroke \\
& Interventions: no placebo comparison \\
\hline
\end{tabular}

\begin{tabular}{ll}
\hline Juby 1996 & $\begin{array}{l}\text { Allocation: randomised } \\
\text { Participants: post stroke } \\
\text { Interventions: medical management, did not meet review criteria, not structured or timetabled as a talking } \\
\text { therapy }\end{array}$ \\
\hline Kendall 2007 & $\begin{array}{l}\text { Allocation: randomised } \\
\text { Participants: post stroke } \\
\text { Interventions: primarily education and not delivered by somebody with explicitly stated training and super- } \\
\text { vision in therapies }\end{array}$ \\
\hline
\end{tabular}

\begin{tabular}{ll}
\hline Kwon 2003 & $\begin{array}{l}\text { Allocation: quasi randomised } \\
\text { Participants: post stroke } \\
\text { Interventions: taping/physiological, did not meet review criteria }\end{array}$ \\
\hline Lai 2006b & $\begin{array}{l}\text { Allocation: randomised } \\
\text { Participants: post stroke } \\
\text { Interventions: physical exercise program - did not meet review criteria }\end{array}$ \\
\hline Laska 2005 & $\begin{array}{l}\text { Allocation: randomised } \\
\text { Participants: acute stroke with aphasia } \\
\text { Interventions: moclobemide } \\
\text { Outcome: aphasia }\end{array}$
\end{tabular}


(Continued)

$\begin{array}{ll}\text { Lauritzen } 1994 & \text { Allocation: randomised } \\ & \text { Participants: post stroke } \\ & \text { Interventions: no placebo comparison }\end{array}$

Lee 2005
$\begin{aligned} & \text { Allocation: unclear } \\ & \text { Participants: post stroke } \\ & \text { Interventions: repetitive transcranial magnetic stimulation, does not meet review criteria }\end{aligned}$

$\begin{array}{ll}\text { Lehmann } 2001 & \text { Allocation: randomised } \\ & \text { Participants: post stroke } \\ & \text { Interventions: imipramine, piracetam,versus usual care, no placebo comparison }\end{array}$

$\begin{array}{ll}\text { Leijon } 1989 & \text { Allocation: randomised } \\ \text { Participants: post stroke } \\ \text { Interventions: amitriptyline and carbamazepine } \\ \text { Outcome: pain }\end{array}$

Li $1994 \quad \begin{aligned} & \text { Allocation: randomised } \\ & \text { Participants: post stroke } \\ & \text { Interventions: no placebo comparison }\end{aligned}$

\begin{tabular}{l} 
Li $1999 \quad \begin{array}{l}\text { Allocation: randomised } \\
\text { Participants: post stroke } \\
\text { Interventions: no placebo comparison }\end{array}$ \\
\hline
\end{tabular}

\begin{tabular}{ll} 
Li 2000 & Allocation: randomised \\
& Participants: post stroke \\
& Interventions: no placebo comparison \\
\hline
\end{tabular}

Li $2002 \quad$ Allocation: randomised

Participants: post stroke

Interventions: no placebo comparison (paroxetine versus traditional Chinese medicine)

$\begin{array}{ll}\text { Li } 2004 & \text { Allocation: randomised } \\ \text { Participants: post stroke } \\ \text { Interventions: fluoxetine versus usual care, no placebo comparison }\end{array}$

\begin{tabular}{ll}
\hline Li 2004a & $\begin{array}{l}\text { Allocation: random } \\
\text { Participants: post stroke }\end{array}$ \\
& $\begin{array}{l}\text { Interventions: antidepressant + activities of daily living training + psychotherapy + early rehabilitation, does } \\
\text { not meet review criteria }\end{array}$ \\
\hline Li 2004b & $\begin{array}{l}\text { Allocation: random } \\
\text { Participants: post stroke } \\
\text { Interventions: psychotherapy + antidepressant (unspecified) versus usual care, no placebo comparison }\end{array}$
\end{tabular}




\begin{tabular}{ll}
\hline Li 2004c & $\begin{array}{l}\text { Allocation: random } \\
\text { Participants: post stroke } \\
\text { Interventions: antidepressants (unspecified) versus usual care, no placebo comparison }\end{array}$ \\
\hline Li 2004d & $\begin{array}{l}\text { Allocation: unclear } \\
\text { Participants: post stroke } \\
\text { Interventions: patients in the intervention group received antidepressants, no one in the control group did }\end{array}$ \\
\hline Li 2005 & $\begin{array}{l}\text { Allocation: randomised } \\
\text { Participants: post stroke } \\
\text { Interventions: doxepin hydrochloride no placebo control }\end{array}$ \\
\hline
\end{tabular}

\begin{tabular}{ll}
\hline Liang 2003 & $\begin{array}{l}\text { Allocation: randomised } \\
\text { Participants: post stroke } \\
\text { Interventions: fluoxetine, no placebo comparison }\end{array}$ \\
\hline Liang 2005 & $\begin{array}{l}\text { Allocation: randomised } \\
\text { Participants: post stroke } \\
\text { Interventions: no placebo control }\end{array}$ \\
\hline
\end{tabular}

\begin{tabular}{ll} 
Liborio 2002 & Allocation: randomised \\
& Participants: post stroke \\
& Interventions: no placebo comparison \\
\hline
\end{tabular}

\begin{tabular}{l} 
Lin 2005 \\
Allocation: randomised \\
Participants: post stroke \\
Interventions: psychotherapy and/or antidepressant care, no placebo control \\
\hline
\end{tabular}

$\begin{array}{ll}\text { Lincoln } 1985 & \text { Allocation: randomised } \\ & \text { Participants: post stroke } \\ \text { Interventions: speech therapy, did not meet review criteria, not structured or timetabled as a talking therapy }\end{array}$

\begin{tabular}{ll}
\hline Liu 2003 & Allocation: unclear \\
& Participants: silent stroke (not meet review criteria) \\
& Interventions: antidepressant + psychological intervention (not meet review criteria) \\
\hline
\end{tabular}

\begin{tabular}{l} 
Liu 2003a \\
$\begin{array}{l}\text { Allocation: unclear } \\
\text { Participants: post stroke } \\
\text { Interventions: fastigial nucleus electrical stimulation + antidepressant therapy (not meet review criteria) versus } \\
\text { routine drug (unspecified) versus control, no placebo control group }\end{array}$ \\
\hline
\end{tabular}

\begin{tabular}{ll}
\hline Liu 2006 & $\begin{array}{l}\text { Allocation: randomised } \\
\text { Participants: post stroke } \\
\text { Interventions: yu le shu, fluoxetine, no placebo control }\end{array}$ \\
\hline Liu 2006a & $\begin{array}{l}\text { Allocation: randomised } \\
\text { Participants: post stroke } \\
\text { Interventions: fluoxetine and acup-moxibustion, no placebo comparison }\end{array}$ \\
\hline
\end{tabular}




\begin{tabular}{ll} 
Liu 2006b & $\begin{array}{l}\text { Allocation: randomised } \\
\text { Participants: post stroke } \\
\text { Interventions: citalopram versus amitriptyline, no placebo comaprison }\end{array}$ \\
\hline Lu 2005 & $\begin{array}{l}\text { Allocation: randomised } \\
\text { Participants: diabetic patients post stroke } \\
\text { Interventions: cognitive therapy + electromyographic feedback + medication (not meet criteria) versus usual } \\
\text { care }\end{array}$ \\
\hline Mant 1998 & $\begin{array}{l}\text { Allocation: randomised } \\
\text { Participants: post stroke } \\
\text { Interventions: information pack, did not meet review criteria, not structured or timetabled as a talking therapy }\end{array}$ \\
\hline Mant 2000 & $\begin{array}{l}\text { Allocation: randomised } \\
\text { Participants: post stroke } \\
\text { Interventions: family support, did not meet review criteria, not structured or timetabled as a talking therapy }\end{array}$ \\
\hline Martucci 1986 & $\begin{array}{l}\text { Allocation: randomised } \\
\text { Participants: unable to isolate people with stroke }\end{array}$ \\
\hline Mauri 1988 & $\begin{array}{l}\text { Allocation: randomised } \\
\text { Participants: post stroke } \\
\text { Interventions: mianserin vs placebo } \\
\text { Outcomes: not available in a format appropriate for this review }\end{array}$ \\
\hline
\end{tabular}

\begin{tabular}{ll}
\hline Meara 1998 & Allocation: randomised \\
& Participants: post stroke \\
& Interventions: sertraline with matched placebo for 6 weeks \\
& Outcome: data not currently available \\
\hline
\end{tabular}

$\begin{array}{ll}\text { Meng } 1996 & \text { Allocation: unclear } \\ & \text { Participants: post stroke } \\ & \text { Interventions: mi-an-she-lin versus amitriptyline, no placebo control }\end{array}$

\begin{tabular}{ll}
\hline Miao 2004 & $\begin{array}{l}\text { Allocation: random } \\
\text { Participants: post stroke } \\
\text { Interventions: citalopram versus usual care, no placebo control }\end{array}$ \\
\hline Min 2002 & $\begin{array}{l}\text { Allocation: randomised } \\
\text { Participants: post stroke } \\
\text { Interventions: no placebo control (control group received physcological rehabilitation therapy) }\end{array}$ \\
\hline Min 2002a & $\begin{array}{l}\text { Allocation: randomised } \\
\text { Participants: post stroke } \\
\text { Interventions: antidepressant versus psychological therapy, no placebo or usual care comparison }\end{array}$
\end{tabular}


(Continued)

\begin{tabular}{|c|c|}
\hline Miyai 1998 & $\begin{array}{l}\text { Allocation: randomised } \\
\text { Participants: post stroke } \\
\text { Interventions: no placebo comparison }\end{array}$ \\
\hline Niedermaier 2004 & $\begin{array}{l}\text { Allocation: randomised } \\
\text { Participants: post stroke } \\
\text { Interventions: no placebo comparison }\end{array}$ \\
\hline Nir 2004 & $\begin{array}{l}\text { Allocation: randomised } \\
\text { Participants: post stroke } \\
\text { Interventions: not talking therapy or sufficient training or supervision of 'therapists' }\end{array}$ \\
\hline Nour 2002 & $\begin{array}{l}\text { Allocation: randomised } \\
\text { Participants: post stroke } \\
\text { Interventions: home leisure educational programme, not meet review criteria, not structured or timetabled as } \\
\text { a talking therapy }\end{array}$ \\
\hline Ohtomo 1985 & $\begin{array}{l}\text { Allocation: randomised } \\
\text { Participants: post stroke } \\
\text { Interventions: tiapride with matched placebo for } 6 \text { weeks } \\
\text { Outcome: data not currently available }\end{array}$ \\
\hline Ostwald 2006 & $\begin{array}{l}\text { Allocation: randomised } \\
\text { Participants: post stroke patients and carers } \\
\text { Interventions: no usual care comparison }\end{array}$ \\
\hline Rampello 2004 & $\begin{array}{l}\text { Allocation: randomised } \\
\text { Participants: post stroke } \\
\text { Interventions: citalopram or reboxetine, no placebo control }\end{array}$ \\
\hline Ricauda 2004 & $\begin{array}{l}\text { Allocation: unclear } \\
\text { Participants: post stroke } \\
\text { Interventions: home hospitalisation service, does not meet review criteria }\end{array}$ \\
\hline Roberts 1995 & $\begin{array}{l}\text { Allocation: randomised } \\
\text { Participants: chronic illness } \\
\text { Interventions: no placebo comparison }\end{array}$ \\
\hline Rodgers 1999 & $\begin{array}{l}\text { Allocation: randomised } \\
\text { Participants: post stroke } \\
\text { Interventions: stroke education, did not meet review criteria, not structured or timetabled as a talking therapy }\end{array}$ \\
\hline Rudd 1997 & $\begin{array}{l}\text { Allocation: randomised } \\
\text { Participants: post stroke } \\
\text { Interventions: early hospital discharge, did not meet review criteria, not structured or timetabled as a talking } \\
\text { therapy }\end{array}$ \\
\hline
\end{tabular}


(Continued)

\begin{tabular}{ll}
\hline Rønning 1998 & $\begin{array}{l}\text { Allocation: randomised } \\
\text { Participants: post stroke } \\
\text { Interventions: subacute rehabilitation, did not meet review criteria, not structured or timetabled as a talking } \\
\text { therapy }\end{array}$ \\
\hline Sandberg 2001 & $\begin{array}{l}\text { Allocation: randomised } \\
\text { Participants: post stroke } \\
\text { Interventions: cPAP, did not meet review criteria }\end{array}$ \\
\hline Seliger 1990 & $\begin{array}{l}\text { Allocation: not randomised } \\
\text { Participants: post stroke and multiple sclerosis } \\
\text { Interventions: no placebo comparison }\end{array}$ \\
\hline
\end{tabular}

\begin{tabular}{ll} 
Shan 2001 & Allocation: randomised \\
Participants: post stroke & Interventions: fluoxetine versus acetamidepyrrolidone, no placebo control \\
\hline
\end{tabular}

$\begin{array}{ll}\text { Sivenius } 2001 & \text { Allocation: randomised } \\ & \text { Participants: acute post stroke } \\ & \text { Interventions: did not meet review criteria (acute treatment) } \\ & \text { Outcome: depression not primary endpoint }\end{array}$

\begin{tabular}{ll} 
Smedley 1986 & $\begin{array}{l}\text { Allocation: randomised } \\
\text { Participants: post stroke } \\
\text { Interventions: slot machines, did not meet review criteria }\end{array}$ \\
\hline Smith 2004 & $\begin{array}{l}\text { Allocation: randomised } \\
\text { Participants: post stroke (combined depressed and not depressed) } \\
\text { Intervention: education, did not meet review criteria }\end{array}$ \\
\hline Song 1999 & $\begin{array}{l}\text { Allocation: randomised } \\
\text { Participants: post stroke } \\
\text { Interventions: scalp acupuncture, did not meet review criteria }\end{array}$ \\
\hline Su 2004 & $\begin{array}{l}\text { Allocation: randomised } \\
\text { Participants: post stroke } \\
\text { Interventions: rehabilitation plus psychotherapy versus rehabilitation but rehabilitation includes fluoxetine }\end{array}$ \\
\hline Sulch 2000 & $\begin{array}{l}\text { Allocation: randomised } \\
\text { Participants: post stroke } \\
\text { Interventions: integrated managed care pathway, did not meet review criteria, not structured or timetabled as } \\
\text { a talking therapy }\end{array}$ \\
\hline Sulch 2002 & $\begin{array}{l}\text { Allocation: randomised } \\
\text { Participants: post stroke } \\
\text { Interventions: integrated managed care pathway, did not meet review criteria, not structured or timetabled as } \\
\text { a talking therapy }\end{array}$ \\
\hline
\end{tabular}


(Continued)

\begin{tabular}{|c|c|}
\hline Suskin 2006 & $\begin{array}{l}\text { Allocation: randomised } \\
\text { Participants: post stroke or transient ischaemic attack } \\
\text { Interventions: cardiac rehabilitation, not meet review criteria }\end{array}$ \\
\hline Suzuki 2001 & $\begin{array}{l}\text { Allocation: randomised } \\
\text { Participants: post stroke } \\
\text { Interventions: no placebo comparison }\end{array}$ \\
\hline Tan 2004 & $\begin{array}{l}\text { Allocation: unclear } \\
\text { Participants: post stroke } \\
\text { Interventions: provide comfortable environment, nutrition and medication instruction, rehabilitation training } \\
\text { and education, did not meet review criteria }\end{array}$ \\
\hline Taragano 2001 & $\begin{array}{l}\text { Allocation: randomised } \\
\text { Participants: post stroke } \\
\text { Interventions: no placebo comparison (both groups received fluoxetine, half received additional nimodipine, } \\
\text { half additional placebo) }\end{array}$ \\
\hline Wade 1992 & $\begin{array}{l}\text { Allocation: randomised } \\
\text { Participants: post stroke } \\
\text { Interventions: physiotherapy, did not meet review criteria, not structured or timetabled as a talking therapy }\end{array}$ \\
\hline Walker-Batson 1995 & $\begin{array}{l}\text { Allocation: randomised } \\
\text { Participants: post stroke } \\
\text { Interventions: dextroamphetamine versus placebo paired with physical therapy } \\
\text { Outcome: not depression }\end{array}$ \\
\hline Walsh 1999 & $\begin{array}{l}\text { Allocation: unclear } \\
\text { Participants: post stroke } \\
\text { Interventions: relaxation versus aromatherapy versus reflexology versus aromatherapy + reflexology, not meet } \\
\text { review criteria }\end{array}$ \\
\hline
\end{tabular}

\begin{tabular}{|c|c|}
\hline Wang 2002 & $\begin{array}{l}\text { Allocation: random } \\
\text { Participants: post stroke } \\
\text { Interventions: yukangning versus usual care, no placebo control }\end{array}$ \\
\hline
\end{tabular}

\begin{tabular}{ll}
\hline Wang 2003 & $\begin{array}{l}\text { Allocation: unclear } \\
\text { Participants: post stroke } \\
\text { Interventions: prozac versus amitriptyline versus usual care, no placebo comparison }\end{array}$ \\
\hline Wang 2004 & $\begin{array}{l}\text { Allocation: randomised } \\
\text { Participants: post stroke } \\
\text { Interventions: paroxetine, no placebo control }\end{array}$ \\
\hline
\end{tabular}

Wang $2007 \quad$ Allocation: randomised

Participants: post stroke

Interventions: yiyu, routine care + neurstan, no placebo control 
(Continued)

\begin{tabular}{ll}
\hline Werner 1996 & $\begin{array}{l}\text { Allocation: randomised } \\
\text { Participants: post stroke } \\
\text { Interventions: outpatient rehabilitation, did not meet review criteria, not structured or timetabled as a talking } \\
\text { therapy }\end{array}$ \\
\hline Wheeler 2003 & $\begin{array}{l}\text { Allocation: unclear } \\
\text { Participants: post stroke } \\
\text { Interventions: music therapy, not meet review criteria }\end{array}$ \\
\hline
\end{tabular}

\begin{tabular}{l} 
Wiart 1997 \\
$\begin{array}{l}\text { Allocation: randomised } \\
\text { Participants: post stroke } \\
\text { Interventions: no placebo comparison }\end{array}$ \\
\hline
\end{tabular}

\begin{tabular}{ll}
\hline Williams 2002 & Allocation: randomised \\
& Participants: post stroke \\
& Interventions: no placebo comparison \\
\hline
\end{tabular}

\begin{tabular}{ll} 
Wolfe 2000 & $\begin{array}{l}\text { Allocation: randomised } \\
\text { Participants: post stroke } \\
\text { Interventions: community based rehabilitation, did not meet review criteria, not structured or timetabled as } \\
\text { a talking therapy }\end{array}$ \\
\hline Wu 2002 & $\begin{array}{l}\text { Allocation: random } \\
\text { Participants: post stroke } \\
\text { Interventions: fluoxetine plus usual care versus usual care, no placebo comparison }\end{array}$ \\
\hline
\end{tabular}

\begin{tabular}{ll}
\hline Xia 2003 & $\begin{array}{l}\text { Allocation: random } \\
\text { Participants: post stroke } \\
\text { Interventions: some patients in the intervention group received antidepressants, no one in the control group } \\
\text { did }\end{array}$ \\
\hline Xiaoying 2001 & $\begin{array}{l}\text { Allocation: randomised } \\
\text { Participants: post stroke } \\
\text { Interventions: no placebo comparison for antidepressants }\end{array}$ \\
\hline
\end{tabular}

\begin{tabular}{l} 
Xie $2003 \quad \begin{array}{l}\text { Allocation: unclear } \\
\text { Participants: post stroke but unclear whether includes only depressed, or mixed patients } \\
\text { Interventions: psychological intervention: feeling support therapy, recognition therapy, collective therapy, } \\
\text { social support and skills training }\end{array}$ \\
\hline
\end{tabular}

\begin{tabular}{ll}
\hline Xie 2005 & $\begin{array}{l}\text { Allocation: randomised } \\
\text { Participants: post stroke } \\
\text { Interventions: sertraline, no placebo control }\end{array}$ \\
\hline Xing 1999 & $\begin{array}{l}\text { Allocation: random } \\
\text { Participants: post stroke } \\
\text { Interventions: fluoxetine plus routine drug therapy and rehabilitation versus routine drug therapy and reha- } \\
\text { bilitation, no placebo }\end{array}$
\end{tabular}




\begin{tabular}{|c|c|}
\hline Xu 2001 & $\begin{array}{l}\text { Allocation: random } \\
\text { Participants: post stroke } \\
\text { Interventions: fluoxetine, rehabilitation, neurological drugs and psychotherapy versus rehabilitation, neuro- } \\
\text { logical drugs and psychotherapy, no placebo control }\end{array}$ \\
\hline Ye 2004 & $\begin{array}{l}\text { Allocation: random } \\
\text { Participants: post stroke } \\
\text { Interventions: paroxetine versus imipramine versus usual care, no placebo comparison }\end{array}$ \\
\hline Yi 1990 & $\begin{array}{l}\text { Allocation: randomised } \\
\text { Participants: post stroke } \\
\text { Interventions: no placebo comparison }\end{array}$ \\
\hline Yokokawa 1991 & $\begin{array}{l}\text { Allocation: randomised } \\
\text { Participants: post stroke } \\
\text { Interventions: physical activity, did not meet review criteria, not structured or timetabled as a talking therapy }\end{array}$ \\
\hline Yoneyama 1993 & $\begin{array}{l}\text { Allocation: randomised } \\
\text { Participants: post stroke } \\
\text { Interventions: no placebo comparison }\end{array}$ \\
\hline You 2002 & $\begin{array}{l}\text { Allocation: randomised } \\
\text { Participants: post stroke } \\
\text { Interventions: rehabilitation plus antidepressant versus rehabilitation versus drug therapy alone, no placebo } \\
\text { control }\end{array}$ \\
\hline Young 1992 & $\begin{array}{l}\text { Allocation: randomised } \\
\text { Participants: post stroke } \\
\text { Interventions: no placebo comparison }\end{array}$ \\
\hline Yu 1991 & $\begin{array}{l}\text { Allocation: unclear } \\
\text { Participants: post stroke (some) } \\
\text { Interventions: prompted toileting + social reinforcement versus control, not meet review criteria }\end{array}$ \\
\hline Zhang 2000 & $\begin{array}{l}\text { Allocation: unclear } \\
\text { Participants: post stroke } \\
\text { Interventions: psychological therapy plus paroxetine versus psychological therapy }\end{array}$ \\
\hline Zhang 2002 & $\begin{array}{l}\text { Allocation: randomised } \\
\text { Participants: post stroke } \\
\text { Interventions: no placebo comparison }\end{array}$ \\
\hline Zhang 2002a & $\begin{array}{l}\text { Allocation: randomised } \\
\text { Participants: post stroke } \\
\text { Interventions: no placebo comparison }\end{array}$ \\
\hline
\end{tabular}


(Continued)

\begin{tabular}{|c|c|}
\hline Zhang 2002b & $\begin{array}{l}\text { Allocation: randomised } \\
\text { Participants: post stroke } \\
\text { Interventions: fluoxetine plus usual care versus usual care, no placebo comparison }\end{array}$ \\
\hline Zhang 2005 & $\begin{array}{l}\text { Allocation: random } \\
\text { Participants: post stroke } \\
\text { Interventions: buspirone hydrocholride versus usual care, no placebo comparison }\end{array}$ \\
\hline Zhang 2005a & $\begin{array}{l}\text { Allocation: randomised } \\
\text { Participants: post stroke } \\
\text { Interventions: acupuncture versus fluoxetine, no placebo comparison }\end{array}$ \\
\hline Zhao 1999 & $\begin{array}{l}\text { Allocation: randomised } \\
\text { Participants: post stroke } \\
\text { Interventions: no placebo comparison }\end{array}$ \\
\hline Zhao 2005 & $\begin{array}{l}\text { Allocation: random } \\
\text { Participants: post stroke } \\
\text { Interventions: citalopram versus venlafaxing, no placebo comparison }\end{array}$ \\
\hline Zhao 2005a & $\begin{array}{l}\text { Allocation: randomised } \\
\text { Participants: post stroke } \\
\text { Interventions: citalopram versus amitriptyline, no placebo comparison }\end{array}$ \\
\hline Zhou 2003 & $\begin{array}{l}\text { Allocation: unclear } \\
\text { Participants: post stroke } \\
\text { Interventions: fluoxetine and rehabilitation training, no placebo comparison }\end{array}$ \\
\hline Zhou 2004 & $\begin{array}{l}\text { Allocation: random } \\
\text { Participants: post stroke } \\
\text { Interventions: therapist (not defined, no training or supervision stated) led strategy involving lots of people } \\
\text { including family and a buddy system }\end{array}$ \\
\hline Zhu 2002 & $\begin{array}{l}\text { Allocation: random } \\
\text { Participants: post stroke } \\
\text { Interventions: fluoxetine plus usual care versus usual care, no placebo comparison }\end{array}$ \\
\hline Zifko 2002 & $\begin{array}{l}\text { Allocation: not randomised } \\
\text { Participants: post stroke } \\
\text { Interventions: no placebo comparison }\end{array}$ \\
\hline
\end{tabular}




\section{Characteristics of ongoing studies [ordered by study ID]}

\section{Graven 2008}

\begin{tabular}{|c|c|}
\hline Trial name or title & $\begin{array}{l}\text { Parallel design } \\
\text { Method of randomisation: computer generated randomisation table } \\
\text { Method of concealment: sealed opaque envelopes } \\
\text { Blinding } \\
\text { Participants: yes } \\
\text { Outcome assessors: yes } \\
\text { Statisticians: yes }\end{array}$ \\
\hline \multicolumn{2}{|l|}{ Methods } \\
\hline Participants & $\begin{array}{l}\text { Location: Australia } \\
\text { Setting: unclear } \\
\text { Stroke criteria: ischaemic and haemorrhagic stroke } \\
\text { Other entry criteria: unclear }\end{array}$ \\
\hline Interventions & $\begin{array}{l}\text { Treatment: rehabilitation, goal setting, problem solving, facilitated referral to services, promotion of health } \\
\text { lifestyle, self efficacy and self reliance } \\
\text { Control: active control, usual care plus phone contact with allied health professional three times for support } \\
\text { and encouragement } \\
\text { Duration: treatment duration: minimum of } 4 \text {, maximum of } 12\end{array}$ \\
\hline Outcomes & Depression: Geriatric Depression Scale \\
\hline Starting date & 2008 \\
\hline Contact information & $\begin{array}{l}\text { Christine Graven } \\
\text { Physiotherapy Department } \\
\text { St. Vincent's Health Melbourne } \\
\text { PO Box } 2900 \\
\text { Fitzroy } 3065 \\
\text { Victoria } \\
\text { Tel: +61 } 392883927 \\
\text { Christine.GRAVEN@svhm.org.au }\end{array}$ \\
\hline Notes & Exclusion criteria: unclear \\
\hline
\end{tabular}

\section{Mitchell 2002}

$\begin{array}{ll}\text { Trial name or title } & \text { Parallel design } \\ & \text { Method of randomisation: unclear } \\ & \text { Method of concealment: unclear } \\ & \text { Blinding: single blind }\end{array}$

Methods 
Mitchell 2002 (Continued)

\begin{tabular}{ll}
\hline Participants & $\begin{array}{l}\text { Location: USA } \\
\text { Setting: unclear } \\
\text { Stroke criteria: ischaemic stroke } \\
\text { Other entry criteria: stroke within } 4 \text { months, 21 years of age and above }\end{array}$ \\
\hline Interventions & $\begin{array}{l}\text { Treatment: cognitive behavioral therapy plus problem-solving } \\
\text { Control: active control, standard antidepressant treatment and written material } \\
\text { Duration: treatment duration: 9 sessions over 7 weeks }\end{array}$ \\
\hline Outcomes & Depression: HDRS \\
\hline Starting date & March 2002 \\
\hline Contact information & $\begin{array}{l}\text { Pamela H Mitchell } \\
\text { University of Washington } \\
\text { Seattle } \\
\text { Washington } 98195-7266 \\
\text { USA }\end{array}$ \\
\hline Notes & $\begin{array}{l}\text { Exclusion criteria: subarachnoid or intracranial hemorrhagic stroke, global aphasia, reduced level of con- } \\
\text { sciousness (GCS < 15) } \\
\text { NCT00194454 }\end{array}$ \\
\hline
\end{tabular}

Thomas 2007

\begin{tabular}{|c|c|}
\hline Trial name or title & $\begin{array}{l}\text { Parallel design } \\
\text { Method of randomisation: unclear } \\
\text { Method of concealment: unclear } \\
\text { Blinding: unclear }\end{array}$ \\
\hline \multicolumn{2}{|l|}{ Methods } \\
\hline Participants & $\begin{array}{l}\text { Location: UK } \\
\text { Setting: unclear } \\
\text { Stroke criteria: unclear }\end{array}$ \\
\hline Interventions & $\begin{array}{l}\text { Treatment 1: behavioural psychotherapy } \\
\text { Control 1: attention control } \\
\text { Control 2: no intervention } \\
\text { Duration: unclear }\end{array}$ \\
\hline Outcomes & Depression: unclear \\
\hline Starting date & April 2005 \\
\hline Contact information & $\begin{array}{l}\text { Miss Shirley Thomas } \\
\text { Research Associate } \\
\text { Division of Rehabilitation and Ageing }\end{array}$ \\
\hline
\end{tabular}


Thomas 2007 (Continued)

B Floor Medical School

Queens Medical Centre

Nottingham NG7 2UH

UK

shirley.thomas@nottingham.ac.uk

Notes $\quad$ Exclusion criteria: unclear

HDRS: Hamilton Depression Rating Scale 
DATA AND ANALYSES

Comparison 1. Pharmaceutical interventions versus placebo (antidepressants)

\begin{tabular}{|c|c|c|c|c|}
\hline Outcome or subgroup title & $\begin{array}{l}\text { No. of } \\
\text { studies }\end{array}$ & $\begin{array}{c}\text { No. of } \\
\text { participants }\end{array}$ & Statistical method & Effect size \\
\hline $\begin{array}{l}1 \text { Depression: } 1 \text {. Meeting study } \\
\text { criteria for depression }\end{array}$ & 7 & 789 & Odds Ratio (M-H, Random, 95\% CI) & $0.47[0.22,0.98]$ \\
\hline $\begin{array}{l}1.1 \text { Clinician } \\
\text { interview/impression (number } \\
\text { improved) }\end{array}$ & 1 & 206 & Odds Ratio (M-H, Random, 95\% CI) & $0.47[0.27,0.83]$ \\
\hline 1.2 DSM-III & 1 & 26 & Odds Ratio (M-H, Random, 95\% CI) & $1.05[0.22,5.00]$ \\
\hline 1.3 HDRS & 3 & 209 & Odds Ratio (M-H, Random, 95\% CI) & $0.21[0.03,1.40]$ \\
\hline 1.4 MADRS & 2 & 348 & Odds Ratio (M-H, Random, 95\% CI) & $0.84[0.27,2.62]$ \\
\hline $\begin{array}{l}2 \text { Depression: } 2 \text {. Average change } \\
\text { in scores between baseline and } \\
\text { end of treatment }\end{array}$ & 8 & & Mean Difference (IV, Fixed, 95\% CI) & Totals not selected \\
\hline $\begin{array}{l}2.1 \mathrm{BDI} \text { (high score = more } \\
\text { depressed) }\end{array}$ & 2 & & Mean Difference (IV, Fixed, 95\% CI) & Not estimable \\
\hline $\begin{array}{l}\text { 2.2 CGI (low score }= \\
\text { improvement } / \text { high score }= \\
\text { deterioration) }\end{array}$ & 1 & & Mean Difference (IV, Fixed, 95\% CI) & Not estimable \\
\hline $\begin{array}{l}2.3 \text { HDRS (high score = more } \\
\text { depressed) }\end{array}$ & 5 & & Mean Difference (IV, Fixed, 95\% CI) & Not estimable \\
\hline $\begin{array}{l}2.4 \text { MADRS (high score }= \\
\text { more depressed) }\end{array}$ & 3 & & Mean Difference (IV, Fixed, 95\% CI) & Not estimable \\
\hline $\begin{array}{l}\text { 2.5 Melancholia scale (high } \\
\text { score = more depressed) }\end{array}$ & 1 & & Mean Difference (IV, Fixed, 95\% CI) & Not estimable \\
\hline $\begin{array}{l}\text { 2.6 Zung (high score = more } \\
\text { depressed) }\end{array}$ & 1 & & Mean Difference (IV, Fixed, 95\% CI) & Not estimable \\
\hline $\begin{array}{l}3 \text { Depression: } 3 \text {. Mean scores at } \\
\text { end of treatment }\end{array}$ & 8 & & Mean Difference (IV, Fixed, 95\% CI) & Totals not selected \\
\hline $\begin{array}{l}\text { 3.1 BDI (high score = more } \\
\text { depressed) }\end{array}$ & 2 & & Mean Difference (IV, Fixed, 95\% CI) & Not estimable \\
\hline $\begin{array}{l}\text { 3.2 CGI (low score }= \\
\text { improvement } / \text { high score }= \\
\text { deterioration) }\end{array}$ & 1 & & Mean Difference (IV, Fixed, 95\% CI) & Not estimable \\
\hline $\begin{array}{l}3.3 \text { HDRS (high score = more } \\
\text { depressed) }\end{array}$ & 6 & & Mean Difference (IV, Fixed, 95\% CI) & Not estimable \\
\hline $\begin{array}{l}3.4 \text { MADRS (high score }= \\
\text { more depressed) }\end{array}$ & 2 & & Mean Difference (IV, Fixed, 95\% CI) & Not estimable \\
\hline $\begin{array}{l}3.5 \text { Melancholia scale (high } \\
\text { score = more depressed) }\end{array}$ & 1 & & Mean Difference (IV, Fixed, 95\% CI) & Not estimable \\
\hline $\begin{array}{l}\text { 3.6 Zung (high score = more } \\
\text { depressed) }\end{array}$ & 1 & & Mean Difference (IV, Fixed, 95\% CI) & Not estimable \\
\hline $\begin{array}{l}4 \text { Depression: } 4 . \text { Less than } 50 \% \\
\text { reduction in scale scores }\end{array}$ & 5 & 414 & Odds Ratio (M-H, Random, 95\% CI) & $0.22[0.09,0.52]$ \\
\hline $4.1 \mathrm{HDRS}$ & 3 & 260 & Odds Ratio (M-H, Random, 95\% CI) & $0.13[0.06,0.30]$ \\
\hline
\end{tabular}

Copyright $\odot 2008$ The Cochrane Collaboration. Published by John Wiley \& Sons, Ltd. 


$$
\text { 4.2 MADRS }
$$

5 Anxiety: 1. Meeting study criteria for anxiety

5.1 Clinician interview/impression

6 Cognitive functioning: 1 . Average change in scores between baseline and end of treatment

6.1 MMSE (low score $=$ cognitive impairment)

7 Cognitive functioning: 2. Mean scores at end of treatment

7.1 MMSE (low score $=$ cognitive impairment)

8 Activities of daily living: 1 . Average change in scores between baseline and end of treatment

8.1 Barthel (high score $=$ more dependent)

9 Disability: 1. Average change in scores between baseline and end of treatment

9.1 Functional Independence Measure (low score $=$

dependence)

9.2 Motoricity Index

(low score $=$ more motor impairment)

9.3 Scandinavian Stroke Scale (low score $=$ more neurological deficit)

9.4 Rankin Scale (high score = more disability)

10 Disability: 2. Mean scores at end of treatment

10.1 Functional Independence

Measure (low score $=$

dependence)

10.2 Motoricity Index

(low score $=$ more motor

impairment)

10.3 Scandinavian Stroke

Scale (low score $=$ more neurological deficit)

11 Neurological function: 1. Average change in scores between baseline and end of treatment
Odds Ratio (M-H, Random, 95\% CI)

Odds Ratio (M-H, Fixed, 95\% CI)

Odds Ratio (M-H, Fixed, 95\% CI)

Mean Difference (IV, Fixed, 95\% CI)

Mean Difference (IV, Fixed, 95\% CI)

Mean Difference (IV, Fixed, 95\% CI)

Mean Difference (IV, Fixed, 95\% CI)

Mean Difference (IV, Fixed, 95\% CI)

Mean Difference (IV, Fixed, 95\% CI)

Mean Difference (IV, Fixed, 95\% CI)

Mean Difference (IV, Fixed, 95\% CI)

Mean Difference (IV, Fixed, 95\% CI)

Mean Difference (IV, Fixed, 95\% CI)

Mean Difference (IV, Fixed, 95\% CI)

Mean Difference (IV, Fixed, 95\% CI)

Mean Difference (IV, Fixed, 95\% CI)

Mean Difference (IV, Fixed, 95\% CI)

Mean Difference (IV, Fixed, 95\% CI)

Mean Difference (IV, Fixed, 95\% CI)
$0.52[0.27,1.00]$

Totals not selected

Not estimable

Totals not selected

Not estimable

Totals not selected

Not estimable

Totals not selected

Not estimable

Totals not selected

Not estimable

Not estimable

Not estimable

Not estimable

Totals not selected

Not estimable

Not estimable

Not estimable

Totals not selected 
11.1 Chinese Stroke Scale

(high score = more impairment)

12 Neurological function: 2. Mean scores at end of treatment

12.1 Chinese Stroke Scale

(high score $=$ more impairment)

13 Adverse events: 1. Death 13.1 At end of treatment

14 Adverse events: 2. All

14.1 Central nervous system

events (e.g. confusion, sedation, tremor)

14.2 Gastrointestinal effects (e.g. constipation, diarrhoea)

14.3 Other events - not listed above (e.g. dysuria, eye discomfort)

14.4 Protocol violation (e.g. refused treatment, withdrew consent)

14.5 Psychiatric events (e.g. anxiety, increased depression)

14.6 Recurrent stroke

14.7 Vascular events -

not stroke (e.g. dizziness, palpitation)

15 Adverse events: 3. Leaving the study early (including death)

15.1 all drop outs and withdrawals
Mean Difference (IV, Fixed, 95\% CI)

Mean Difference (IV, Fixed, 95\% CI)

Mean Difference (IV, Fixed, 95\% CI)

Odds Ratio (M-H, Fixed, 95\% CI)

Odds Ratio (M-H, Fixed, 95\% CI)

Odds Ratio (M-H, Fixed, 95\% CI)

488

Odds Ratio (M-H, Fixed, 95\% CI)

Odds Ratio (M-H, Fixed, 95\% CI)

Odds Ratio (M-H, Fixed, 95\% CI)

Odds Ratio (M-H, Fixed, 95\% CI)

Odds Ratio (M-H, Fixed, 95\% CI)

Odds Ratio (M-H, Fixed, 95\% CI)

Odds Ratio (M-H, Fixed, 95\% CI)

Odds Ratio (M-H, Fixed, 95\% CI)

542

Odds Ratio (M-H, Fixed, 95\% CI)
Not estimable

Totals not selected

Not estimable

Subtotals only $0.57[0.15,2.15]$

Subtotals only

$1.96[1.19,3.24]$

$2.37[1.38,4.06]$

$1.51[0.97,2.34]$

$0.85[0.20,3.66]$

$0.35[0.03,3.47]$

$1.14[0.15,8.60]$

$1.60[0.93,2.73]$

Subtotals only

$1.04[0.69,1.59]$

\section{Comparison 2. Pharmaceutical interventions versus placebo (combination therapy)}

\begin{tabular}{|c|c|c|c|c|}
\hline Outcome or subgroup title & $\begin{array}{l}\text { No. of } \\
\text { studies }\end{array}$ & $\begin{array}{l}\text { No. of } \\
\text { participants }\end{array}$ & Statistical method & Effect size \\
\hline $\begin{array}{l}1 \text { Depression: } 1 \text {. Average change } \\
\text { in scores between baseline and } \\
\text { end of treatment }\end{array}$ & 1 & & Mean Difference (IV, Fixed, 95\% CI) & Totals not selected \\
\hline $\begin{array}{l}\text { 1.1 HDRS (high score = more } \\
\text { depressed) }\end{array}$ & 1 & & Mean Difference (IV, Fixed, 95\% CI) & Not estimable \\
\hline $\begin{array}{l}2 \text { Depression: } 2 . \text { Mean scores at } \\
\text { end of treatment }\end{array}$ & 1 & & Mean Difference (IV, Fixed, 95\% CI) & Totals not selected \\
\hline $\begin{array}{l}2.1 \text { HDRS (high score = more } \\
\text { depressed) }\end{array}$ & 1 & & Mean Difference (IV, Fixed, 95\% CI) & Not estimable \\
\hline $\begin{array}{l}3 \text { Neurological function: } 1 . \\
\text { Average change in scores } \\
\text { between baseline and end of } \\
\text { treatment }\end{array}$ & 1 & & Mean Difference (IV, Fixed, 95\% CI) & Totals not selected \\
\hline
\end{tabular}

Interventions for treating depression after stroke (Review)

Copyright ( 2008 The Cochrane Collaboration. Published by John Wiley \& Sons, Ltd. 


\subsection{Chinese Stroke Scale (high score $=$ more impairment)}

4 Neurological function: 2. Mean 1 scores at end of treatment 4.1 Chinese Stroke Scale (high 1 score $=$ more impairment)

5 Adverse events: 1 . All 5.1 Other events (GPT elevation)

5.2 Vascular events - not stroke (e.g. ECG changes)
Mean Difference (IV, Fixed, 95\% CI)

Mean Difference (IV, Fixed, 95\% CI)

Mean Difference (IV, Fixed, 95\% CI)

Odds Ratio (M-H, Fixed, 95\% CI)

Odds Ratio (M-H, Fixed, 95\% CI)

Odds Ratio (M-H, Fixed, 95\% CI)
Not estimable

Totals not selected

Not estimable

$2.14[0.23,19.95]$

$2.72[0.12,60.29]$

$1.58[0.06,41.03]$

\section{Comparison 3. Psychological interventions versus standard care and/or attention control}

\begin{tabular}{|c|c|c|c|c|}
\hline Outcome or subgroup title & $\begin{array}{l}\text { No. of } \\
\text { studies }\end{array}$ & $\begin{array}{c}\text { No. of } \\
\text { participants }\end{array}$ & Statistical method & Effect size \\
\hline $\begin{array}{l}1 \text { Depression: Meeting study } \\
\text { criteria for depression at end of } \\
\text { treatment }\end{array}$ & 1 & & Odds Ratio (M-H, Fixed, 95\% CI) & Totals not selected \\
\hline $\begin{array}{c}1.1 \text { GHQ-28 (high score = } \\
\text { greater psychological distress) }\end{array}$ & 1 & & Odds Ratio (M-H, Fixed, 95\% CI) & Not estimable \\
\hline $\begin{array}{l}2 \text { Depression: } 1 \text {. Average change } \\
\text { in scores between baseline and } \\
\text { end of treatment }\end{array}$ & 2 & & Mean Difference (IV, Fixed, 95\% CI) & Totals not selected \\
\hline $\begin{array}{l}2.1 \text { BDI (high score = more } \\
\text { depressed) }\end{array}$ & 1 & & Mean Difference (IV, Fixed, 95\% CI) & Not estimable \\
\hline $\begin{array}{l}2.2 \text { WDI (high score = more } \\
\text { depressed) }\end{array}$ & 1 & & Mean Difference (IV, Fixed, 95\% CI) & Not estimable \\
\hline $\begin{array}{l}2.3 \text { HDRS (high score }=\text { more } \\
\text { depressed) }\end{array}$ & 1 & & Mean Difference (IV, Fixed, 95\% CI) & Not estimable \\
\hline $\begin{array}{l}3 \text { Depression: } 2 . \text { Mean scores at } \\
\text { end of treatment }\end{array}$ & 2 & & Mean Difference (IV, Fixed, 95\% CI) & Totals not selected \\
\hline $\begin{array}{l}\text { 3.1 BDI (high score = more } \\
\text { depressed) }\end{array}$ & 1 & & Mean Difference (IV, Fixed, 95\% CI) & Not estimable \\
\hline $\begin{array}{l}3.2 \text { WDI (high score = more } \\
\text { depressed) }\end{array}$ & 1 & & Mean Difference (IV, Fixed, 95\% CI) & Not estimable \\
\hline $\begin{array}{l}\text { 3.3 HDRS (high score }=\text { more } \\
\text { depressed) }\end{array}$ & 1 & & Mean Difference (IV, Fixed, 95\% CI) & Not estimable \\
\hline $\begin{array}{l}4 \text { Psychological distress: } 1 . \text { Average } \\
\text { change in scores between } \\
\text { baseline and end of treatment }\end{array}$ & 2 & & Mean Difference (IV, Fixed, 95\% CI) & Totals not selected \\
\hline $\begin{array}{c}\text { 4.1 GHQ-28 (high score = } \\
\text { greater psychological distress) }\end{array}$ & 2 & & Mean Difference (IV, Fixed, 95\% CI) & Not estimable \\
\hline $\begin{array}{l}5 \text { Psychological distress: } 2 . \text { Mean } \\
\text { scores at end of treatment }\end{array}$ & 1 & & Mean Difference (IV, Fixed, 95\% CI) & Totals not selected \\
\hline $\begin{array}{c}5.1 \text { GHQ-28 (high score = } \\
\text { greater psychological distress) }\end{array}$ & 1 & & Mean Difference (IV, Fixed, 95\% CI) & Not estimable \\
\hline
\end{tabular}

Interventions for treating depression after stroke (Review)

Copyright $\odot 2008$ The Cochrane Collaboration. Published by John Wiley \& Sons, Ltd. 
6 Activities of daily living: 1.

Average change in scores from

baseline to end of treatment

6.1 EADL (high score = more

dependent)

6.2 Barthel (high score $=$ more dependent)

7 Activities of daily living: 2. Mean scores at end of treatment

7.1 EADL (high score $=$ more dependent)

7.2 Barthel (high score $=$ more dependent)

8 Adverse events: 1 . Death 8.1 At end of treatment

9 Adverse events: 2. All

9.1 Protocol violation (e.g. refused treatment, withdrew consent)

\subsection{Recurrent stroke}

9.3 Vascular events - not stroke (e.g. transient ischaemic attack)

10 Adverse events: 3. Leaving the study early (including death)

10.1 All drop outs and withdrawals
Mean Difference (IV, Fixed, 95\% CI)

Mean Difference (IV, Fixed, 95\% CI)

Mean Difference (IV, Fixed, 95\% CI)

Mean Difference (IV, Fixed, 95\% CI)

Mean Difference (IV, Fixed, 95\% CI)

Mean Difference (IV, Fixed, 95\% CI)

Odds Ratio (M-H, Fixed, 95\% CI)

Odds Ratio (M-H, Fixed, 95\% CI)

Odds Ratio (M-H, Fixed, 95\% CI)

Odds Ratio (M-H, Fixed, 95\% CI)

Odds Ratio (M-H, Fixed, 95\% CI)

Odds Ratio (M-H, Fixed, 95\% CI)

Odds Ratio (M-H, Fixed, 95\% CI)

Odds Ratio (M-H, Fixed, 95\% CI)
Totals not selected

Not estimable

Not estimable

Totals not selected

Not estimable

Not estimable

Subtotals only $0.37[0.11,1.28]$

Subtotals only

$0.33[0.01,8.65]$

$5.08[0.24,106.87]$

$0.70[0.22,2.27]$

Subtotals only 
Analysis I.I. Comparison I Pharmaceutical interventions versus placebo (antidepressants), Outcome I Depression: I. Meeting study criteria for depression.

Review: Interventions for treating depression after stroke

Comparison: I Pharmaceutical interventions versus placebo (antidepressants)

Outcome: I Depression: I. Meeting study criteria for depression

\begin{tabular}{|c|c|c|c|c|c|}
\hline Study or subgroup & Treatment & Control & $\begin{array}{r}\text { Odds Ratio } \\
\text { M- } \\
\text { H,Random,95\% } \\
\text { Cl } \\
\end{array}$ & Weight & $\begin{array}{l}\text { Odds Ratio } \\
\text { M- } \\
\text { H,Random,95\% } \\
\text { Cl } \\
\end{array}$ \\
\hline \multicolumn{6}{|c|}{ I Clinician interview/impression (number improved) } \\
\hline Ohtomo 1991 & $52 / 108$ & $65 / 98$ & 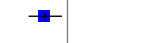 & $18.5 \%$ & $0.47[0.27,0.83]$ \\
\hline Subtotal $(95 \% \mathrm{CI})$ & 108 & 98 & & $18.5 \%$ & $0.47[0.27,0.83]$ \\
\hline \multicolumn{6}{|c|}{ Total events: 52 (Treatment), 65 (Control) } \\
\hline \multicolumn{6}{|c|}{ Heterogeneity: not applicable } \\
\hline \multicolumn{6}{|c|}{ Test for overall effect: $Z=2.61(P=0.0090)$} \\
\hline \multicolumn{6}{|c|}{2 DSM-III } \\
\hline Lipsey 1984 & $6 / 11$ & $8 / 15$ & - & $10.8 \%$ & $1.05[0.22,5.00]$ \\
\hline Subtotal (95\% CI) & 11 & 15 & & $10.8 \%$ & $1.05[0.22,5.00]$ \\
\hline \multicolumn{6}{|c|}{ Total events: 6 (Treatment), 8 (Control) } \\
\hline \multicolumn{6}{|c|}{ Heterogeneity: not applicable } \\
\hline \multicolumn{6}{|c|}{ Test for overall effect: $Z=0.06(P=0.95)$} \\
\hline \multicolumn{6}{|c|}{3 HDRS } \\
\hline Andersen 1994 & $6 / 18$ & $17 / 20$ & & $10.7 \%$ & $0.09[0.02,0.42]$ \\
\hline Fruehwald 2003 & $8 / 26$ & $6 / 24$ & 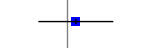 & $13.1 \%$ & $1.33[0.38,4.63]$ \\
\hline Yang 2002 & $33 / 64$ & $53 / 57$ & & $14.0 \%$ & $0.08[0.03,0.25]$ \\
\hline Subtotal (95\% CI) & 108 & 101 & & $37.7 \%$ & $0.21[0.03,1.40]$ \\
\hline \multicolumn{6}{|c|}{ Total events: 47 (Treatment), 76 (Control) } \\
\hline \multicolumn{6}{|c|}{ Heterogeneity: Tau $^{2}=2.29 ; \mathrm{Chi}^{2}=12.44, \mathrm{df}=2(\mathrm{P}=0.002) ; \mathrm{I}^{2}=84 \%$} \\
\hline \multicolumn{6}{|c|}{ Test for overall effect: $Z=1.61(P=0.11)$} \\
\hline \multicolumn{6}{|c|}{4 MADRS } \\
\hline Murray 2002 & $12 / 62$ & $8 / 61$ & 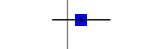 & $15.2 \%$ & $1.59[0.60,4.21]$ \\
\hline Ponzio 2001 & $82 / 111$ & $97 / 114$ & $\rightarrow$ & $17.7 \%$ & $0.50[0.25,0.97]$ \\
\hline Subtotal (95\% CI) & 173 & 175 & & $33.0 \%$ & $0.84[0.27,2.62]$ \\
\hline \multicolumn{6}{|c|}{ Total events: 94 (Treatment), 105 (Control) } \\
\hline \multicolumn{6}{|c|}{ Heterogeneity: $\operatorname{Tau}^{2}=0.50 ; \mathrm{Chi}^{2}=3.74, \mathrm{df}=1(P=0.05) ;\left.\right|^{2}=73 \%$} \\
\hline \multicolumn{6}{|c|}{ Test for overall effect: $Z=0.30(P=0.76)$} \\
\hline Total (95\% CI) & 400 & 389 & & $100.0 \%$ & $0.47[0.22,0.98]$ \\
\hline \multicolumn{6}{|c|}{ Total events: 199 (Treatment), 254 (Control) } \\
\hline \multicolumn{6}{|c|}{ Heterogeneity: $\mathrm{Tau}^{2}=0.68 ; \mathrm{Chi}^{2}=23.60, \mathrm{df}=6(\mathrm{P}=0.00062) ;\left.\right|^{2}=75 \%$} \\
\hline Test for overall effect: $Z=$ & $=0.043)$ & & & & \\
\hline
\end{tabular}

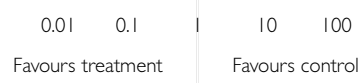


Analysis I.2. Comparison I Pharmaceutical interventions versus placebo (antidepressants), Outcome 2 Depression: 2. Average change in scores between baseline and end of treatment.

Review: Interventions for treating depression after stroke
Comparison: I Pharmaceutical interventions versus placebo (antidepressants)
Outcome: 2 Depression: 2. Average change in scores between baseline and end of treatment

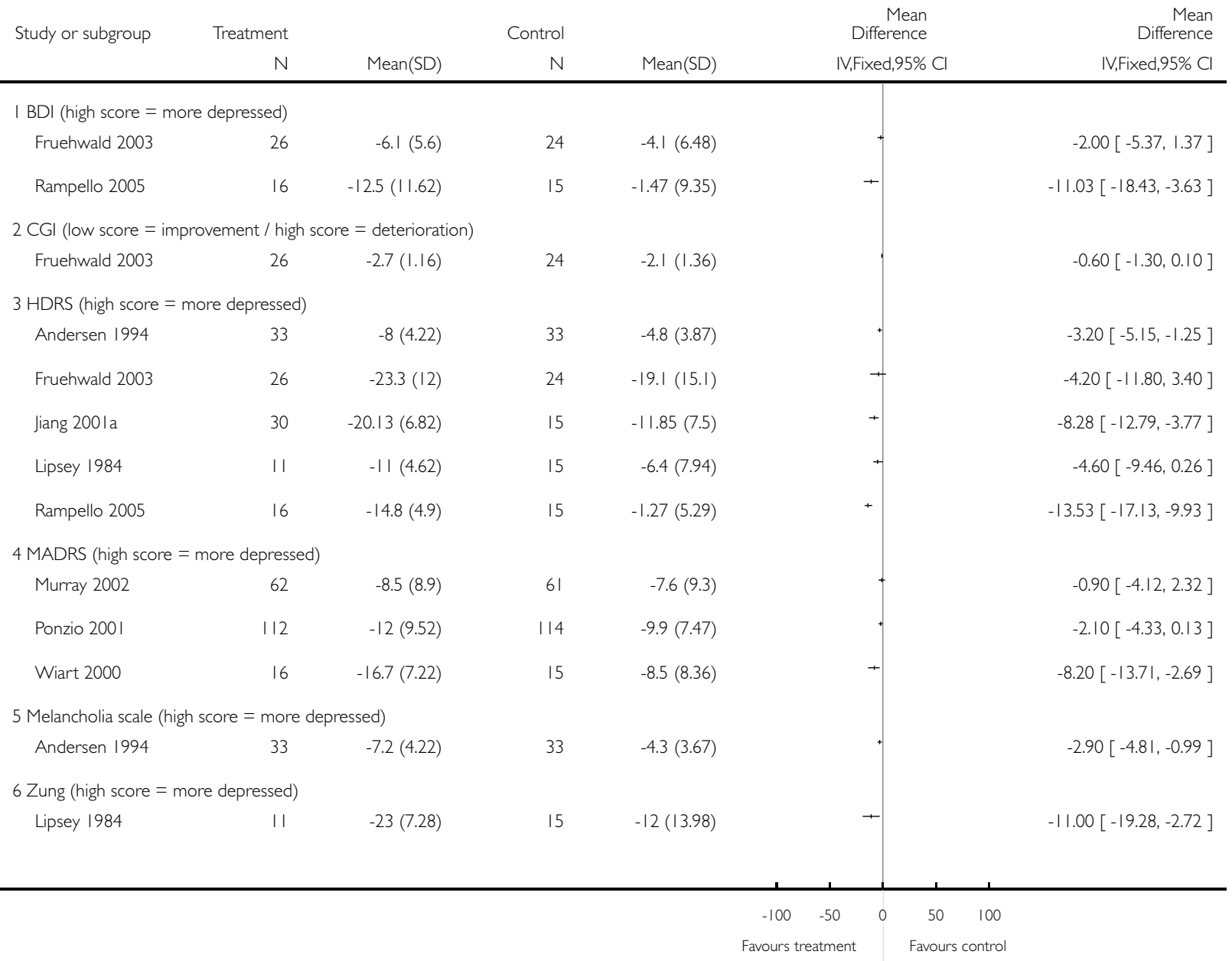




\section{Analysis I.3. Comparison I Pharmaceutical interventions versus placebo (antidepressants), Outcome 3 Depression: 3. Mean scores at end of treatment.}

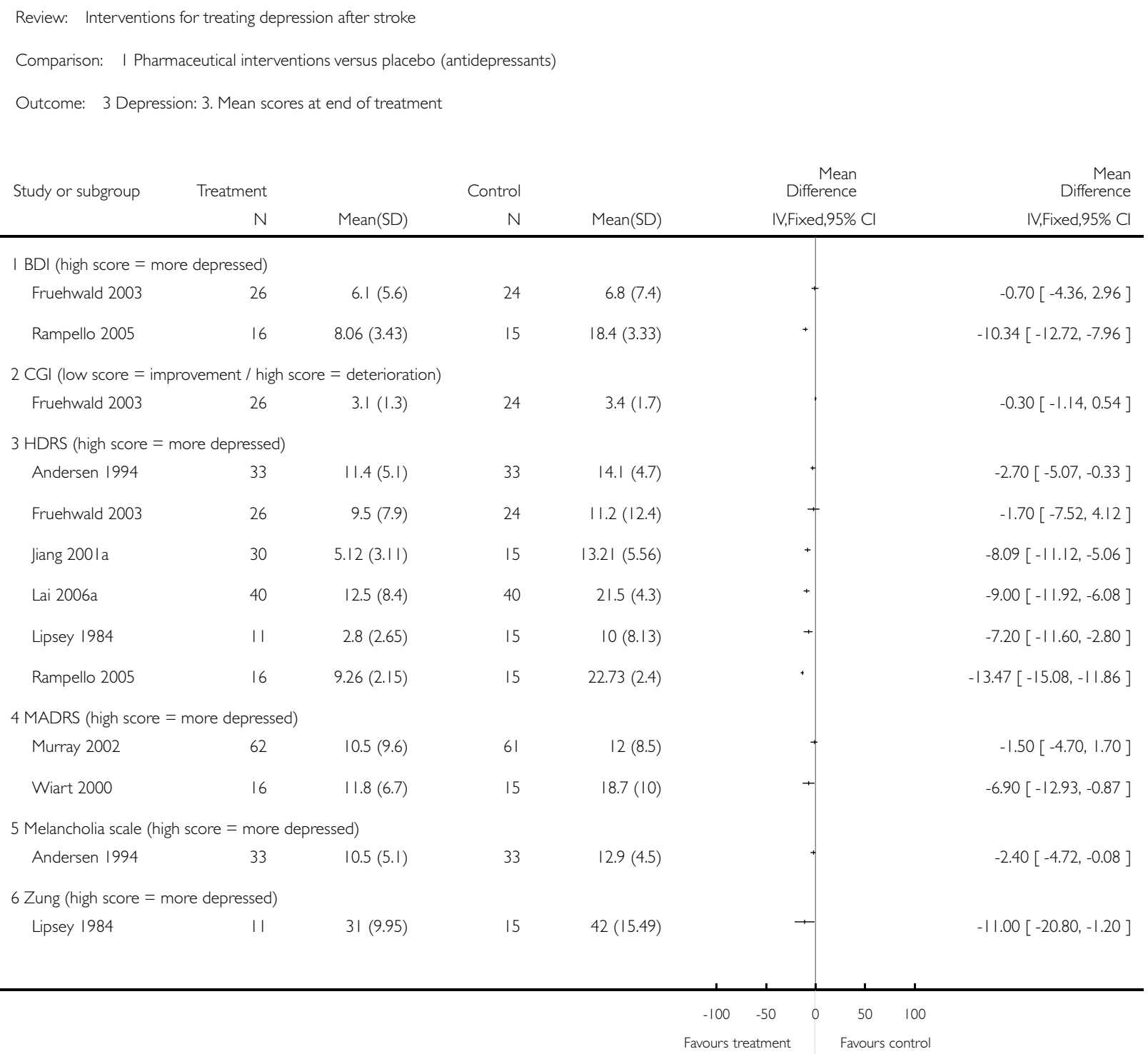


Analysis I.4. Comparison I Pharmaceutical interventions versus placebo (antidepressants), Outcome 4 Depression: 4 . Less than $\mathbf{5 0 \%}$ reduction in scale scores.

Review: Interventions for treating depression after stroke

Comparison: I Pharmaceutical interventions versus placebo (antidepressants)

Outcome: 4 Depression: 4 . Less than $50 \%$ reduction in scale scores

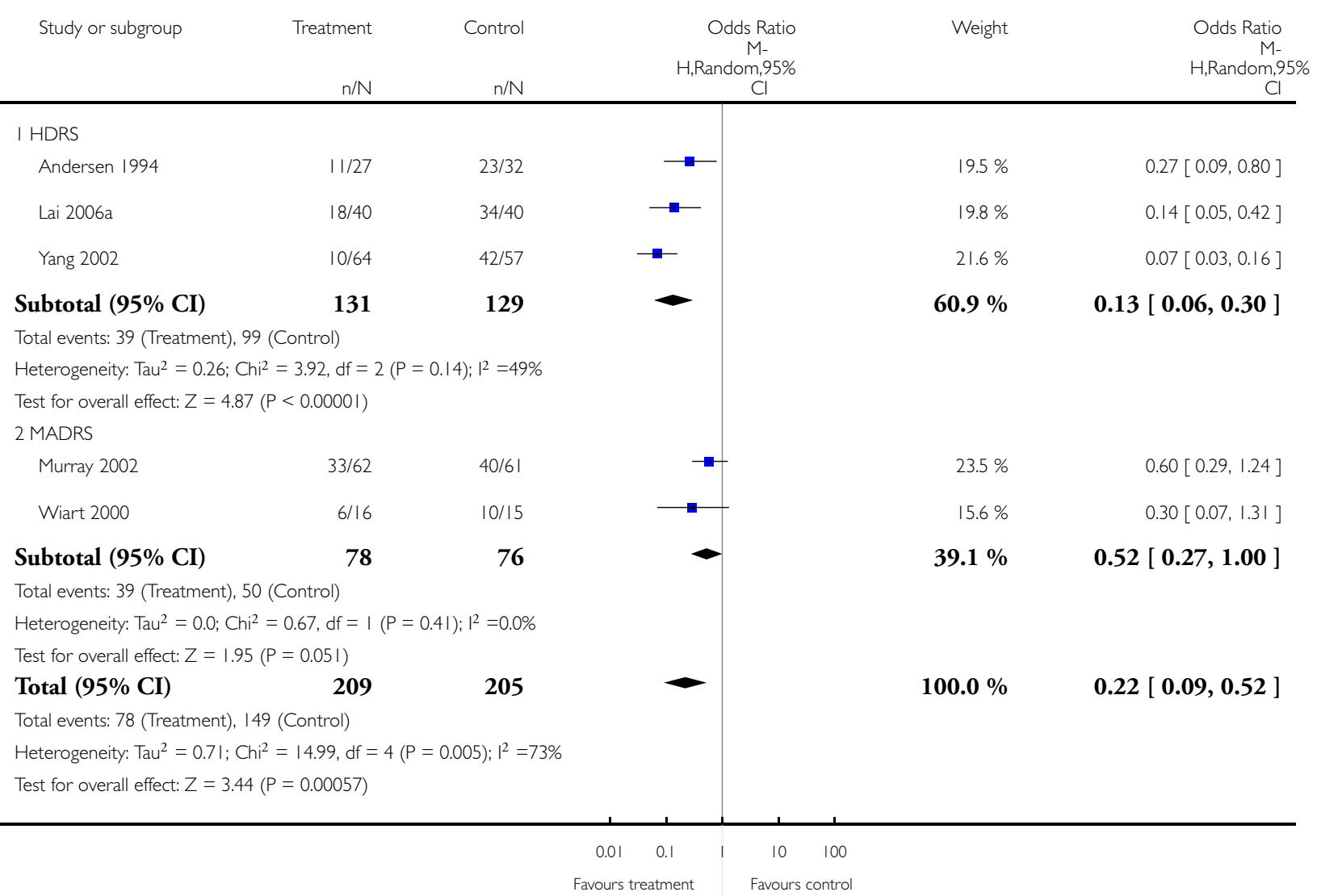


Analysis I.5. Comparison I Pharmaceutical interventions versus placebo (antidepressants), Outcome 5 Anxiety: I. Meeting study criteria for anxiety.

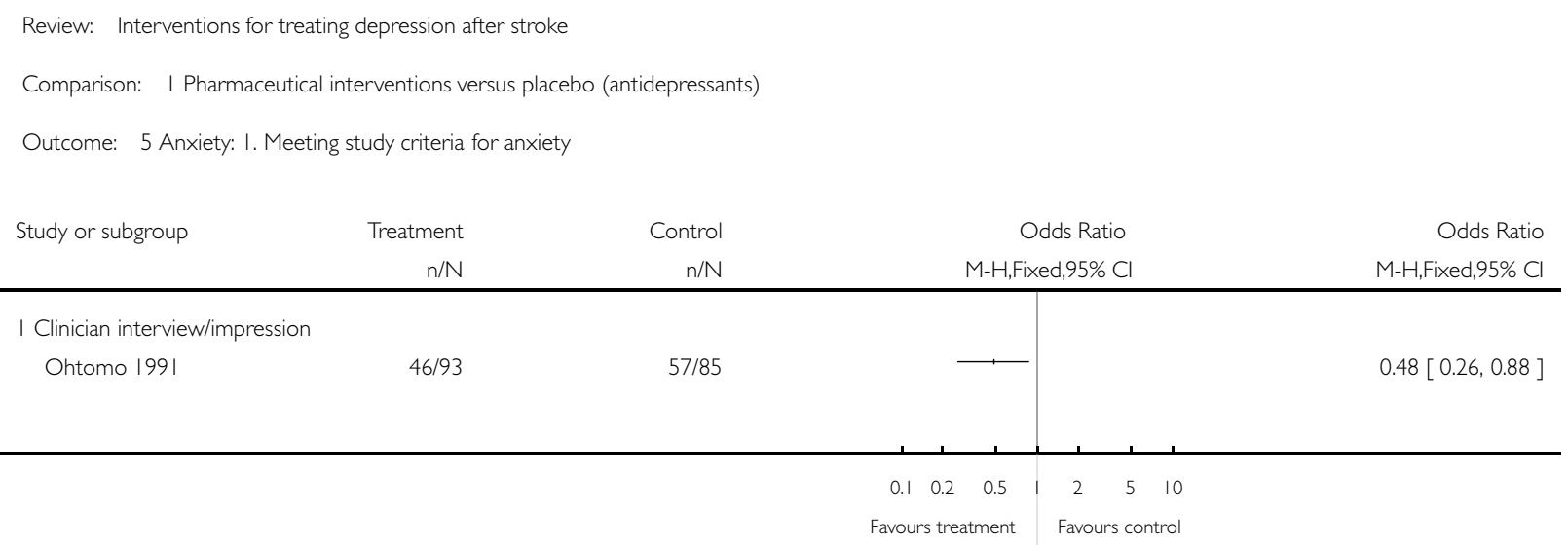

Analysis I.6. Comparison I Pharmaceutical interventions versus placebo (antidepressants), Outcome 6 Cognitive functioning: I. Average change in scores between baseline and end of treatment.

Review: Interventions for treating depression after stroke

Comparison: I Pharmaceutical interventions versus placebo (antidepressants)

Outcome: 6 Cognitive functioning: I. Average change in scores between baseline and end of treatment

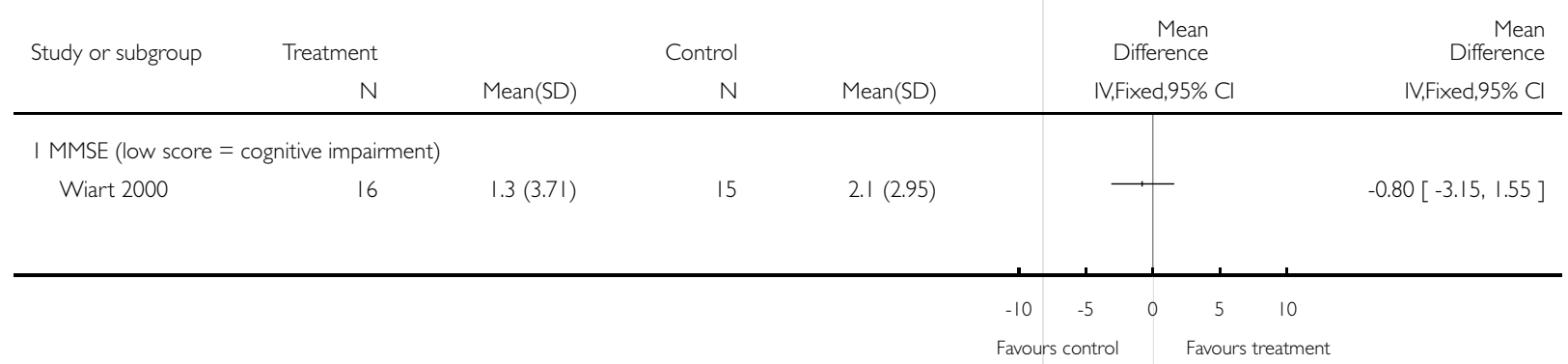


Analysis I.7. Comparison I Pharmaceutical interventions versus placebo (antidepressants), Outcome 7 Cognitive functioning: 2 . Mean scores at end of treatment.

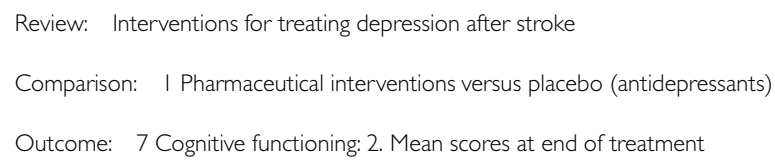

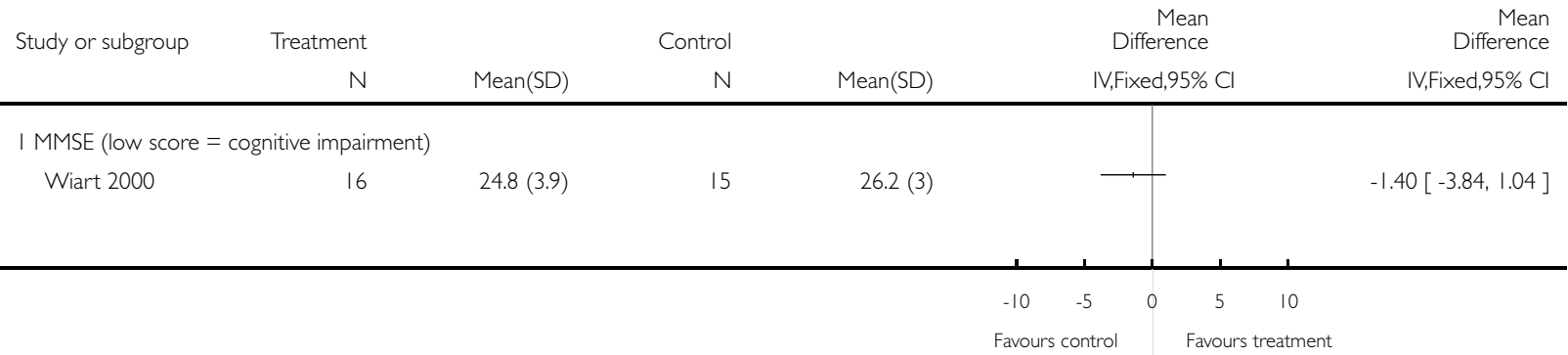

Analysis I.8. Comparison I Pharmaceutical interventions versus placebo (antidepressants), Outcome 8 Activities of daily living: I. Average change in scores between baseline and end of treatment.

Review: Interventions for treating depression after stroke

Comparison: I Pharmaceutical interventions versus placebo (antidepressants)

Outcome: 8 Activities of daily living: I. Average change in scores between baseline and end of treatment

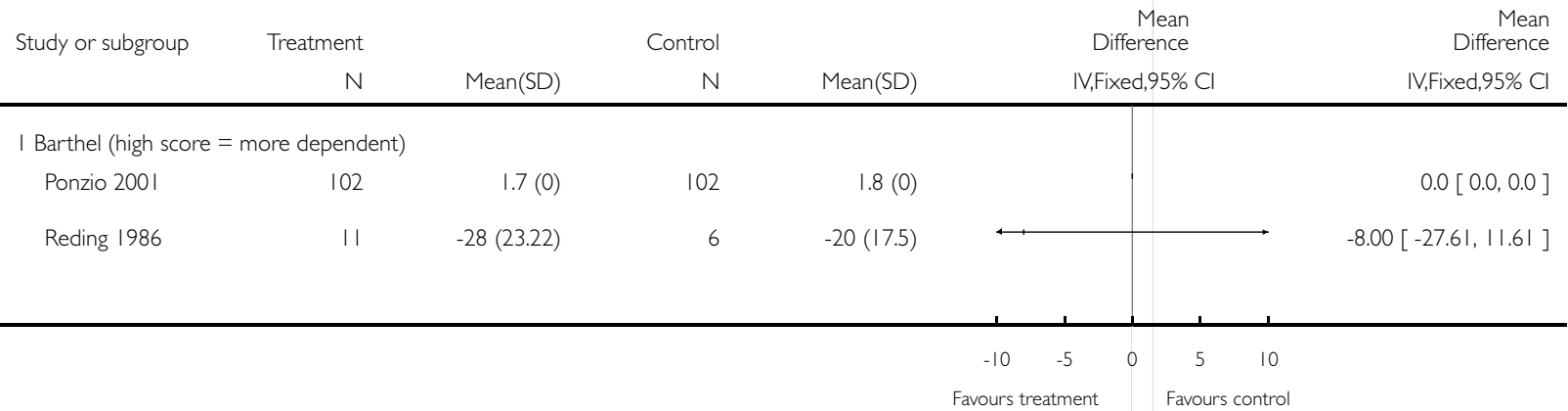


Analysis I.9. Comparison I Pharmaceutical interventions versus placebo (antidepressants), Outcome 9 Disability: I. Average change in scores between baseline and end of treatment.

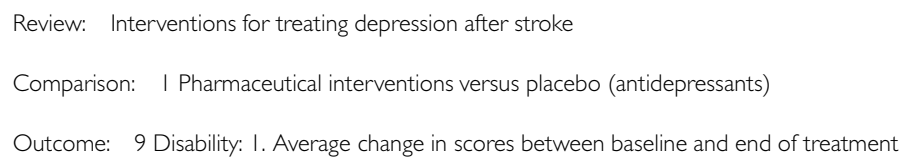

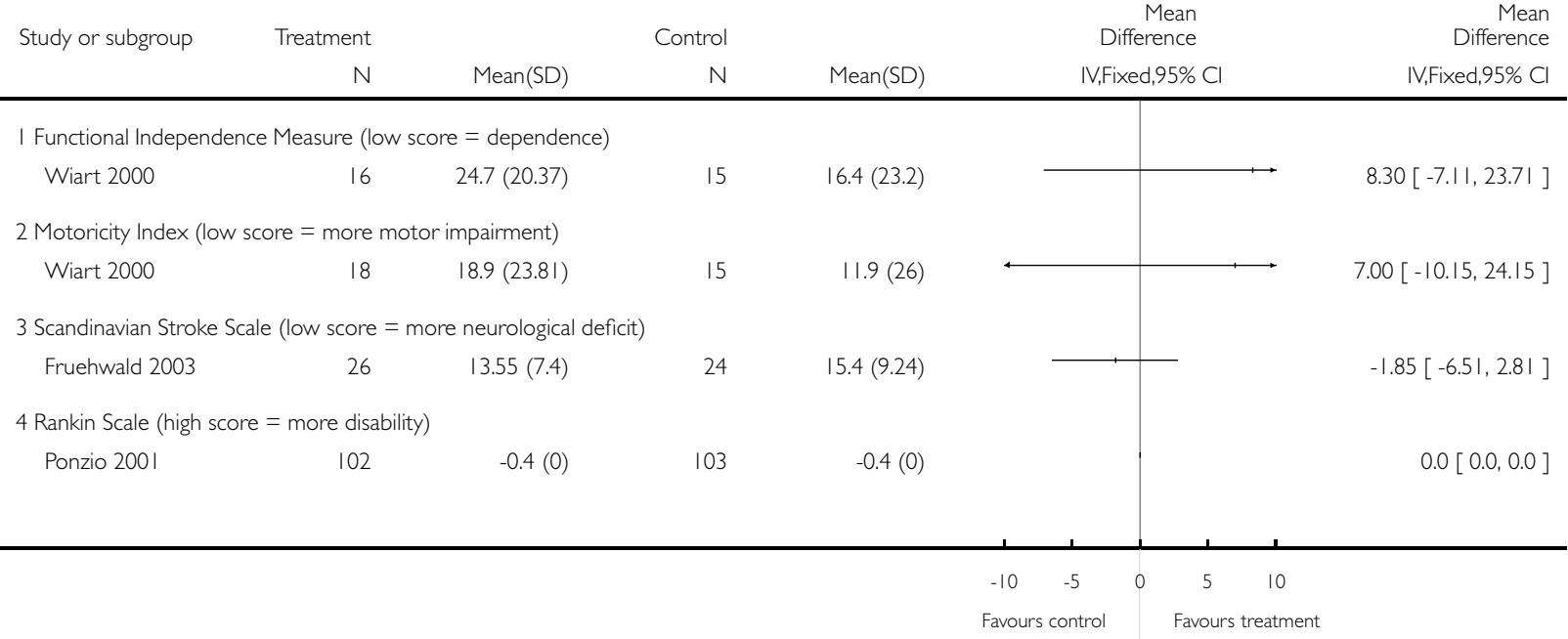

\section{Analysis I.10. Comparison I Pharmaceutical interventions versus placebo (antidepressants), Outcome I0} Disability: 2. Mean scores at end of treatment.

Review: Interventions for treating depression after stroke

Comparison: I Pharmaceutical interventions versus placebo (antidepressants)

Outcome: 10 Disability: 2. Mean scores at end of treatment

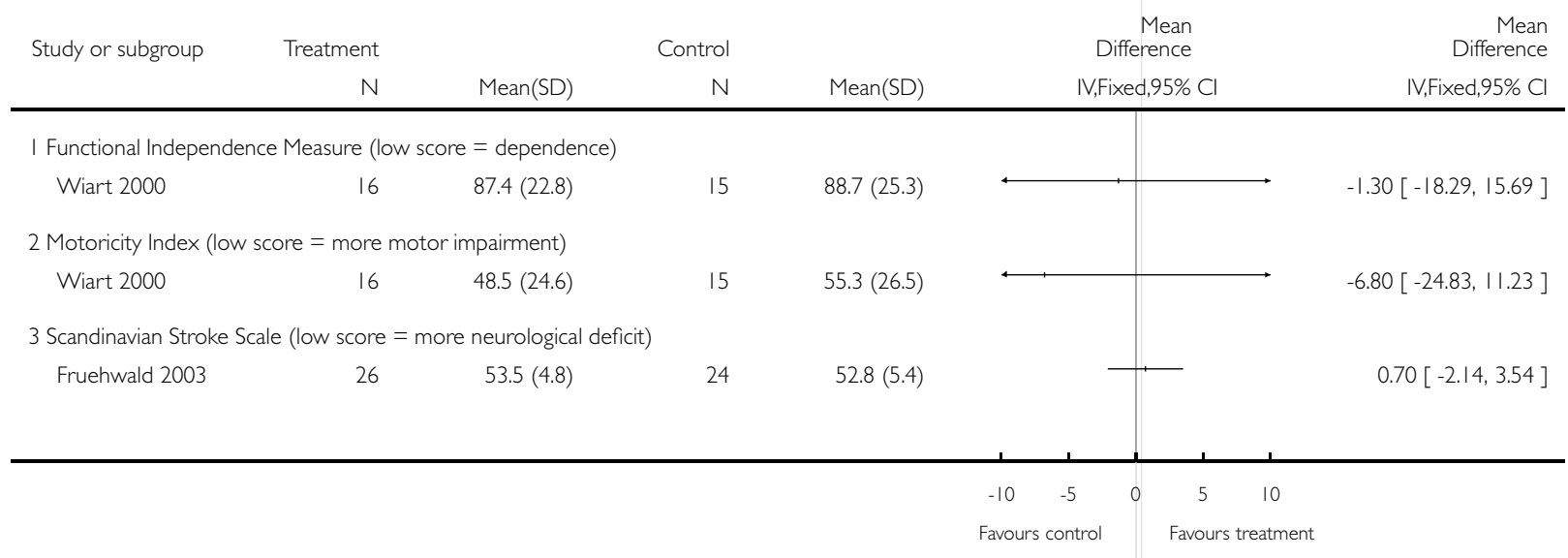




\section{Analysis I.II. Comparison I Pharmaceutical interventions versus placebo (antidepressants), Outcome II}

Neurological function: I. Average change in scores between baseline and end of treatment.

Review: Interventions for treating depression after stroke

Comparison: I Pharmaceutical interventions versus placebo (antidepressants)

Outcome: II Neurological function: I. Average change in scores between baseline and end of treatment

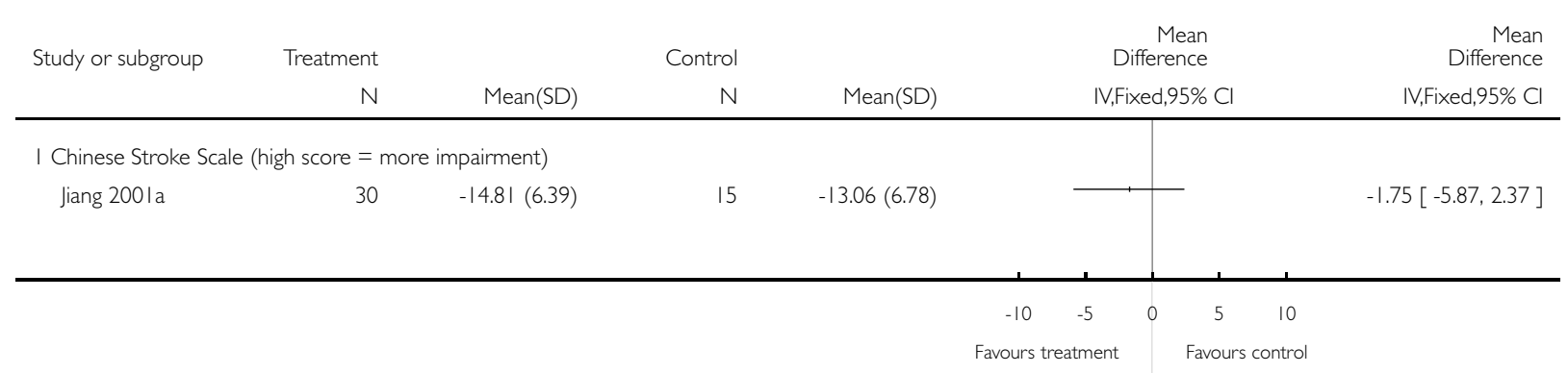

Analysis I.12. Comparison I Pharmaceutical interventions versus placebo (antidepressants), Outcome I2 Neurological function: 2 . Mean scores at end of treatment.

Review: Interventions for treating depression after stroke

Comparison: I Pharmaceutical interventions versus placebo (antidepressants)

Outcome: 12 Neurological function: 2. Mean scores at end of treatment

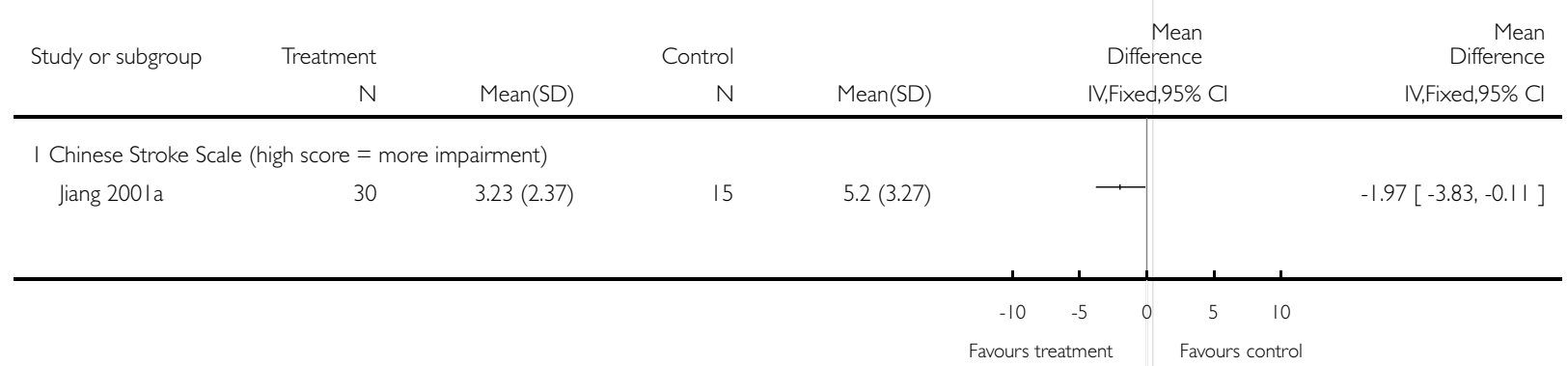


Analysis I.13. Comparison I Pharmaceutical interventions versus placebo (antidepressants), Outcome I3 Adverse events: I. Death.

Review: Interventions for treating depression after stroke

Comparison: I Pharmaceutical interventions versus placebo (antidepressants)

Outcome: 13 Adverse events: I. Death

\begin{tabular}{|c|c|c|c|c|}
\hline \multirow[t]{2}{*}{ Study or subgroup } & \multirow{2}{*}{$\begin{array}{r}\text { Treatment } \\
\mathrm{n} / \mathrm{N}\end{array}$} & \multirow{2}{*}{$\begin{array}{r}\text { Control } \\
n / N\end{array}$} & Odds Ratio & \multirow{2}{*}{$\begin{array}{r}\text { Odds Ratio } \\
\text { M-H,Fixed,95\% Cl }\end{array}$} \\
\hline & & & M-H,Fixed,95\% Cl & \\
\hline \multicolumn{5}{|l|}{ I At end of treatment } \\
\hline Andersen 1994 & $1 / 33$ & $1 / 33$ & & $1.00[0.06,16.69]$ \\
\hline Fruehwald 2003 & $1 / 28$ & $0 / 26$ & & $2.89[0.11,74.17]$ \\
\hline Lipsey 1984 & $0 / 14$ & $2 / 20$ & $\longleftarrow$ & $0.26[0.01,5.74]$ \\
\hline Murray 2002 & $0 / 62$ & $2 / 61$ & $\longleftarrow$ & $0.19[0.01,4.05]$ \\
\hline Ponzio 200। & $0 / 112$ & $0 / 117$ & & $0.0[0.0,0.0]$ \\
\hline Wiart 2000 & $0 / 16$ & $0 / 15$ & & $0.0[0.0,0.0]$ \\
\hline Subtotal $(95 \% \mathrm{CI})$ & 265 & 272 & & $0.57[0.15,2.15]$ \\
\hline \multicolumn{5}{|c|}{ Total events: 2 (Treatment), 5 (Control) } \\
\hline \multicolumn{5}{|c|}{ Heterogeneity: Chi $^{2}=1.87, d f=3(P=0.60) ;\left.\right|^{2}=0.0 \%$} \\
\hline \multicolumn{5}{|c|}{ Test for overall effect: $Z=0.84(P=0.40)$} \\
\hline
\end{tabular}


Analysis I.I4. Comparison I Pharmaceutical interventions versus placebo (antidepressants), Outcome I4 Adverse events: 2. All.

Review: Interventions for treating depression after stroke

Comparison: I Pharmaceutical interventions versus placebo (antidepressants)

Outcome: 14 Adverse events: 2. All

$\begin{array}{lllll}\text { Study or subgroup } & \text { Treatment } & \text { Control } & \text { Odds Ratio } & \text { Weight }\end{array}$

$n / N \quad n / N$

I Central nervous system events (e.g. confusion, sedation, tremor)

Andersen $1994 \quad 2 / 33 \quad 0 / 33$

Lipsey $1984 \quad 4 / 17 \quad 0 / 22$

$\begin{array}{lll}\text { Murray } 2002 \quad 33 / 62 & 28 / 61\end{array}$

$\begin{array}{lll}\text { Ponzio } 2001 \quad 17 / 112 & 8 / 117\end{array}$

Wiart 2000

$3 / 16 \quad 2 / 15$

Subtotal (95\% CI)

240

248

Total events: 59 (Treatment), 38 (Control)

Heterogeneity: $\mathrm{Chi}^{2}=3.58, \mathrm{df}=4(\mathrm{P}=0.47) ; \mathrm{I}^{2}=0.0 \%$

Test for overall effect: $Z=2.64(P=0.0084)$

2 Gastrointestinal effects (e.g. constipation, diarrhoea)

$\begin{array}{lrr}\text { Murray } 2002 & 44 / 62 & 27 / 61 \\ \text { Ponzio 2001 } & 17 / 112 & 8 / 117 \\ & & \\ & 1 / 16 & 3 / 15\end{array}$

Wiart 2000

190

193

Total events: 62 (Treatment), 38 (Control)

Heterogeneity: $\mathrm{Chi}^{2}=3.70, \mathrm{df}=2(\mathrm{P}=0.16) ; 1^{2}=46 \%$

Test for overall effect: $Z=3.12(P=0.0018)$

3 Other events - not listed above (e.g. dysuria, eye discomfort)

$\begin{array}{lcc}\text { Andersen 1994 } & \text { 1/33 } & 0 / 3 \\ \text { Fruehwald 2003 } & 0 / 26 & 1 / 2 \\ \text { Jiang 200 Ia } & 2 / 30 & 0 / 15 \\ \text { Murray 2002 } & 37 / 62 & 26 / 6 \\ \text { Ponzio 2001 } & 29 / 112 & 26 / 11 \\ \text { Wiart 2000 } & 1 / 16 & 0 / 15\end{array}$

Subtotal (95\% CI)

279

265

:

48

Total events: 70 (Treatment), 53 (Control)

Heterogeneity: $\mathrm{Chi}^{2}=2.50, \mathrm{df}=5(\mathrm{P}=0.78) ; \mathrm{I}^{2}=0.0 \%$

Test for overall effect: $Z=1.84(P=0.066)$

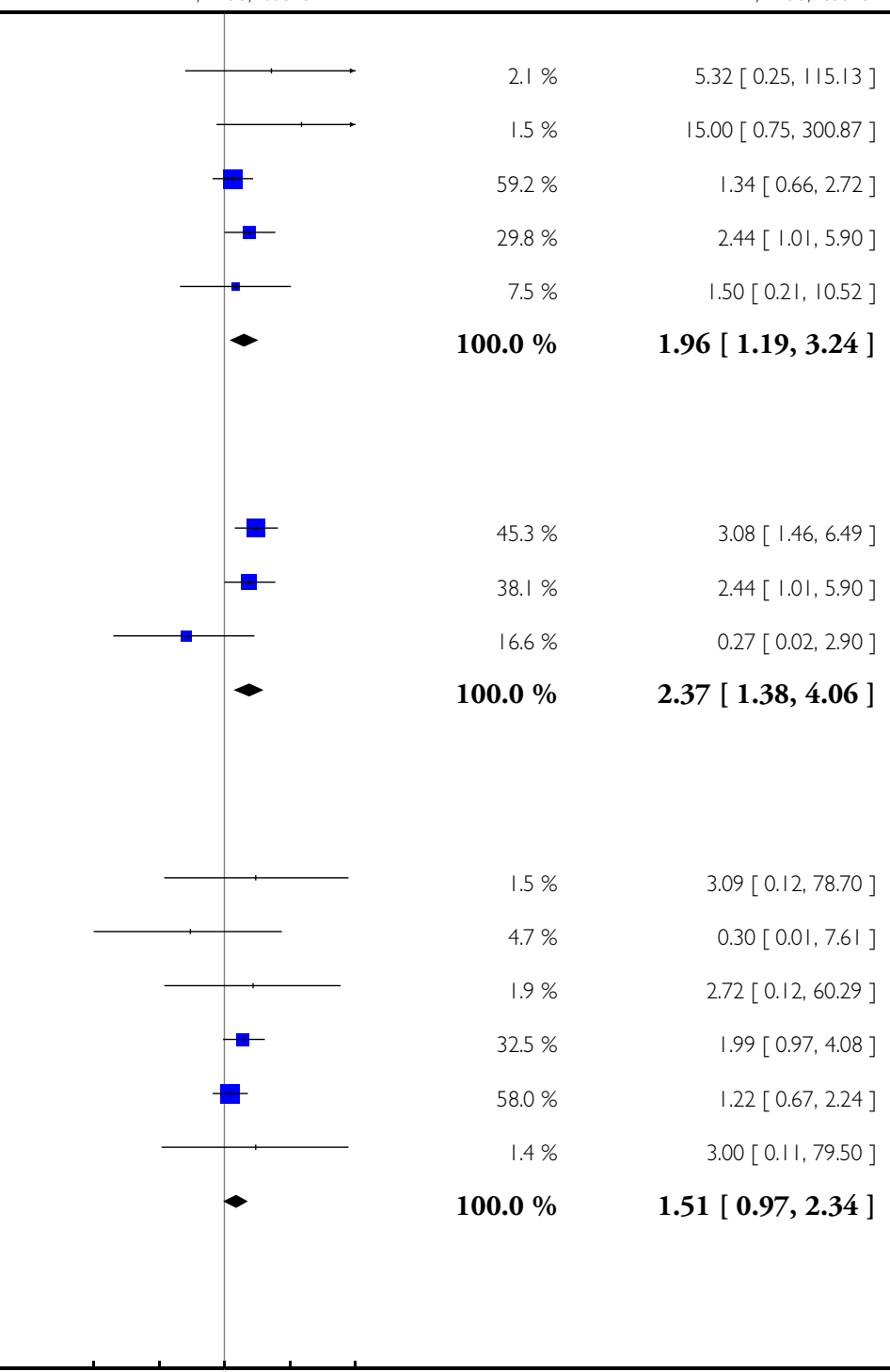

$5.32[0.25,115.13]$

2

7




\begin{tabular}{|c|c|c|c|c|c|}
\hline Study or subgroup & $\begin{array}{r}\text { Treatment } \\
\mathrm{n} / \mathrm{N}\end{array}$ & $\begin{array}{r}\text { Control } \\
\mathrm{n} / \mathrm{N} \\
\end{array}$ & $\begin{array}{c}\text { Odds Ratio } \\
\text { M-H,Fixed,95\% Cl }\end{array}$ & Weight & $\begin{array}{c}\text { (... Continued) } \\
\text { Odds Ratio } \\
\text { M-H,Fixed,95\% Cl }\end{array}$ \\
\hline \multicolumn{6}{|c|}{4 Protocol violation (e.g. refused treatment, withdrew consent) } \\
\hline Andersen 1994 & $1 / 33$ & $0 / 33$ & & $12.1 \%$ & $3.09[0.12,78.70]$ \\
\hline Lipsey 1984 & $0 / 17$ & 3/22 & 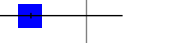 & $75.9 \%$ & $0.16[0.01,3.30]$ \\
\hline Wiart 2000 & $1 / 16$ & $0 / 15$ & - & $11.9 \%$ & $3.00[0.11,79.50]$ \\
\hline Subtotal $(95 \% \mathrm{CI})$ & 66 & 70 & - & $100.0 \%$ & $0.85[0.20,3.66]$ \\
\hline \multicolumn{6}{|c|}{ Total events: 2 (Treatment), 3 (Control) } \\
\hline \multicolumn{6}{|c|}{ Heterogeneity: $\mathrm{Chi}^{2}=2.35, \mathrm{df}=2(P=0.31) ; 1^{2}=15 \%$} \\
\hline \multicolumn{6}{|c|}{ Test for overall effect: $Z=0.21 \quad(P=0.83)$} \\
\hline \multicolumn{6}{|c|}{5 Psychiatric events (e.g. anxiety, increased depression) } \\
\hline Fruehwald 2003 & $0 / 26$ & 1/24 & = & $54.4 \%$ & $0.30[0.01,7.61]$ \\
\hline Lipsey 1984 & $0 / 17$ & 1/22 & \# & $45.6 \%$ & $0.41[0.02,10.69]$ \\
\hline Subtotal (95\% CI) & 43 & 46 & & $100.0 \%$ & $0.35[0.03,3.47]$ \\
\hline \multicolumn{6}{|c|}{ Total events: 0 (Treatment), 2 (Control) } \\
\hline \multicolumn{6}{|c|}{ Heterogeneity: Chi $^{2}=0.02, d f=|(P=0.89) ;|^{2}=0.0 \%$} \\
\hline \multicolumn{6}{|c|}{ Test for overall effect: $Z=0.90(P=0.37)$} \\
\hline \multicolumn{6}{|l|}{6 Recurrent stroke } \\
\hline Andersen 1994 & 1/33 & 0/33 & & $27.2 \%$ & $3.09[0.12,78.70]$ \\
\hline Lipsey 1984 & $0 / 17$ & 1/22 & a & $72.8 \%$ & $0.41[0.02,10.69]$ \\
\hline Subtotal $(95 \% \mathrm{CI})$ & 50 & 55 & & $100.0 \%$ & $1.14[0.15,8.60]$ \\
\hline \multicolumn{6}{|c|}{ Total events: I (Treatment), I (Control) } \\
\hline \multicolumn{6}{|c|}{ Heterogeneity: $\mathrm{Ch}^{2}=0.74, \mathrm{df}=\mathrm{I}(\mathrm{P}=0.39) ; \mathrm{I}^{2}=0.0 \%$} \\
\hline \multicolumn{6}{|c|}{ Test for overall effect: $Z=0.13(P=0.90)$} \\
\hline \multicolumn{6}{|c|}{7 Vascular events - not stroke (e.g. dizziness, palpitation) } \\
\hline Andersen 1994 & 1/33 & 1/33 & & $4.5 \%$ & $1.00[0.06,16.69]$ \\
\hline Fruehwald 2003 & 1/26 & 0/24 & & $2.3 \%$ & $2.88[0.11,74.21]$ \\
\hline Jiang $200 \mathrm{la}$ & $7 / 30$ & $0 / 15$ & & $2.3 \%$ & $9.89[0.53,185.97]$ \\
\hline Lipsey 1984 & $2 / 17$ & $1 / 22$ & & $3.6 \%$ & $2.80[0.23,33.78]$ \\
\hline Murray 2002 & $22 / 62$ & $|8 / 6|$ & + & $54.9 \%$ & $1.31[0.62,2.80]$ \\
\hline Ponzio 2001 & $9 / 112$ & $6 / 117$ & - & $25.3 \%$ & $1.62[0.56,4.70]$ \\
\hline Wiart 2000 & $0 / 16$ & $1 / 15$ & & $7.0 \%$ & $0.29[0.01,7.76]$ \\
\hline Subtotal $(95 \% \mathrm{CI})$ & 296 & 287 & - & $100.0 \%$ & $1.60[0.93,2.73]$ \\
\hline \multicolumn{6}{|c|}{ Total events: 42 (Treatment), 27 (Control) } \\
\hline \multicolumn{6}{|c|}{ Heterogeneity: $\mathrm{Chi}^{2}=3.20, \mathrm{df}=6(P=0.78) ; \mathrm{I}^{2}=0.0 \%$} \\
\hline Test for overall effect: $Z=$ & $=0.089)$ & & & & \\
\hline
\end{tabular}


Analysis I.I5. Comparison I Pharmaceutical interventions versus placebo (antidepressants), Outcome I5 Adverse events: 3 . Leaving the study early (including death).

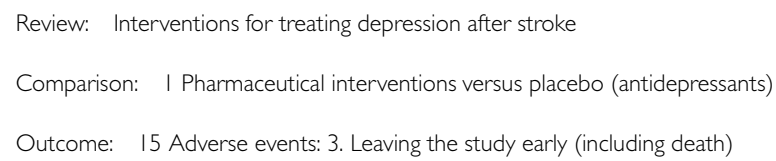

$n / \mathrm{N} \quad \mathrm{n} / \mathrm{N}-\mathrm{M}-\mathrm{H}$, Fixed,95\% Cl M-H,Fixed,95\% Cl

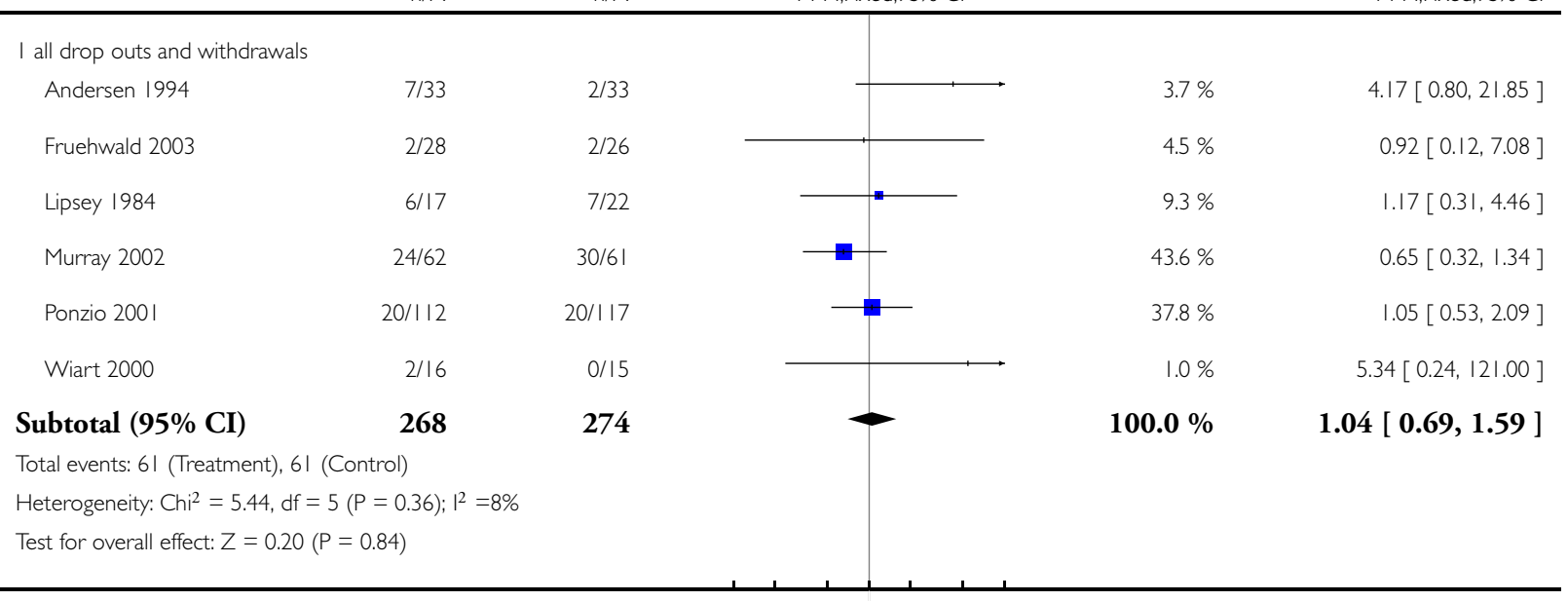

Analysis 2.I. Comparison 2 Pharmaceutical interventions versus placebo (combination therapy), Outcome I Depression: I. Average change in scores between baseline and end of treatment.

Review: Interventions for treating depression after stroke

Comparison: 2 Pharmaceutical interventions versus placebo (combination therapy)

Outcome: I Depression: I. Average change in scores between baseline and end of treatment

\begin{tabular}{|c|c|c|c|c|c|c|c|c|c|c|}
\hline \multirow[t]{2}{*}{ Study or subgroup } & \multirow{2}{*}{$\begin{array}{r}\text { Treatment } \\
N\end{array}$} & \multicolumn{3}{|c|}{ Control } & \multicolumn{5}{|c|}{$\begin{array}{r}\text { Mean } \\
\text { Difference }\end{array}$} & \multirow{2}{*}{$\begin{array}{r}\text { Mean } \\
\text { Difference } \\
\text { IV,Fixed,95\% Cl }\end{array}$} \\
\hline & & Mean(SD) & $\mathrm{N}$ & Mean(SD) & \multicolumn{5}{|c|}{ IV,Fixed,95\% Cl } & \\
\hline \multicolumn{11}{|c|}{ I HDRS (high score = more depressed) } \\
\hline \multirow[t]{3}{*}{ Jiang $200 \mathrm{lb}$} & 30 & $-19.94(6.66)$ & 15 & $-11.85(7.5)$ & $\leftarrow$ & 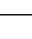 & & & & $-8.09[-|2.57,-3.6|]$ \\
\hline & & & & & -10 & -5 & 0 & 5 & 10 & \\
\hline & & & & & Favours & tme & & Favours & ontrol & \\
\hline
\end{tabular}


Analysis 2.2. Comparison 2 Pharmaceutical interventions versus placebo (combination therapy), Outcome 2 Depression: 2. Mean scores at end of treatment.

Review: Interventions for treating depression after stroke

Comparison: 2 Pharmaceutical interventions versus placebo (combination therapy)

Outcome: 2 Depression: 2. Mean scores at end of treatment

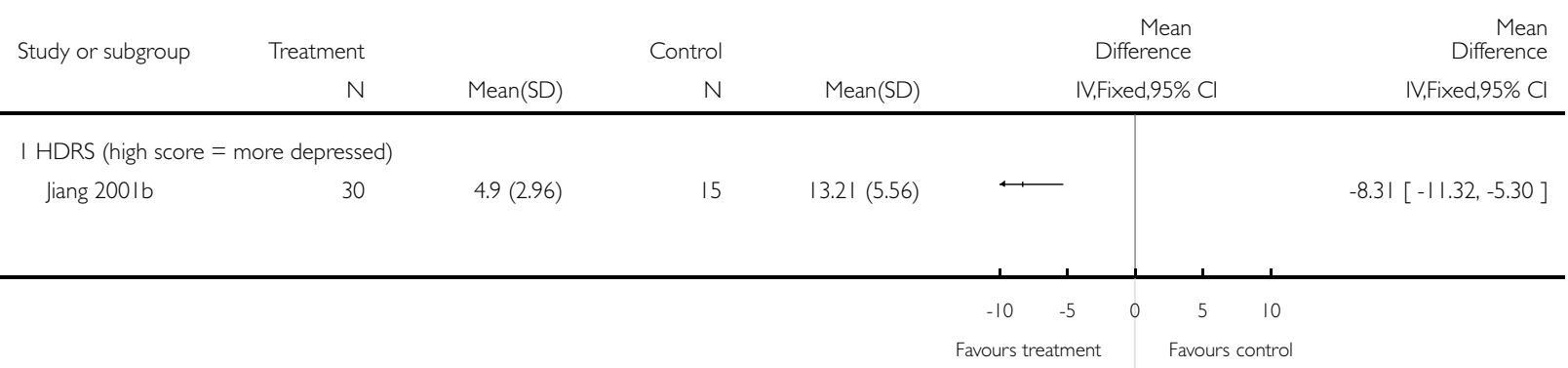

Analysis 2.3. Comparison 2 Pharmaceutical interventions versus placebo (combination therapy), Outcome 3 Neurological function: I. Average change in scores between baseline and end of treatment.

Review: Interventions for treating depression after stroke

Comparison: 2 Pharmaceutical interventions versus placebo (combination therapy)

Outcome: 3 Neurological function: 1. Average change in scores between baseline and end of treatment

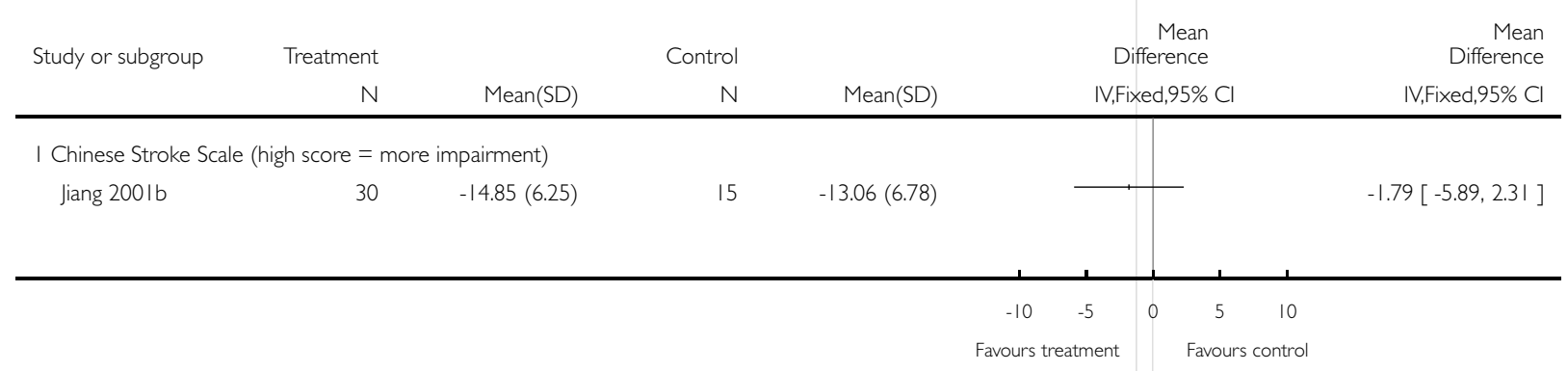


Analysis 2.4. Comparison 2 Pharmaceutical interventions versus placebo (combination therapy), Outcome 4 Neurological function: 2 . Mean scores at end of treatment.

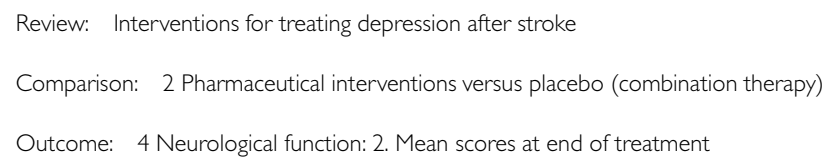

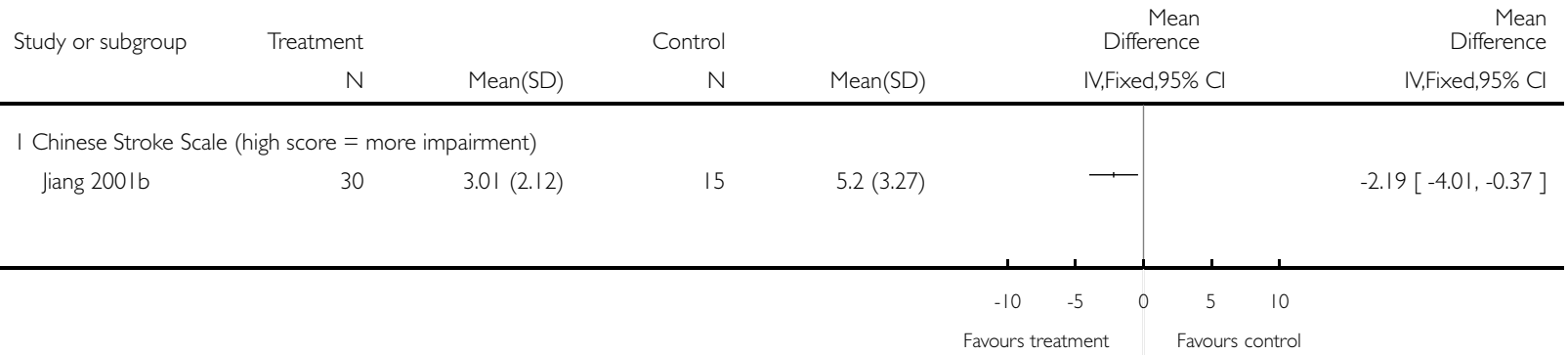

Analysis 2.5. Comparison 2 Pharmaceutical interventions versus placebo (combination therapy), Outcome 5 Adverse events: I. All.

Review: Interventions for treating depression after stroke

Comparison: 2 Pharmaceutical interventions versus placebo (combination therapy)

Outcome: 5 Adverse events: I. All

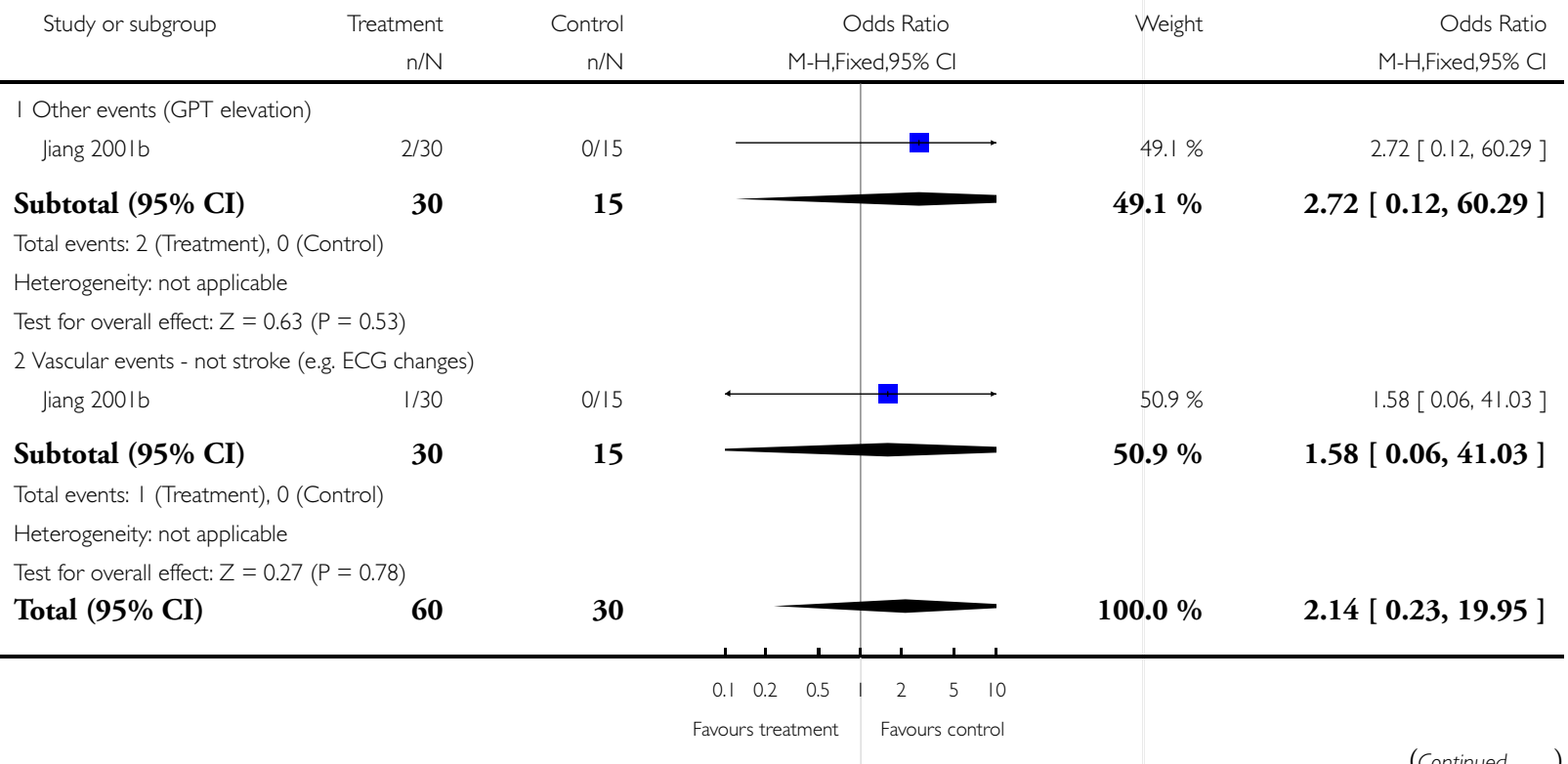




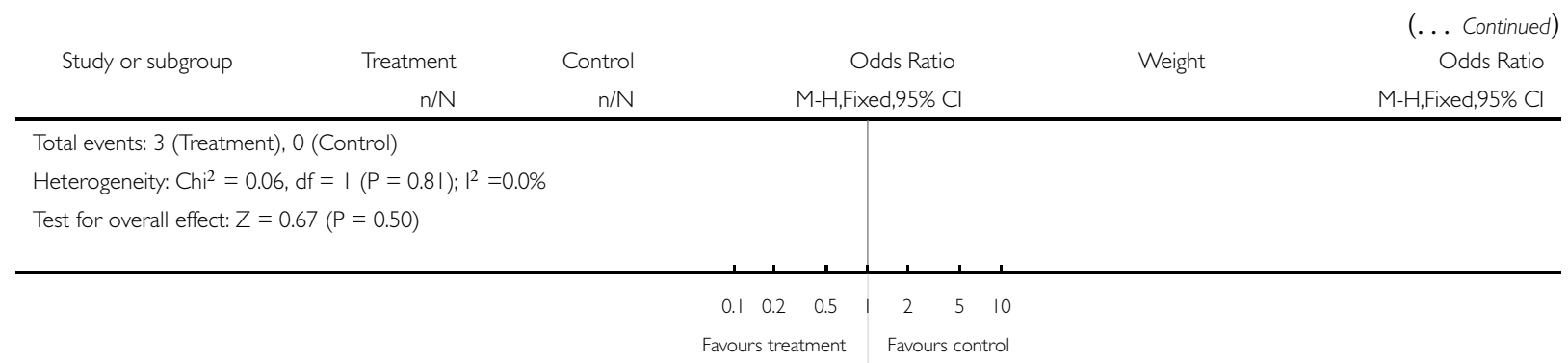

Analysis 3.1. Comparison 3 Psychological interventions versus standard care and/or attention control, Outcome I Depression: Meeting study criteria for depression at end of treatment.

Review: Interventions for treating depression after stroke

Comparison: 3 Psychological interventions versus standard care and/or attention control

Outcome: I Depression: Meeting study criteria for depression at end of treatment

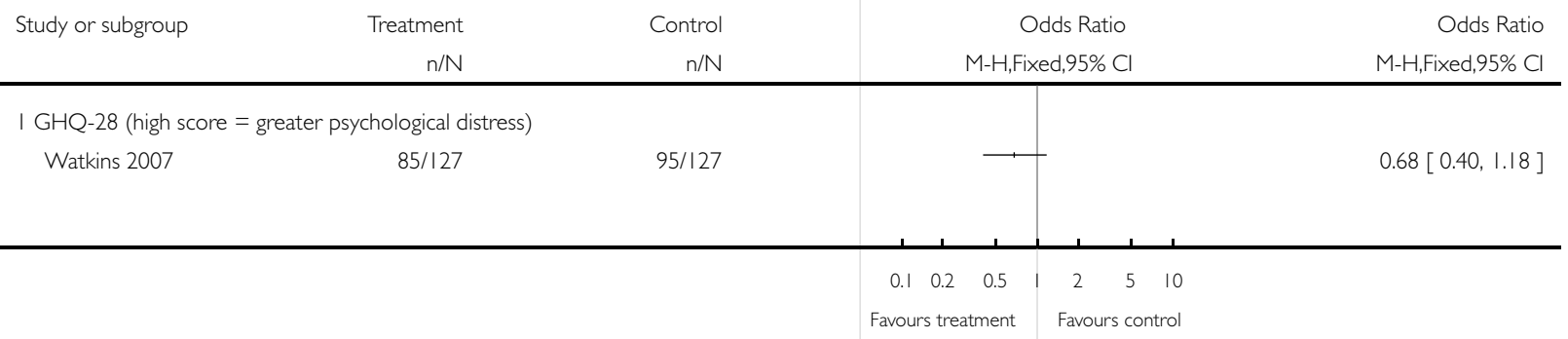


Analysis 3.2. Comparison 3 Psychological interventions versus standard care and/or attention control, Outcome 2 Depression: I. Average change in scores between baseline and end of treatment.

Review: Interventions for treating depression after stroke

Comparison: 3 Psychological interventions versus standard care and/or attention control

Outcome: 2 Depression: I. Average change in scores between baseline and end of treatment

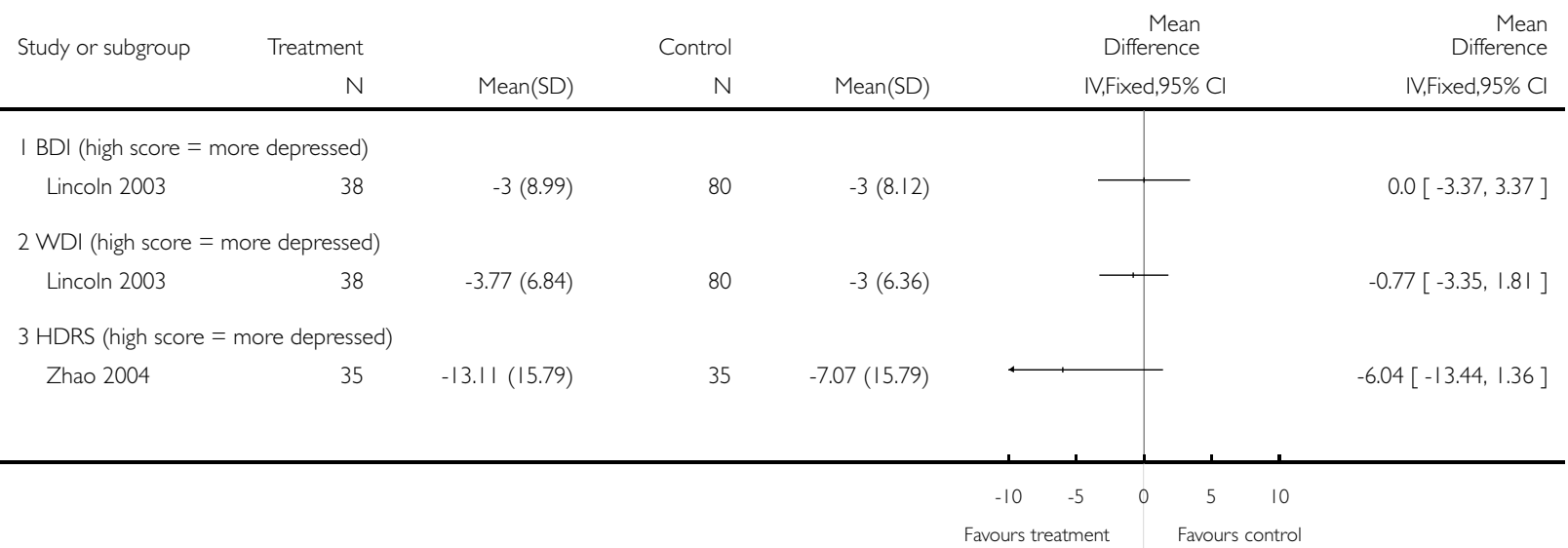

Analysis 3.3. Comparison 3 Psychological interventions versus standard care and/or attention control, Outcome 3 Depression: 2. Mean scores at end of treatment.

Review: Interventions for treating depression after stroke

Comparison: 3 Psychological interventions versus standard care and/or attention control

Outcome: 3 Depression: 2. Mean scores at end of treatment

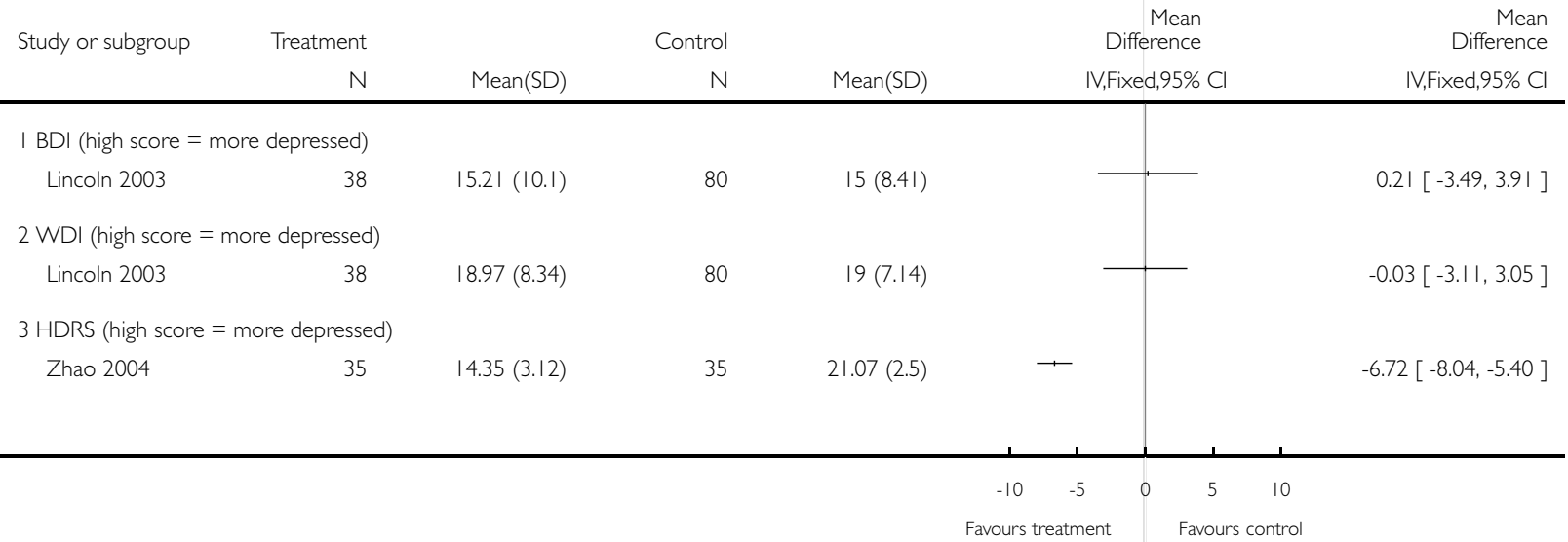


Analysis 3.4. Comparison 3 Psychological interventions versus standard care and/or attention control, Outcome 4 Psychological distress: I. Average change in scores between baseline and end of treatment.

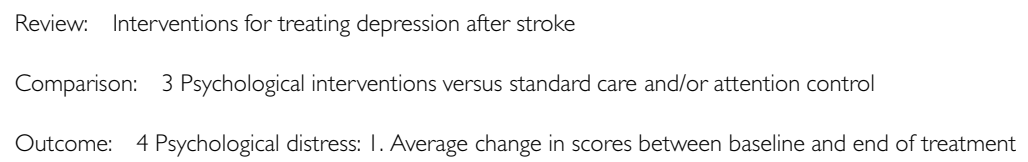

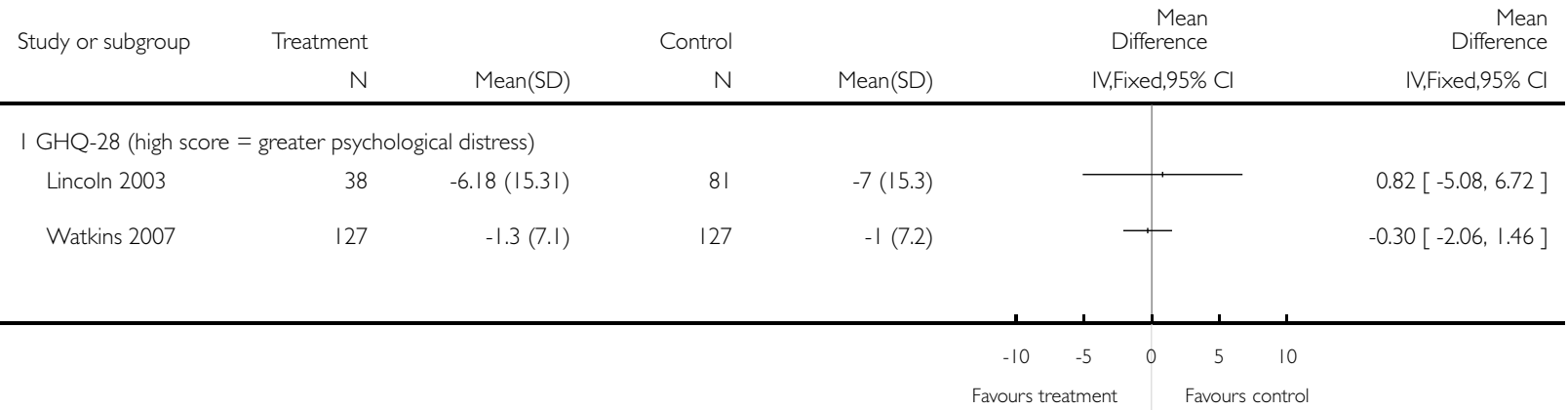

Analysis 3.5. Comparison 3 Psychological interventions versus standard care and/or attention control, Outcome 5 Psychological distress: 2. Mean scores at end of treatment.

Review: Interventions for treating depression after stroke

Comparison: 3 Psychological interventions versus standard care and/or attention control

Outcome: 5 Psychological distress: 2. Mean scores at end of treatment

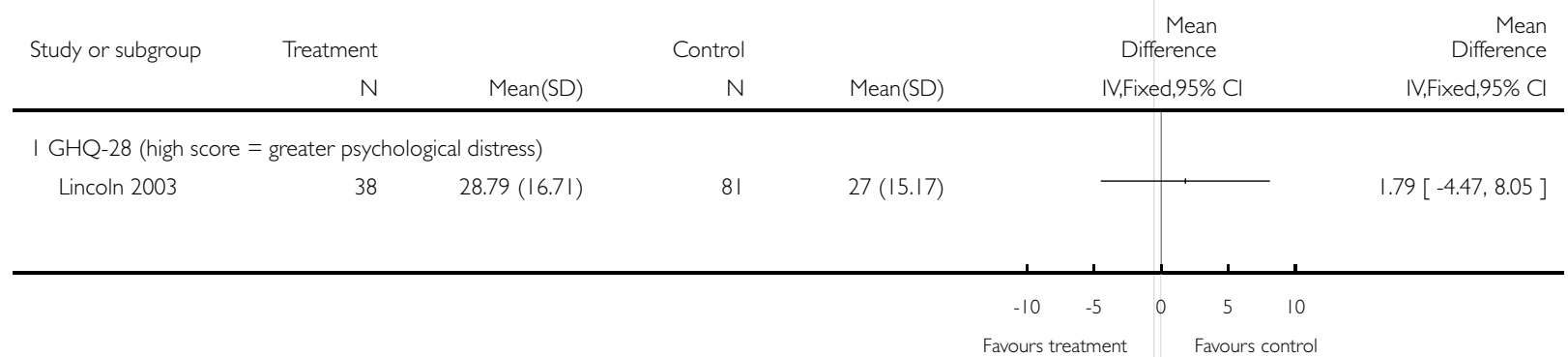


Analysis 3.6. Comparison 3 Psychological interventions versus standard care and/or attention control, Outcome 6 Activities of daily living: I. Average change in scores from baseline to end of treatment.

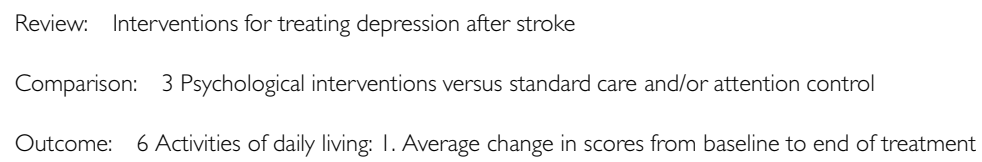

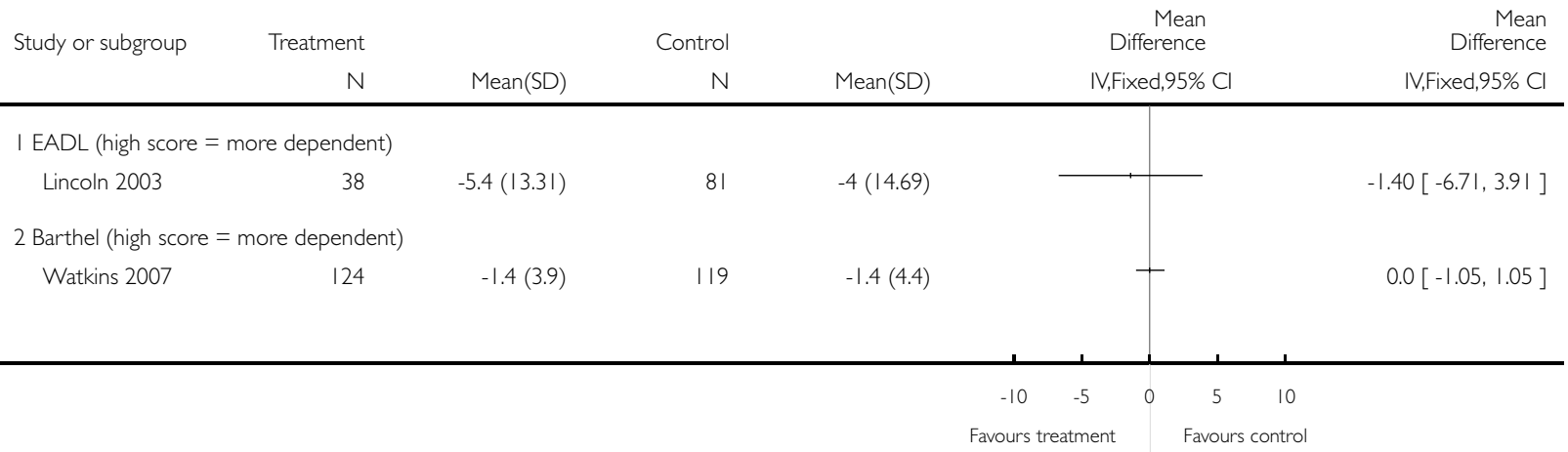

Analysis 3.7. Comparison 3 Psychological interventions versus standard care and/or attention control, Outcome 7 Activities of daily living: 2. Mean scores at end of treatment.

Review: Interventions for treating depression after stroke

Comparison: 3 Psychological interventions versus standard care and/or attention control

Outcome: 7 Activities of daily living: 2. Mean scores at end of treatment

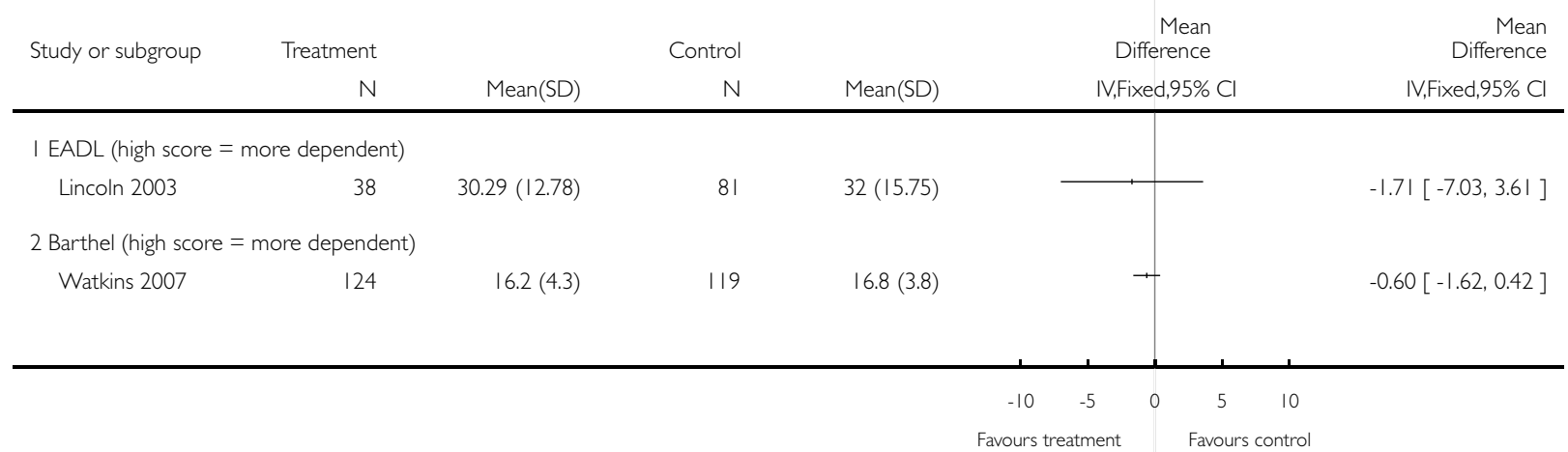


Analysis 3.8. Comparison 3 Psychological interventions versus standard care and/or attention control, Outcome 8 Adverse events: I. Death.

Review: Interventions for treating depression after stroke

Comparison: 3 Psychological interventions versus standard care and/or attention control

Outcome: 8 Adverse events: I. Death

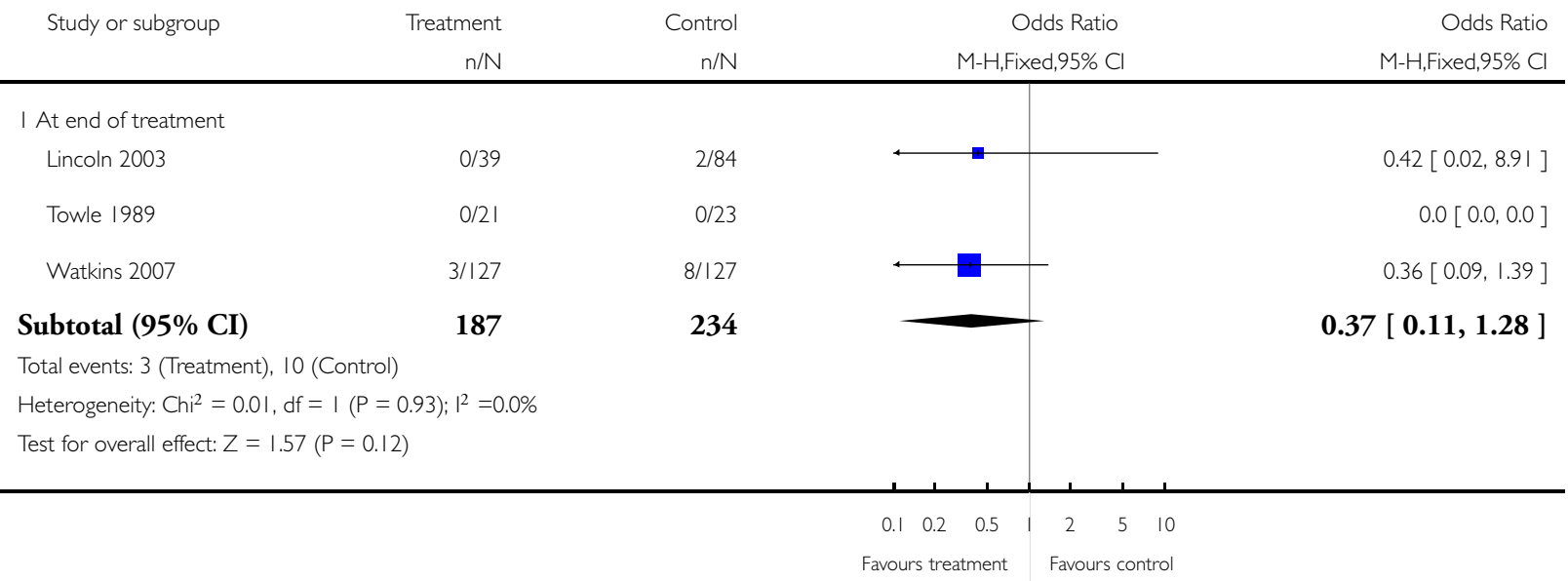


Analysis 3.9. Comparison 3 Psychological interventions versus standard care and/or attention control, Outcome 9 Adverse events: 2. All.

Review: Interventions for treating depression after stroke

Comparison: 3 Psychological interventions versus standard care and/or attention control

Outcome: 9 Adverse events: 2. All

\begin{tabular}{|c|c|c|c|c|c|}
\hline \multirow[t]{2}{*}{ Study or subgroup } & Treatment & Control & \multirow{2}{*}{$\begin{array}{r}\text { Odds Ratio } \\
\text { M-H,Fixed,95\% Cl }\end{array}$} & \multirow[t]{2}{*}{ Weight } & \multirow{2}{*}{$\begin{array}{r}\text { Odds Ratio } \\
\text { M-H,Fixed,95\% Cl } \\
\end{array}$} \\
\hline & $\mathrm{n} / \mathrm{N}$ & $\mathrm{n} / \mathrm{N}$ & & & \\
\hline \multicolumn{6}{|c|}{ I Protocol violation (e.g. refused treatment, withdrew consent) } \\
\hline Towle 1989 & $0 / 21$ & $1 / 22$ & & $100.0 \%$ & $0.33[0.01,8.65]$ \\
\hline Subtotal (95\% CI) & 21 & 22 & & $100.0 \%$ & $0.33[0.01,8.65]$ \\
\hline \multicolumn{6}{|c|}{ Total events: 0 (Treatment), I (Control) } \\
\hline \multicolumn{6}{|c|}{ Heterogeneity: not applicable } \\
\hline \multicolumn{6}{|c|}{ Test for overall effect: $Z=0.66(P=0.5 \mathrm{I})$} \\
\hline \multicolumn{6}{|c|}{2 Recurrent stroke } \\
\hline Watkins 2007 & $2 / 127$ & $0 / 127$ & & $100.0 \%$ & $5.08[0.24,106.87]$ \\
\hline Subtotal (95\% CI) & 127 & 127 & & $100.0 \%$ & $5.08[0.24,106.87]$ \\
\hline \multicolumn{6}{|c|}{ Total events: 2 (Treatment), 0 (Control) } \\
\hline \multicolumn{6}{|c|}{ Heterogeneity: not applicable } \\
\hline \multicolumn{6}{|c|}{ Test for overall effect: $Z=1.05(P=0.30)$} \\
\hline \multicolumn{6}{|c|}{3 Vascular events - not stroke (e.g. transient ischaemic attack) } \\
\hline Watkins 2007 & $5 / 127$ & $7 / 127$ & & $100.0 \%$ & $0.70[0.22,2.27]$ \\
\hline Subtotal (95\% CI) & 127 & 127 & & $100.0 \%$ & $0.70[0.22,2.27]$ \\
\hline \multicolumn{6}{|c|}{ Total events: 5 (Treatment), 7 (Control) } \\
\hline \multicolumn{6}{|c|}{ Heterogeneity: not applicable } \\
\hline \multicolumn{6}{|c|}{ Test for overall effect: $Z=0.59(P=0.56)$} \\
\hline
\end{tabular}




\section{Analysis 3.10. Comparison 3 Psychological interventions versus standard care and/or attention control, Outcome 10 Adverse events: 3. Leaving the study early (including death).}

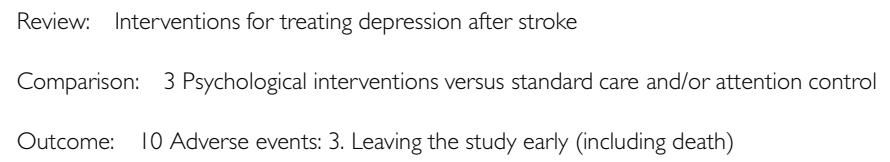

$\mathrm{n} / \mathrm{N} \quad \mathrm{n} / \mathrm{N}-\mathrm{H}$, Fixed,95\% Cl M-H,Fixed,95\% Cl

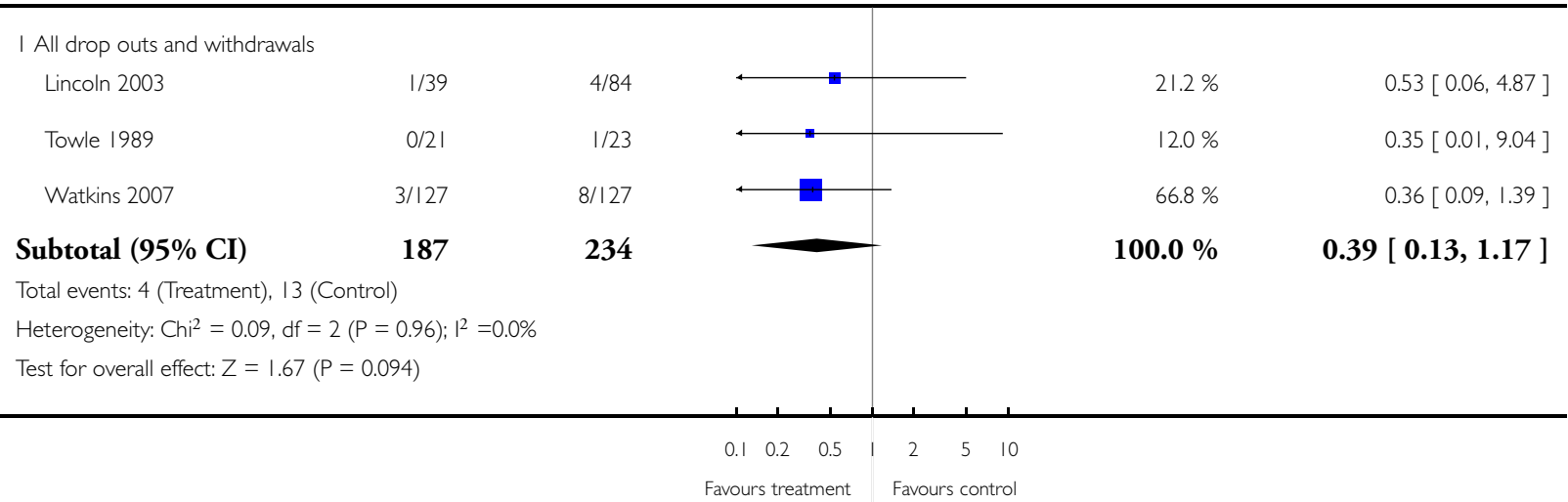

\section{ADDITIONAL TABLES}

Table 1. Characteristics of 'drop-out' studies

\begin{tabular}{|c|c|c|c|c|c|c|}
\hline Study ID & Methods & Participants & Interventions & Outcomes & Notes & Allocation \\
\hline $\begin{array}{l}\text { Choi-Kwon } \\
2006\end{array}$ & $\begin{array}{l}\text { Parallel design } \\
\text { Method of ran- } \\
\text { domisation: } \\
\text { computer- } \\
\text { generated list of } \\
\text { treatment num- } \\
\text { bers } \\
\text { Method of con- } \\
\text { cealment: } \\
\text { unclear } \\
\text { Blinding: } \\
\text { double blind } \\
\text { Particiapnts: yes } \\
\text { Investigators: } \\
\text { yes } \\
\text { Relatives: yes } \\
\text { Outcome asses- } \\
\text { sors: no }\end{array}$ & $\begin{array}{l}\text { Location: Seoul } \\
\text { Setting: } \\
\text { outpatients } \\
\text { Treat- } \\
\text { ment: } 76 \text { (75\% } \\
\text { male, mean age } \\
58 \text { years, SD 9) } \\
\text { Con- } \\
\text { trol: } 76 \text { (79\% } \\
\text { male, mean age } \\
58 \text { years, SD 9) } \\
\text { Stroke criteria: } \\
\text { ischaemic stroke; } \\
\text { diagnosis via CT } \\
\text { and MRI scans; } \\
\text { interview per- } \\
\text { formed on aver- } \\
\text { age of } 14 \text { months }\end{array}$ & $\begin{array}{l}\text { Treatment: flu- } \\
\text { oxetine } 20 \mathrm{mg} \\
\text { daily } \\
\text { Control: } \\
\text { matched } \\
\text { placebo } \\
\text { Duration: treat- } \\
\text { ment continued } \\
\text { for } 3 \text { months }\end{array}$ & $\begin{array}{l}\text { Depression: } \\
\text { change in scores } \\
\text { from baseline to } \\
\text { end of treatment } \\
\text { and end of follow } \\
\text { up on BDI } \\
\text { Additional: leav- } \\
\text { ing the } \\
\text { study early, ad- } \\
\text { verse events } \\
\text { Unable to use: } \\
\text { outcome data } \\
\text { not presented in } \\
\text { a format suitable } \\
\text { for this review }\end{array}$ & $\begin{array}{l}\text { Exclusion crite- } \\
\text { ria: } \\
\text { did not undergo } \\
\text { imaging (CT/ } \\
\text { MRI) studies, } \\
\text { SAH, had TIA } \\
\text { without progres- } \\
\text { sion to stroke, } \\
\text { severe communi- } \\
\text { cation problems } \\
\text { (aphasia, demen- } \\
\text { tia, or dysarthria, } \\
\text { scored < } 23 \text { on } \\
\text { MMSE, history } \\
\text { of depression } \\
\text { or psychiatric ill- }\end{array}$ & A \\
\hline
\end{tabular}




\begin{tabular}{|c|c|c|c|c|c|c|}
\hline & $\begin{array}{l}\text { Analysis: } \\
\text { ITT: } \\
27 \text { withdrew be- } \\
\text { fore com- } \\
\text { pleting 3-month } \\
\text { treatment proto- } \\
\text { col, with- } \\
\text { drew due to pro- } \\
\text { tocol violation (4 } \\
\text { treatment, } \\
6 \text { control), with- } \\
\text { drew due to AE } \\
\text { (10 treatment, } 2 \\
\text { control), } \\
\text { withdrawn } \\
\text { due to readmis- } \\
\text { sion into hos- } \\
\text { pital because of } \\
\text { other diseases (1 } \\
\text { treatment, } \\
2 \text { control), with- } \\
\text { drew due to be- } \\
\text { lieving treatment } \\
\text { was not effective } \\
\text { ( } 2 \text { control) }\end{array}$ & $\begin{array}{l}\text { after stroke } \\
\text { De- } \\
\text { pression criteria: } \\
\text { psychiatric inter- } \\
\text { view, BDI score } \\
>13 \\
\text { Other en- } \\
\text { try criteria: none } \\
\text { stated } \\
\text { Comparabil- } \\
\text { ity of treatment } \\
\text { groups: non-sig- } \\
\text { nificant trend to- } \\
\text { wards right- } \\
\text { sided lesion } \\
\text { strokes in con- } \\
\text { trol group and } \\
\text { left-sided lesion } \\
\text { strokes in treat- } \\
\text { ment group }\end{array}$ & & & $\begin{array}{l}\text { ness before onset } \\
\text { of stroke, already } \\
\text { treated with psy- } \\
\text { chiatric regi- } \\
\text { mens, lived alone }\end{array}$ & \\
\hline Downes 1995 & $\begin{array}{l}\text { Parallel design } \\
\text { Method of ran- } \\
\text { domisation: ran- } \\
\text { dom number se- } \\
\text { quence stratified } \\
\text { by Rankin score } \\
\text { Method of con- } \\
\text { cealment: ran- } \\
\text { domised by one } \\
\text { of the authors } \\
\text { Blinding: single } \\
\text { blind } \\
\text { Participants: no } \\
\text { Investigators: no } \\
\text { Outcome asses- } \\
\text { sors: yes } \\
\text { Analy- } \\
\text { sis: per protocol: } \\
105 \text { participants } \\
\text { randomised, } 87 \\
\text { available } \\
\text { at } 6 \text { months, } 18 \\
\text { lost to follow up }\end{array}$ & $\begin{array}{l}\text { Location: UK } \\
\text { Setting: } \\
\text { outpatient } \\
\text { Treatment 1: } 22 \\
\text { (50\% male, age } \\
\text { not reported) } \\
\text { Treatment 2: } 22 \\
\text { (55\% male, age } \\
\text { not reported) } \\
\text { Control: } 18 \\
\text { ( } 44 \% \text { male, age } \\
\text { not reported) } \\
\text { Stroke criteria: } \\
\text { unclear; no cri- } \\
\text { teria defined in } \\
\text { study for time } \\
\text { from stroke to } \\
\text { randomisation } \\
\text { Other entry cri- } \\
\text { teria: } \\
\text { lived at home, } \\
\text { had an informal } \\
\text { carer, stroke in- }\end{array}$ & $\begin{array}{l}\text { Treatment 1: in- } \\
\text { formation } \\
\text { plus counselling. } \\
\text { Egan's } \\
\text { problem solving } \\
\text { approach, indi- } \\
\text { vidual is helped } \\
\text { to explore con- } \\
\text { cerns, clar- } \\
\text { ify problems, set } \\
\text { goal and take ap- } \\
\text { propriate action. } \\
\text { Protocol dis- } \\
\text { cussed first and } \\
\text { formulated into } \\
\text { a coun- } \\
\text { sellor/client con- } \\
\text { tract. Informa- } \\
\text { tion pack con- } \\
\text { taining informa- } \\
\text { tion on physical, } \\
\text { cognitive, }\end{array}$ & $\begin{array}{l}\text { Depression: } \\
\text { change in scores } \\
\text { from baseline to } \\
\text { end of treatment } \\
\text { on HADS } \\
\text { Ad- } \\
\text { ditional: HADS } \\
\text { anxiety score } \\
\text { Unable to use: all } \\
\text { data } \\
\text { presented com- } \\
\text { bines both de- } \\
\text { pressed and non- } \\
\text { depressed partic- } \\
\text { ipants at baseline }\end{array}$ & $\begin{array}{l}\text { Exclusion crite- } \\
\text { ria: not living at } \\
\text { home, not hav- } \\
\text { ing an informal } \\
\text { carer, having no } \\
\text { increase in dis- } \\
\text { ability or change } \\
\text { in lifestyle/ } \\
\text { dependency }\end{array}$ & B \\
\hline
\end{tabular}


Table 1. Characteristics of 'drop-out' studies (Continued)

\begin{tabular}{|c|c|c|c|c|c|c|}
\hline & $\begin{array}{l}\text { (no reason given) } \\
, 25 \text { not assessed } \\
\text { (no reason given) } \\
, \quad 43 \text { excluded } \\
\text { from analysis }\end{array}$ & $\begin{array}{l}\text { crease mRS, } \\
\text { post-stroke mRS } \\
\text { score of } 2 \text { to } 5 \\
\text { Comparabil- } \\
\text { ity of treatment } \\
\text { groups: balanced }\end{array}$ & $\begin{array}{l}\text { behavioural and } \\
\text { emotional effects } \\
\text { of stroke, carer } \\
\text { well-being, and } \\
\text { local services. } \\
\text { Treatment 2: in- } \\
\text { formation only: } \\
\text { informa- } \\
\text { tion pack con- } \\
\text { taining informa- } \\
\text { tion on physical, } \\
\text { cognitive, } \\
\text { behavioural and } \\
\text { emotional effects } \\
\text { of stroke, carer } \\
\text { well-being, and } \\
\text { local services. } \\
\text { Control: } \\
\text { standard care, no } \\
\text { visit(s) or infor- } \\
\text { mation pack pro- } \\
\text { vided } \\
\text { Duration: infor- } \\
\text { mation ses- } \\
\text { sion consisted of } \\
1 \text { visit and pro- } \\
\text { vision of the in- } \\
\text { formation pack } \\
\text { Counselling } \\
\text { consisted of up } \\
\text { to } 8 \text { counselling } \\
\text { sessions over } 4 \text { to } \\
6 \text { months } \\
\text { Delivered by: } \\
\text { nurse counsellor }\end{array}$ & & & \\
\hline $\begin{array}{l}\text { Graffagnino } \\
2003\end{array}$ & $\begin{array}{l}\text { Parallel design } \\
\text { Method of ran- } \\
\text { domisation: un- } \\
\text { clear } \\
\text { Method of con- } \\
\text { cealment: } \\
\text { unclear } \\
\text { Blinding: } \\
\text { unclear } \\
\text { Analysis: unclear }\end{array}$ & $\begin{array}{l}\text { Location: } \\
\text { unclear } \\
\text { Setting: unclear } \\
\text { Treatment: un- } \\
\text { clear } \\
\text { Control: unclear } \\
\text { Stroke criteria: } \\
\text { unclear } \\
\text { Depression cri- } \\
\text { teria: unclear } \\
\text { Other entry cri- } \\
\text { teria: unclear } \\
\text { Comparabil- }\end{array}$ & $\begin{array}{l}\text { Treatment: ser- } \\
\text { traline } \\
\text { Control: } \\
\text { matched } \\
\text { placebo } \\
\text { Duration: } \\
\text { unclear }\end{array}$ & $\begin{array}{l}\text { Depression: un- } \\
\text { clear } \\
\text { Additional: un- } \\
\text { clear } \\
\text { Unable to } \\
\text { use: no data pre- } \\
\text { sented }\end{array}$ & $\begin{array}{l}\text { Exclusion crite- } \\
\text { ria: unclear }\end{array}$ & B \\
\hline
\end{tabular}


Table 1. Characteristics of 'drop-out' studies (Continued)

\begin{tabular}{|c|c|c|c|c|c|c|}
\hline & & $\begin{array}{l}\text { ity of treatment } \\
\text { groups: unclear }\end{array}$ & & & & \\
\hline Isenberg 2000 & $\begin{array}{l}\text { Parallel design } \\
\text { Method of ran- } \\
\text { domisation: un- } \\
\text { clear } \\
\text { Method of con- } \\
\text { cealment: } \\
\text { unclear } \\
\text { Blinding: double } \\
\text { blind }\end{array}$ & $\begin{array}{l}\text { Location: } \\
\text { unclear } \\
\text { Setting: unclear } \\
\text { Treatment: } \\
\text { nefiracetam } \\
\text { Control: unclear } \\
\text { Stroke criteria: } \\
\text { unclear } \\
\text { Depression cri- } \\
\text { teria: unclear } \\
\text { Other entry cri- } \\
\text { teria: par- } \\
\text { ticipants must be } \\
\text { at least } 3 \text { months } \\
\text { poststroke } \\
\text { Comparabil- } \\
\text { ity of treatment } \\
\text { groups: unclear }\end{array}$ & $\begin{array}{l}\text { Treatment: } \\
\text { nefiracetam } \\
\text { Control: } \\
\text { matched } \\
\text { placebo } \\
\text { Duration: } \\
\text { unclear }\end{array}$ & $\begin{array}{l}\text { Depression: un- } \\
\text { clear } \\
\text { Additional: un- } \\
\text { clear } \\
\text { Unable to use: } \\
\text { no results avail- } \\
\text { able }\end{array}$ & $\begin{array}{l}\text { Exclusion crite- } \\
\text { ria: unclear }\end{array}$ & B \\
\hline Mauri 1988 & $\begin{array}{l}\text { Parallel design } \\
\text { Method of ran- } \\
\text { domisation: un- } \\
\text { clear } \\
\text { Method of con- } \\
\text { cealment: } \\
\text { unclear } \\
\text { Blinding: } \\
\text { unclear } \\
\text { Analysis: unclear }\end{array}$ & $\begin{array}{l}\text { Location: Spain } \\
\text { Setting: unclear } \\
\text { Treatment: mi- } \\
\text { anserin, } 6 \text { weeks, } \\
\text { dose unclear } \\
\text { Control: } \\
\text { placebo } \\
\text { Stroke cri- } \\
\text { teria: ischaemic } \\
\text { stroke, diagnosis } \\
\text { unclear; stroke } 6 \\
\text { months prior to } \\
\text { randomisation } \\
\text { Depression cri- } \\
\text { teria: GDS (15 } \\
\text { item) score > } 4 \\
\text { Other } \\
\text { try criteria: none } \\
\text { stated } \\
\text { Comparabil- } \\
\text { ity of treatment } \\
\text { groups: unclear }\end{array}$ & $\begin{array}{l}\text { Treatment: mi- } \\
\text { anserin } \\
\text { Control: } \\
\text { placebo } \\
\text { Duration: treat- } \\
\text { ment continued } \\
\text { for } 6 \text { weeks }\end{array}$ & $\begin{array}{l}\text { Depression: un- } \\
\text { clear } \\
\text { Additional: un- } \\
\text { clear } \\
\text { Unable to use: } \\
\text { results not avail- } \\
\text { able in format } \\
\text { suitable for this } \\
\text { review }\end{array}$ & $\begin{array}{l}\text { Exclusion crite- } \\
\text { ria: unclear }\end{array}$ & B \\
\hline Meara 1998 & $\begin{array}{l}\text { Parallel design } \\
\text { Method of ran- } \\
\text { domisation: un- } \\
\text { clear }\end{array}$ & $\begin{array}{l}\text { Location: Wales, } \\
\text { UK } \\
\text { Setting: } \\
\text { inpatient }\end{array}$ & $\begin{array}{ll}\text { Treatment: } & \text { ser- } \\
\text { traline, } 50 & \mathrm{mg} \text {, } \\
\text { daily } & \\
\text { Dose } & \text { esca- }\end{array}$ & $\begin{array}{l}\text { Depression: } \\
\text { change in scores } \\
\text { from baseline to } \\
\text { end of treatment }\end{array}$ & $\begin{array}{l}\text { Exclusion crite- } \\
\text { ria: moderate to } \\
\text { severe dementia, } \\
\text { severe aphasia, }\end{array}$ & B \\
\hline
\end{tabular}


Table 1. Characteristics of 'drop-out' studies (Continued)

\begin{tabular}{|c|c|c|c|c|c|c|}
\hline & $\begin{array}{l}\text { Method of con- } \\
\text { cealment: } \\
\text { unclear } \\
\text { Blinding: double } \\
\text { blind reported, } \\
\text { those blinded } \\
\text { not stated } \\
\text { Analysis: unclear }\end{array}$ & $\begin{array}{l}\text { Treatment: un- } \\
\text { clear } \\
\text { Control: unclear } \\
\text { Stroke cri- } \\
\text { teria: ischaemic } \\
\text { stroke, diagnosis } \\
\text { unclear; stroke > } \\
11 \text { weeks prior to } \\
\text { randomisation } \\
\text { Depression cri- } \\
\text { teria: GDS (15 } \\
\text { item) score > } 4 \\
\text { Other en- } \\
\text { try criteria: none } \\
\text { stated } \\
\text { Comparabil- } \\
\text { ity of treatment } \\
\text { groups: balanced }\end{array}$ & $\begin{array}{l}\text { lation to } 100 \mathrm{mg} \\
\text { for non-respon- } \\
\text { ders at } 2 \text { weeks } \\
\text { Control: } \\
\text { matched } \\
\text { placebo } \\
\text { Duration: treat- } \\
\text { ment continued } \\
\text { for } 6 \text { weeks }\end{array}$ & $\begin{array}{l}\text { on GDS } \\
\text { Unable to use: } \\
\text { GDS, } \\
\text { BI, MMSE, FAI, } \\
\text { FAST, } \\
\text { leaving the study } \\
\text { early, death (data } \\
\text { not presented) } \\
\text { Ad- } \\
\text { verse events (data } \\
\text { not presented by } \\
\text { treatment group, } \\
9 \text { patients devel- } \\
\text { oped side effects, } \\
\text { generally mild } \\
\text { and transient) }\end{array}$ & $\begin{array}{l}\text { commu- } \\
\text { nication difficul- } \\
\text { ties, poorly con- } \\
\text { trolled epilepsy }\end{array}$ & \\
\hline Ohtomo 1985 & $\begin{array}{l}\text { Parallel design } \\
\text { Method of ran- } \\
\text { domisation: un- } \\
\text { clear } \\
\text { Method of con- } \\
\text { cealment: } \\
\text { unclear } \\
\text { Blinding: double } \\
\text { bind reported, } \\
\text { those blinded } \\
\text { not stated } \\
\text { Anal- } \\
\text { ysis: per proto- } \\
\text { col: protocol vio- } \\
\text { lation (1 control) } \\
\text {, excluded from } \\
\text { analysis }\end{array}$ & $\begin{array}{l}\text { Location: Japan } \\
\text { Setting: unclear } \\
\text { Treatment: } 141 \\
(54 \% \text { male, age } \\
\text { details unclear) } \\
\text { Control: } 147 \\
\text { (61\% male, age } \\
\text { details unclear) } \\
\text { Stroke } \\
\text { criteria: all sub- } \\
\text { types; diagnosis } \\
\text { via clinical signs } \\
\text { and CT (\% not } \\
\text { reported); time } \\
\text { from stroke to } \\
\text { randomisation } \\
\text { not reported } \\
\text { Other } \\
\text { try criteria: }>40 \\
\text { years of age, high } \\
\text { blood pressure (> } \\
160 / 90 \text { mmHg) } \\
\text { and hypertensive } \\
\text { changes on fun- } \\
\text { doscopy } \\
\text { changes, stable } \\
\text { Neuroleptic, mi- } \\
\text { nor tranquilliser, } \\
\text { antidepressant, }\end{array}$ & $\begin{array}{l}\text { Treatment: } \\
\text { tiapride, } \\
75 \text { mg daily for } 1 \\
\text { week, dose esca- } \\
\text { lation to } 150 \text { to } \\
225 \text { mg daily for } \\
5 \text { weeks accord- } \\
\text { ing to clinical re- } \\
\text { sponse } \\
\text { Control: } \\
\text { matched } \\
\text { placebo } \\
\text { Duration: treat- } \\
\text { ment continued } \\
\text { for } 6 \text { weeks }\end{array}$ & $\begin{array}{l}\text { Depression: un- } \\
\text { clear } \\
\text { Unable to } \\
\text { use: no data pre- } \\
\text { sented by } \\
\text { 'not depressed at } \\
\text { baseline' }\end{array}$ & $\begin{array}{l}\text { Exclusion crite- } \\
\text { ria: severe apha- } \\
\text { sia, severe de- } \\
\text { mentia, drug de- } \\
\text { pendence, inade- } \\
\text { quate conditions } \\
\text { for the study }\end{array}$ & B \\
\hline
\end{tabular}


Table 1. Characteristics of 'drop-out' studies (Continued)

\begin{tabular}{|c|c|c|c|c|c|c|}
\hline & & $\begin{array}{l}\text { brain metabolic } \\
\text { activators, cere- } \\
\text { bro-vasodilators } \\
\text { washed out for } 3 \\
\text { to } 7 \text { days prior to } \\
\text { randomisation } \\
\text { Comparabil- } \\
\text { ity of treatment } \\
\text { groups: balanced }\end{array}$ & & & & \\
\hline Xie 2003 & $\begin{array}{l}\text { Parallel design } \\
\text { Method of ran- } \\
\text { domisation: un- } \\
\text { clear, 'paired' } \\
\text { Method of con- } \\
\text { cealment: } \\
\text { unclear } \\
\text { Blinding: } \\
\text { unclear } \\
\text { Analysis: unclear }\end{array}$ & $\begin{array}{l}\text { Location: China } \\
\text { Setting: unclear } \\
\text { Treatment: } \\
41 \text { (\% male un- } \\
\text { clear, mean age } \\
64 \text { years SD 7) } \\
\text { Control: } \\
41 \text { (\% male un- } \\
\text { clear, mean age } \\
62 \text { years SD 5) } \\
\text { Stroke criteria: } \\
\text { infarction and } \\
\text { cerebral haemor- } \\
\text { rhage; time from } \\
\text { stroke to ran- } \\
\text { domisation not } \\
\text { reported } \\
\text { Other entry cri- } \\
\text { te- } \\
\text { ria: hemiplegia, } \\
\text { admitted during } \\
\text { January } 1988 \text { to } \\
\text { July } 2002 \\
\text { Comparabil- } \\
\text { ity of treatment } \\
\text { groups: balanced }\end{array}$ & $\begin{array}{l}\text { Treatment: psy- } \\
\text { chological inter- } \\
\text { vention: feeling } \\
\text { support therapy, } \\
\text { recognition ther- } \\
\text { apy, collec- } \\
\text { tive therapy, so- } \\
\text { cial support and } \\
\text { skills train- } \\
\text { ing, plus rou- } \\
\text { tine drug treat- } \\
\text { ment and reha- } \\
\text { bilitation train- } \\
\text { ing } \\
\text { Control: routine } \\
\text { drug treat- } \\
\text { ment and reha- } \\
\text { bilitation train- } \\
\text { ing } \\
\text { Duration: } \\
\text { unclear } \\
\text { Delivered by: } \\
\text { unclear }\end{array}$ & $\begin{array}{l}\text { Depression: end- } \\
\text { point but } \\
\text { method of assess- } \\
\text { ment unclear } \\
\text { Additional: } \\
\text { panic, anxiety, } \\
\text { stubborn, hostil- } \\
\text { ity } \\
\text { Unable to use: } \\
\text { Method of as- } \\
\text { sessment } \\
\text { not clear, SCL- } \\
90 \\
\text { but outcomes re- } \\
\text { ported are differ- } \\
\text { ent }\end{array}$ & $\begin{array}{l}\text { Exclusion crite- } \\
\text { ria: unclear }\end{array}$ & B \\
\hline Zhou 2004 & $\begin{array}{l}\text { Parallel design } \\
\text { Method of ran- } \\
\text { domisation: } \\
\text { unclear, 'equally } \\
\text { randomised' } \\
\text { Method of con- } \\
\text { cealment: } \\
\text { unclear } \\
\text { Blinding: } \\
\text { unclear } \\
\text { Analysis: unclear }\end{array}$ & $\begin{array}{l}\text { Location: China } \\
\text { Setting: unclear } \\
\text { Treat- } \\
\text { ment: } 50 \quad(56 \% \\
\text { male, mean age } \\
63.8 \text { years) } \\
\text { Control: } \\
50 \text { (60\% male, } \\
\text { mean age } 65.4 \\
\text { years) } \\
\text { Stroke crite- } \\
\text { ria: unclear; time }\end{array}$ & $\begin{array}{l}\text { Treatment: reha- } \\
\text { bilitation } \\
\text { therapy plus psy- } \\
\text { chological nurs- } \\
\text { ing strategy in- } \\
\text { volv- } \\
\text { ing many people } \\
\text { including carers } \\
\text { and a buddy sys- } \\
\text { tem } \\
\text { Control: rehabil- } \\
\text { itation therapy }\end{array}$ & $\begin{array}{l}\text { Depression: } \\
\text { multimodal ap- } \\
\text { proach to diag- } \\
\text { nosis, Beck De- } \\
\text { pression Inven- } \\
\text { tory, HDRS } \\
\text { Ad- } \\
\text { ditional: physical } \\
\text { function }\end{array}$ & $\begin{array}{l}\text { Exclusion crite- } \\
\text { ria: unclear }\end{array}$ & B \\
\hline
\end{tabular}


Table 1. Characteristics of 'drop-out' studies (Continued)

\begin{tabular}{l|lr} 
from stroke to & $\begin{array}{l}\text { Duration: } \\
\text { randomisation }\end{array}$ & 6 \\
weeks & \\
not reported & Delivered & by: \\
Other entry cri- & unclear & \\
teria: unclear & \\
Comparabil- & \\
ity of treatment & \\
groups: unclear &
\end{tabular}

AE: adverse event(s)

BDI: Beck Depression Inventory

CT: computed tomography

BI: Barthel Index

FAI: Frenchay Activities Index

FAST: Frenchay Aphasia Screening Test

GDS: Geriatric Depression Scale

HADS: Hospital Anxiety and Depression Scale

HDRS: Hamilton Depression Rating Scale

ITT: intention to treat

MMSE: Mini-Mental State Examination

MRI: magnetic resonance imaging

mRS: modified Rankin Scale

SAH: subarachnoid haemorrhage

TIA: transient ischaemic attack

\section{A P P E N D I C E S}

\section{Appendix I. MEDLINE search strategy}

We used the following search strategy using a combination of controlled vocabulary and free text terms for MEDLINE and CINAHL (Ovid), and modified it to suit the other databases.

1 exp cerebrovascular disorders/

2 (stroke $\$$ or poststroke $\$$ or cva $\$$ ).tw.

3 (cerebrovascular\$ or cerebral vascular).tw.

4 (cerebral or cerebellar or brain $\$$ or vertebrobasilar).tw.

5 (infarct\$ or isch?emi $\$$ or thrombo $\$$ or emboli\$ or apoplexy).tw.

6 (cerebral or intracerebral or intracranial or brain\$).tw.

7 (haemorrhage or hemorrhage or bleed\$).tw.

84 and 5

96 and 7

101 or 2 or 3 or 8 or 9

11 Depression/

12 Depression, involutional/ or Depressive disorder/ or Dysthymic disorder/

13 (depress\$ or dysthymi\$).tw.

1411 or 12 or 13

Interventions for treating depression after stroke (Review)

Copyright $\odot 2008$ The Cochrane Collaboration. Published by John Wiley \& Sons, Ltd. 
1510 and 14

16 randomized controlled trial.pt.

17 randomized controlled trials/

18 controlled clinical trial.pt.

19 controlled clinical trials/

20 random allocation/

21 double-blind method/

22 single-blind method/

23 clinical trial.pt.

24 exp clinical trials/

25 (clin\$ adj25 trial\$).tw.

26 ((singl\$ or doubl\$ or tripl\$ or trebl\$) adj25 (blind\$ or mask\$)).tw.

27 placebos/

28 placebo $\$$.tw.

29 random\$.tw.

30 research design/

31 clinical trial phase ii.pt.

32 clinical trial phase iii.pt.

33 clinical trial phase iv.pt.

34 meta analysis.pt.

35 multicenter study.pt.

36 intervention studies/

37 cross-over studies/

38 meta-analysis/

39 control\$.tw.

40 alternate treatment.tw.

41 "comparative study"/

42 exp evaluation studies/

43 Follow-up studies/

44 Prospective studies/

45 prospective.tw.

46 (versus or sham or intervention group or comparative stud\$).tw.

47 or/ $16-46$

4815 and 47

49 limit 48 to human

\section{WHAT'S NEW}

Last assessed as up-to-date: 25 May 2008.

\begin{tabular}{|c|c|c|}
\hline Date & Event & Description \\
\hline 28 March 2008 & Amended & Converted to new review format. \\
\hline 14 March 2008 & New search has been performed & $\begin{array}{l}\text { The searches for the review were completed to February } \\
2008 . \\
\text { Seven new trials have been added: six pharmacological in- } \\
\text { terventions making a total of } 13 \text {, and two psychological } \\
\text { interventions making a total of four comparisons. There } \\
\text { are now } 16 \text { included trials with } 1655 \text { participants }\end{array}$ \\
\hline
\end{tabular}

Interventions for treating depression after stroke (Review)

Copyright (@) 2008 The Cochrane Collaboration. Published by John Wiley \& Sons, Ltd. 
Eight trials require more information before they can be assessed for inclusion in the review (down from 14 in the previous version). Nine trials appear to meet the review inclusion criteria but information is not available in a format suitable for pooling. Three studies are ongoing (up from 0 in the previous version)

14 March 2008 New citation required and conclusions have changed

This version of the review found a small but significant effect of pharmacotherapy (not psychotherapy) on treating depression and reducing depressive symptoms in stroke patients

There has also been a change of authorship.

\section{H I S T O R Y}

Protocol first published: Issue 1, 2002

Review first published: Issue 3, 2004

\section{CONTRIBUTIONS OF AUTHORS}

The first three review authors had equal input into the development, writing, and editing of the protocol and undertook the work necessary to complete the review. JX assisted with obtaining and translating and extracting data from Chinese studies for the updated review. The update was completed by $\mathrm{MH}$.

\section{DECLARATIONS OF INTEREST}

None known

\section{SOURCES OF SUPPORT}

\section{Internal sources}

- The George Institute for International Health, Australia. 


\section{External sources}

- Stroke Society of Australasia, Overseas Study Scholarship, Australia.

- The Academic Unit of Psychiatry, The University of Leeds, UK.

- The Department of Clinical Neurosciences, The University of Edinburgh, UK.

- The Clinical Trials Research Unit, The University of Auckland, New Zealand.

\section{NDEX TERMS}

\section{Medical Subject Headings (MeSH)}

Antidepressive Agents [adverse effects; therapeutic use]; Anxiety [chemically induced]; Depression [*therapy]; Psychotherapy; Randomized Controlled Trials as Topic; Stroke [* psychology]

\section{MeSH check words}

Humans 